\title{
PLASMÍDIOS CONJUGATIVOS E FUSÃO DE PROTOPLASTOS EM
}

Streptomyces felleus

\author{
JANETE MAGALI DE ARAÚJO \\ Bióloga
}

Orientador: Prof. Dr. JOÃO LÚCIO DE AZEVEDO

\begin{abstract}
Tese apresentada à Escola superior de Agricultura "Luiz de Queiroz", da Universidade de são Paulo, para obtenção do titulo de Doutor em Agronomia. Área de concentração: Genética e Melhoramento de Plantas.
\end{abstract}

PIRACICABA

Estado de São Paulo - Brasil

Setembro - 1990 
Ficha catalográfica preparada pela Seção de Livros da Divisão de Biblioteca e Documentação - PCAP/USP

Araújo, Janete Magali de

A663p Plasmídios conjugativos e fusăo de protoplastos em Streptomyces felleus. Piracicaba, 1990.

$178 p$.

Tese - ESALQ

Bibliografia.

1. Bactéria Gram-positiva 2. Fusăo de protoplasto 3. Plasmidio conjugativo I. Escola Superior de Agricultura Luiz de Queiroz, Piracicaba

CDD $\quad 589.9$ 


\section{PlASMÍDIOS CONJUGATIVOS E FUSÃo DE PROTOPLASTOS EM}

Streptomyces felleus

JANETE MAGALI DE ARAÚJO

Aprovada em 13/11/1990

Comissão Julgadora:

Prof. Dr. João Lúcio de Azevedo

ESALQ/USP

Prof. Dr. Sérgio Olavo Pinto da Costa

IB/USP

Prof. Dr. Gabriel Padilha

Prof. Dr. José Otamar Falcão de Moraes

ICB/USP

Profa Dra Yoko Bomura Rosato

UFPE

UNICAMP

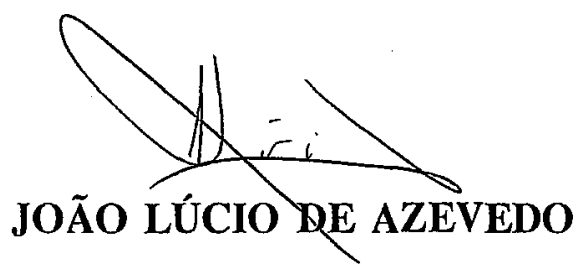

-Orientador- 
"In memoriam"

ofereço

ao Prof. Oswaldo Gonçalves de Lima

e so meu irmão Juarez

A minha família, ea especial minha mãe e a. Jorginho 
AGRADECIMENTOS

Ao Prof. Dr. João Lúcio de Azevedo, por sua valiosa compreensão, amizade e orientação.

Ao Prof. Dr. Wlodzimierz Kurylowicz, pela alegria de ter recebido os primeiros ensinamentos me incentivando e induzindo a abraçar esta área de pesquisa.

Ao Prof. José Otamar Falcão de Morais por sua amizade e imprescindíveis sugestões na correção deste trabalho.

Ao Departamento de Antibióticos da Universidade Federal de Pernambuco nas pessoas de seus ex-chefes Prof. Francisco Dácio de Andrade Lyra à Profa. Dra. Suely Galdino pela compreensão e pelo apoilo oferecido no desenvolvimento deste trabalho.

Aos "amigos do Laboratóxio de Biologia Molecular da Universidade de Brasília na pessoa do Prof. Dr. Spartaco Astolfi Filho pela amizade e pelo apoio na realização das eletroforeses de DNA plamidial.

Ao Prof. Dr. Kazutaka Fukushima Chiba University - Japão pela purificação caracterização do antifúngico constante neste trabalho. 
A Profa. Dra. Luzia Paccola-Meirelles pela convivência amiga, companheirismo e imprescindíveis sugestões.

A CAPES PICD, pelo apoio financeiro recebido.

Aos amigos do Departamento de Antibióticos na pessoa da Profa. Eugênia Maria Maranhão Rios pelo apoio constanté e amizade.

A Profa. Berenilda Ramalho de Mello pela amizade, compreensão e ajuda imprescindível, bem como pela correção, revisão gramatical e serviços de computação.

A todos os amigos do Laboratório de Genética de Microrganismos, em especial Edison Neiroti, Eleonora R. Carmona, Eduardo Bagalhi e Maria José Valarini pelo companheirismo.

Aos Srs. Antonio Rocha Campos, Sandra E. Rocha Campos e Carlos Alberto Nolasco, pelos serviços técnicos prestados no decorrer deste trabalho.

Aos Drs. Aline P. Kleiner, Itamar Soares de Melo e Beatriz Mendes pela alegria do convívio amigo.

A Bibliotecária Nilce T. Purga e Sra: Terezinha de Jesus L. Barreto pela normatização da Bibliografia e eficiente atendimento. 
A estes e a todos aqueles que direta ou indiretamente colaboraram na realização deste trabalho desejo expressar os meus sinceros agradecimentos. 
SUMARIO

Página

RESUMO .................................. xiv

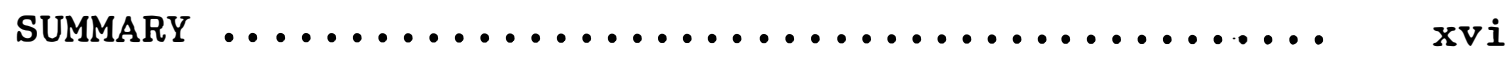

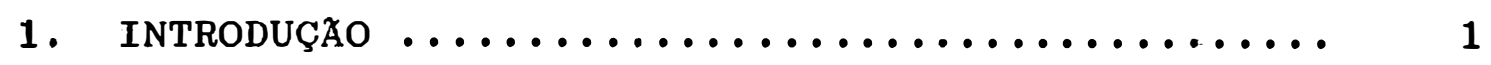

2. REVISAO DE LITERATURA ...................... 4

2.1. Actinomycetales: características gerais ... 4

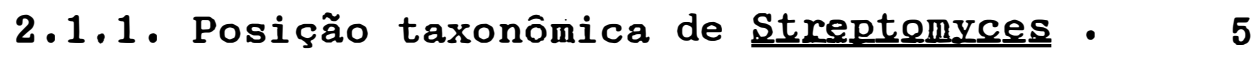

2.2. Genética de streptomyces ................ 10

2.2.1. Estrutura genômica .............. 11

2.2.2. Complexidade genômica ............ 13

2.2.3. Ocorrência de plasmídios ......... 15

2.2.3.1. Transferềncia de plasmídios .................... 17

2.2 .3 .2 .Zigose letal ........... 19

2.3. Produção de antibióticos ............... 20

2.3.1. Importância de streptomyces na produção de antibióticos .......... 21

2.3.2. Genética da produção de antibióti-

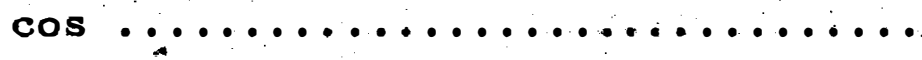

2.3.2.1. Papel dos plasmídios na produção de antibióticos ..

2.4. Novos métodos para obtenção de antibióti-

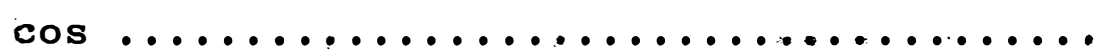

2.4.1. Fusão de protoplastos ............ 30

2.4.2. Tecnologia do DNA recombinante .... 34 
Página

3. MAterial E MEtodos $\ldots \ldots \ldots \ldots \ldots \ldots \ldots \ldots \ldots \ldots \ldots . \ldots \ldots$

3.1. Linhagens utilizadas $\ldots \ldots \ldots \ldots \ldots \ldots \ldots . \ldots . \ldots$

3.2. Meios de cultura. ................ 39

3.2.1. Meio de esporulação ........... 39

3.2.2. Meio mínimo .............. 39

3.2.3. Meio completo sólido .......... 39

3.2.4. Meio nutriente-ágar .......... 40

3.2.5. Meio "tryptic soya broth" (TSB) ... 40

3.2.6. Meio de Sabouraud ............ 40

3.2.7. Meio R2 YE ................ 40

3.2.8. Meio semi-sólido (overlay) ....... 41

3.2.9: Meio ISP1 - Triptona-extrato de levedura $\ldots \ldots \ldots \ldots \ldots \ldots \ldots \ldots \ldots . \ldots 41$

3.2.10. Meio ISP2 - Extrato de leveduraextrato de malte-ágar ......... 41

3.2.11. Meio ISP3 - Aveia-ágar ......... 42

3.2.12. Meio ISP4 - Amido-sais mineraiságar $\ldots \ldots \ldots \ldots \ldots \ldots \ldots \ldots \ldots \ldots, 42$

3.2.13. Meio- ISP5 - Glicerol-asparaginaágar ................... 42

3.2.14. Meio ISP6 - Peptona-extrato de levedura-ferro-ágar .......... 42

3.2.15. Meio ISP7 - Tirosina-ágar ...... 43

3.2.16. Meio ISP9 - Para fontes de carbono 43 
Página

3.2.17. Meio de tolerância a cloreto de sódio $\ldots \ldots \ldots \ldots \ldots \ldots \ldots \ldots \ldots \ldots$

3.2.18. Meio de gelatina-ágar .......... 44

3.2.19. Meio de produção de antibiótico ... 44

3.2.20. Esterilização dos meios ......... 44

3.3. Soluções utilizadas ................. 44

3.3.1. Soluções de vitaminas .......... 44

3 3.2. Solução de caseína hidrolisada .... 45

3.3.3. Solução de ácido nucleico ....... 45

3.3.4. Soluções-estoque dos suplementos adicionados ao meio mínimo ...... 46

3.3.5: Solução-estoque de acrilamida .... 46

3.3.6. Solução reveladora da atividade esterase $\ldots \ldots \ldots \ldots \ldots \ldots \ldots \ldots . \ldots 46$

3.3.7. Solução fixadora PAGE ......... 47

3.3.8. Solução de glicina (20\%) ........ 47

3.3.9. Solução de sacarose 0,3 , ........ 47

3.3.10. Solução de lisozima $(1,5 \mathrm{mg} / \mathrm{ml}) \ldots 4$

3.3.11. Solução de PEG 1000 (50\%) ........ 47

3.3.12. Solução de elementos traços ....... 48

3.3.13. Solução de dodecilsulfato de sódio ( $\operatorname{SDS}) 1,5 \% \ldots \ldots \ldots \ldots \ldots \ldots \ldots \ldots \ldots . \ldots 4$

3.3.14. Solução fenol-clorofórmio ........ 48

3.3.15. Solução de bicloreto de mercúrio $(15 \%) \quad \ldots \ldots \ldots \ldots \ldots \ldots \ldots \ldots \ldots \ldots \ldots \ldots \ldots$ 
Página

3.3.16. Soluções-estoque de antibióticos

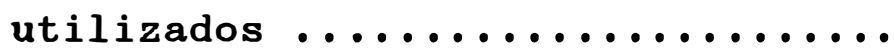

3.4. Tampões ............................. 49

3.4.1. Tampão P (protoplastos) .......... 49

3.4.2. Tampão borato (TEB) ............. 49

3.4.3. Tampão TE ..................... 50

3.4.4. Tampão da amostra para gel agarose • 50

3.4.5. Tampão do gel separador .......... 50

3.4.6. Tampão do gel empilhador ......... 50

3.4.7. Tampão eletrólito ou tris-glicerina pH $8,9 \ldots \ldots \ldots \ldots \ldots \ldots \ldots \ldots \ldots \ldots \ldots \ldots . \ldots \ldots \ldots$

3.4.8. Tampão da amostra para o gel poliacrilamida ....................

3.5. Manutenção ........................... 51

3.5.1. Suspensão de ésporos ............. 51

3.5.2. Manutenção dos microrganismos-teste 52

3.5.3. Suspensão microbiana para os ensaios ........................ 52

3.5.4. Leitura de cores ............... 53

3.6. Tratamento com agente intercalante ....... 53

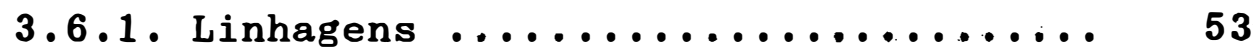

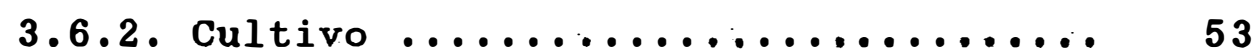

3.6.3. Determinação da concentração · de acriflavina ..................... 54

3.6.4. Ensaio antimicrobiano ........... 54 
Página

3.7. Extração de DNA plasmidial ............. 55

3.7.1. Linhagens utilizadas ............ 55

3.7.2. Cultivo ..................... 55

3.7.3. Obtenção de massa celular ........ 56

3.7.4. Extração (mini-preparação) ........ 56

3.7.5. Eletroforese em gel agarose (hori-

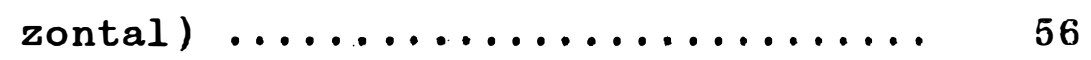

3.8._Caracterização de plasmídio conjugativo pela formação do fenótipo "pock" ......... 57

3.8.1. Linhagens utilizadas ............ 57

3.8.2. Cruzamento com S. Lividans TK24 ... 57

3.8.3. Expressão do fenótipo "pock" ....... 58

3.9. Formação, regeneração e fusão de protoplastos ........................... 59

3.9.1. Linhagens utilizadas ............ 59

3.9.2. Cultivo ..................... 59

3.9.3. Formação de protoplastos .......... 59

3.9.4. Regeneração de protoplastos ........ 60

3.9.5. Inativação de protoplastos ........ 60

3.9.6. Fusão de protoplastos ............ 61

3.9.7. Caracterização dos produtos de

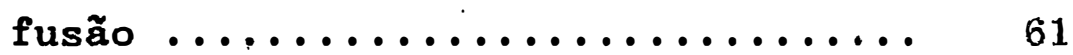

3.10. Estabilização dos setores .............. 62

3.11. Caracterização do fenótipo "pock" dos setores segregantes $\ldots \ldots \ldots \ldots \ldots \ldots \ldots$ 
Página

3.12.6.6. Plastificação do gel ... 72

3.13. Produção de antibiótico ................ 72

3.13.1. Linhagens $\ldots \ldots \ldots \ldots \ldots \ldots \ldots \ldots . \ldots 72$

3.13.2. Inóculo ................. 73

3.13.3. Fermentação ................ 73

3.13.4. Extração ................. 73

3.13.5. Ensaio antimicrobiano do líquido fermentado $\ldots \ldots \ldots \ldots \ldots \ldots \ldots$

3.13.6. Determinação quantitativa no líquido fermentado - Unidade Waksman

4. RESUltados E DiscUSSAO $\ldots \ldots \ldots \ldots \ldots \ldots \ldots \ldots \ldots$

4.1. Tratamento com agente intercalante ...... 75

4.1.1. Características fenotípicas das variantes obtidas após tratamento por acriflavina $\ldots \ldots \ldots \ldots \ldots \ldots \ldots$

4.2. Caracterização física de DNA plasmidial em Streptomvces felleus IA-M3079 ..........

4.3. Caracterização do fenótipo "pock" após cruzamento com s, lividans TK24 .......... 92

4.4. Fusão de protoplastos ............... 98

4.4.1. Formação e regenèração de protoplastos de linhagens para a fusão ..... 98 4.4.2. Processo de fusão de protoplastos .. 101 4.5. Estabilização dos setores ............. 104 
Página

3.12.6.6. Plastificação do gel ... 69

3.13. Produção de antibiótico ................ 70

3.13 .1 Linhagens ................... 70

3.13.2. Inóculo ..................... 70

3.13.3. Fermentação .................. 70

3.13.4. Extração .................... 70

3.13.5. Ensaio antimicrobiano do líquido fermentado ...................... 71

3.13.6. Determinação quantitativa no líquido fermentado - Unidade Waksman 71

4. RESULTADOS E DISCUSSAO ...................... 72

4.1. Tratamento com agente intercalante .......

4.1.1. Características fenotípicas das variantes obtidas após tratamento por

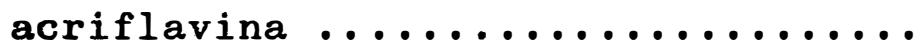

4.2. Caracterização física de DNA plasmidial em Streptomyces felleus IA-M3079 ...........

4.3. Caracterização do fenótipo "pock" após cruzamento com $s_{\text {s }}$ vidaras $T K 24 \ldots \ldots . . . \ldots$.

4.4. Fusão de protoplastos .................

4.4.1. Formação e regeneração de protoplastos de linhagens para a fusão ......

4.4.2. Processo de fusão de protoplastos .. 101

4.5. Eștabilização dos setores .............. 105 
Página

4.6. Caracterização dos setores segregantes .... 109 4.6.1. Análise dos segregantes quanto à formação do fenótipo "pock" ....... 109 4.6.2. Análise dos setores segregantes quanto às características fisiológicas e morfológicas ............ 112 4.6.3. Teste de resistência a antibióticos 122 4.6.4. Comportamento eletroforético ...... 124

4.7. Análise dos setores segregantes quanto à produção de antibióticos ............... ... 127 4.7.1. Caracterização do antifúngico ..... 134

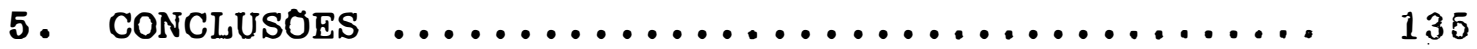

6. REFEREENCIAS BIBLIOGRAFICAS ............... 137 
PLASMIDIOS CONJUGATIVOS E FUSAO DE PROTOPLASTOS EM Streptomyces felleus

Autora: JANETE MAGALI DE ARAUJO Orientador: PROF. DR. JOAO LUCIO DE AZEVEDO

\section{RESUMO}

Diferentes espécies de Streptomyces, isoladas de amostras de solo do Estado de Pernambuco, mostraram-se produtoras de actinomicina, apresentando formação de pigmento solúvel amarelo-laranja, uma característica de linhagens produtoras desse antibiótico. Três dessas espécies foram ensaiadas em diferentes concentrações de acriflavina e revelaram elevada instabilidade na produção de actinomicina. Em Streptomvces felleus IA-M3079 os mutantes antibiótico-negativos obtidos através do tratamento com o agente intercalante mostraram inicialmente um único tipo morfológico, enquanto que os mutantes antibiótico-negativos de $\underline{S}$ regensis IA-M3053 apresentaram diferentes características fenotípicas. Foram, 


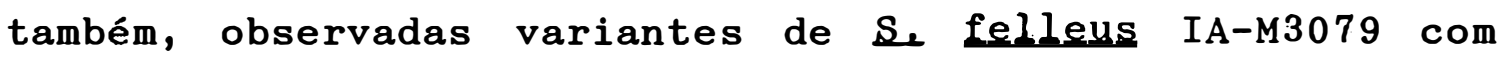
produção de pigmento amarelo-laranja mais intenso que o das

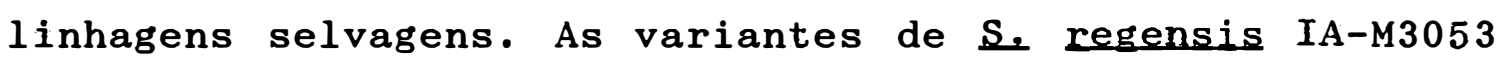
mostraram-se estáveis para esta característica $e$ as de $\underline{S}$. felleus IA-M3079 eram instáveis, vindo a desaparecer o pigmento após algumas transferências. Contudo, entre as variantes de $\underline{\mathrm{S}}$ felleus IA-M3079 destacou-se uma estável com inteñsa pigmentação. Foi observada, através do fenótipo "pock", nas três linhagens em estudo - $\underline{S}$ fellęus IA-M3079, S. parvulus IA-M3042 e S, regensis IA-M3053 - a presença de plasmídios conjugativos. A fusão de protoplasto entre $\mathbf{S}$. felleus IA-M3079 e a variante AF-3079(90/57) mostrou setores recombinantes com formação de pigmento azulvioláceo, que após estabilização e testes antimicrobianos apresentaram elevada atividade antifúngica. As culturas estabilizadas provenientes dos referidos setores segregantes, mostraram estreita similaridade com as parentais quanto às características bioquímicas, micromorfológicas e culturais e ao comportamento eletroforético. 0 antifúngico produzido pelos setores foi preliminarmente caracterizado através do espectro de absorção na luz ultravioleta. 


\section{CONJUGATIVE PLASMIDS AND PROTOPLAST FUSION IN \\ Streptomyces felleus}

Author: JANETE MAGALI DE ARAÚJO

Adviser: PROF. DR. JOAO LUUCIO DE AZEVEDO

\section{SUMMARY}

Different streptomyces species, isolated from soil samples of Pernambuco State, Brazil, produce actinomycin and present the formation of yellow-orange soluble pigment: a characteristic of strains producing that antibiotic. Three streptomyces species were tested in different concentrations of acriflavine and showed high instability in the actinomycin production. In Streptomyces felleus IA-M3079, the negative antibiotic mutants obtained through the treatment with the intercalant agent showed a single morphologic type, the negative antibiotic mutants of S. regensis IA-M3053 presented different phenotypical features. Besides, it were observed variants of $S_{\text {e fedlejes }}$ IA-M3079 with yellowish-orange pigment production more 
intensive than that of the wild strains. The $S$ regensis IA-M3053 variants showed themselves stable for this character and the $S$, felleus IA-M3079 variants were unstable, disappearing its pigment after some subcultivation. However, among the S. felleus IA-M3079 variants one appeared with intensive and stable pigment.

Through the pock phenotype it was observed the presence of conjugative plasmids in the three strains under study: S, felleus IA-M3079, S, parvulus IA-M3042 and S. regensis IA-M3053. The protoplast fusion between $\underline{S}$. felleus IA-M3079 and the variant AF-3079(90/57) produced recombinant sectors with formation of bluish violaceous pigment. Such sectors, after stabilization and antimicrobial tests present high antifungal activity. The purified and stabilized cultures obtained from the recombinant sector showed to be very similar to the parental cultures regarding to biochemical, micromorphological and cultural characteristics as well as to the electrophoretical patterns. The antifungal compound produced by the sector recombinant cultures was characterized through ultraviolet spectra (UV) and by antimicrobial spectra. 


\section{INTRODUÇAO}

Entre os actinomicetos são encontrados mais de 30 gêneros de bactérias Gram-positivas e, entre eles, encontra-se o gênero streptomyces que apresenta micélio aéreo eóm grande ramificação.

Streptomyces são bactérias filamentosas, aeróbicas que se assemelham às eubactérias com relação ao seu metabolismo e fisiologia e, aos fungos, com reląão à presença de micélio vegetativo e micélio aéreo com esporulação reprodutiva após crescimento em meio sólido.

A grande importância destas bactérias é a sua versatilidade na elaboração de inúmeros antibióticos, enzimas e vitaminas. Entretanto, é na produção de antibióticos que estes microrganismos se destacam. Aproximadamente, 6.000 antibióticos de origem microbiana já foram caracterizadós e cerca de $60 \%$ deles são produzidos por actinomicetos. Vale salientar que o gênero streptomyces é responsável por $90 \%$ destes compostos com grande aplicação prática na medicina humana ou veterinária, na agricultura e na indústria de alimentos.

As actinomicinas pertencem ao grupo dos antibióticos antitumorais com atividade relevante. Este 
grupo de antibióticos é constituído de cromopeptídeo vermelho com diferença na parte peptídica da molécula.

Em decorrência da importância destes metabólitos secundários, estudos básicos de microbiologia e genética têm sido conduzidos visando o melhoramento de linhagens produtoras. Por conseguinte, o conhecinento da localização, estrutura e função de genes que determinam a produção, a regulação e a resistência a antibióticos é indispensável para o desenvolvimento de eficientes programas de melhoramento.

Com vistas ao melhoramento de linhagens de Streptomyces produtoras de antibióticos, este trabalho teve como objetivos: 1) determinar a ocorrência de plasmídios em

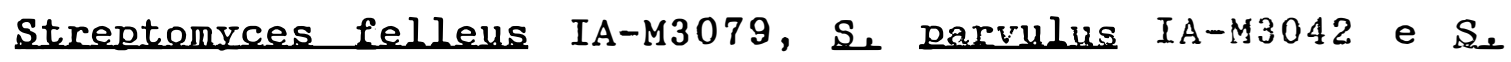
regensis IA-M3053, verificando a instabilidade da produção de actinomicina por tratamento com agente intercalante; 2) através de cruzamento com $S$, lividans TK24, caracterizar a presença de plasmídio conjugativo pela formação de zigose letal; 3) verificar, por fusão de. protoplastos entre a linhagem selvagem de $S_{\text {. felleus }}$ A-M3079 produtora de actinomicina e a variante $A F-3079(90 / 57)$ não produtora de actinomicina, a transferência do caráter produção de actinomicina pela formação do halo de inibição para Bacillus subtilis ; 4) realizar ensaios antimicrobianos dos 
setores segregantes obtidos por fusão de protoplastos, visando determinar o tipo de antibiótico produzido. 


\section{REVISAO DE LITERATURA}

\subsection{Actinomycetales: características gerais}

Actinomicetos é o nome genérico atribuído a um grupo de bactérias pertencentes à ordem Actinomycetales (BUCHANAN, 1917), cuja característica comum é a formação de hifas em algum estágio do seu desenvolvimento. Estes microrganismos começaram a ser estudados em 1872 com o isolamento de Streptotrix foersteri e Actinomyces boyis por F. Cohn e C.o. Harz, respectivamente, sendo atribuído a C.O. Harz a denominação de Actinomyces para designar as formas anaeróbicas, originalmente estudadas por ele. 0 termo Actinomyces surgiu na época de Pasteur e Koch e em grego significa. "fungos radiados" ("ray-fungi"), sugerindo que estes microrganismos eram cultivados e estudados como fungos. Segundo o Bergey's Manual 7ạ edição, na 'ordem Actinomycetales são encontrados diversos gêneros que apresentam características associadas a fungos, como pleomorfismo e formação de micélio aéreo. A formação de hifas em alguns gêneros é rudimentar, havendo rápida fragmentação. A ocorrência de uma densa população de actinomicetos no solo foi.. muito cedo evidenciada por WAKSMAN \& CURTIS (1916), sendo mais tarde adotado o nome 
genérico de streptomyces (WAKSMAN \& HENRICI, 1943) para designar o grupo predominante desses microrganismos cuja característica fundamental é a produção de micélio aéreo. Atualmente, a posição taxonômica destes microrganismos está bem definida dentro do reino Procarioto, baseada na proposta de Chattoni ${ }^{1}, 1937$ (citado $^{1}$ por MURRAY, 1974), que classifica os microrganismos quanto à sụa- organização celular, levando em consideração evidências bioquímicas, fisiológicas e microscópicas. Fundamentados nestes critérios é que vários estudos foram realizados com os actinomicetos, comprovando sua natureza procariótica.

As características essenciais de natureza procariótica dos actinomicetos são: ausência de membrana nuclear, ausência de organelạs citoplasmáticas e presença de ribossomos do tipo 70 .

\subsubsection{Posição taxonômica de streptomycess}

Os Streptomyces são bactérias filamentosas, Gram-positivas, encontradas principalmente no :solo em condições de aerobiose estrita.

Do ponto de vista biotecnológico, os estreptomicetos são morfológica e quimicamente mais

1 CHATTON, E. (1937) Titres et Travaux Scientifiques, Sète, Soltano 
versáteis do que a bactéria Escherichia celi. O crescimento de Streptomvces em meio sólido sofré um ciclo de desenvolvimento que inclui uma fase de micélio vegetativo, seguida de formação de micélio aéreo e esporulação reprodutiva.

Além desta complexidade morfológica, os Streptomyces são diferentes da E coli ou de Bacillus subtilis pela riqueza do conteúdo de seu DNA em guanina e citosina $(G+C)$, além de possuirem genoma 3 vezes maior que os dessas bactérias (BENIGNI et alii, 1975).

A diferenciação morfológica nestes microrganismos é de interesse relevante por causa da ligação regulatória existente entre esporulação e produção de antibióticos (HOPWOOD, 1981b).

o gênero Streptomvces era incluído na família Streptomycetaceae e podia ser distinguido de uma variedade de outros gêneros de actinomicetos por meio de propriedades quimiotaxonômicas e micromorfológicas.

o ĉritério químico utilizado para a classificação de actinomicetos aeróbicos está fundamentado nos estudos realizados por BECKER et alii (1964) e por YAMAGUCHI (1965), os quais caracterizam quatro tipos de parede celular para os actinomycetos. Estes tipos de parede são diferentes em seus conteúdos de açúcares e aminoácidos. Nos streptomyces a parede celular é do tipo I, com a 
ocorrência de ácido-2-6-diaminopimélico (DAP) em suas formas LL e DL, além de conter alanina, ácido ğlutâmico e glicina. Entre as bactérias Gram-positivas, os estreptomicetos são as únicas que apresentam micélio aéreo bem desenvolvido em decorrência do alto conteúdo de DAP (LECHEVALIER \& LECHEVALIER, 1970).

Em recente revisão, DIETZ (1986) enfatiza que a composição química do hidrolisado celular total constitui um excelente critério taxonômico para diferenciar Nocardia de Streptomyces.

Micromorfologicamente, este gênero mostra cadeias de esporos (esporóforos) que se apresentam longas ou curtas, em espirais ou retas. Baseadas nesta micromorfologia, várias chaves de classificação foram sugeridas (KUSTER, 1972).

Em decorrência de Streptomyces produzir uma grande variedade de antibióticos de interesse comercial, durante muito tempo a descrição de espécies era arbitrária e nem todas as culturas descritas na literatura eram encontradas nas chaves de classificação de Streptomvces. Por causa da "criação" de - várias espécies, foram padronizados métodos para caracterizar as espécies de Streptomvces e, entre 1966 e 1974, o "International Streptomyces Project" (ISP) redescreveu cerca de 450 
espécies, homogeneizando os critérios para a determinação das mesmas (SHIRLING \& GOTTLIEB, 1968a,b, 1969, 1972).

Os critérios adotados pelo ISP para os Streptomyces levam em consideração características de micélio aéreo, reverso e pigmento, quando crescidos sobre vários meios contendo ágar, a mícromorfologia da cadeia de esporos e a superfície dos mesmos revelada ao microscópio eletrôníco. Estas características, adicionadas da capacidade de crescimento em meio sintético com fontes de carbono diversas e a metabolização de certos substratos, foram a base para a distinção entre espécies neste gênero, proposta por SHIRLING \& GOTTLIEB (.1966).

Segundo DIETZ (1986), os métodos adotados pelo ISP, associados a critérios quimiotaxonômicos e a diferentes chaves de classificação morfológica (NONOMURA, 1974; IUSTER, 1972; SZABO et alii, 1975) e chave de classificação numérica (WILLIAMS et. alii, 1983; KURYLOWICZ et alii, 1976), possibilitam a descriçäo de uma espécie. Atualmente, métodos moleculares envolvendo sequenciamento e reassociação de macromoléculas, especialmente ácidos nucleicos,. estão revolucionando a classificação de Procariótos, incluindo os Streptomyces (SCHLEIFER \& STACKEBRANDT, 1983).

A última edição do Bergey's Manual (1989) divide os actinomicetos em dez grupos através da 
classificação supragenérica. Esta classificação foi baseada na distância fenética entre diferentes linhagens de bactérias filamentosas, calculada através da análise comparativa dos oligonucleotídeos da fração ribossomal 16S resistentes a ribonucleases (SCHLEIFER \& STACKEBRANDT, 1983). Esta macromolécula foi utilizada por apresentar sequência altamente conservada e elevada estabilidade genétićá (STACKEBRANDT \& WOESE, 1981).

Dentro destes grupos supragenéricos encontram-se os estreptomicetos com cinco "gêneros diferentes que têm entre si tipos de parede e peptidoglicano semelhantes, porém diferem nos seus contéudos de ácidos graxos, menaquinonas e fosfolipideos.

No Bergey's Manual (1989) são descritas 142 espécies de streptomyces, 68 resultantes de un estudo de taxonomia numérica feito por WILLIAMS et alii (1983) e 74 baseadas no "International Streptomyces Project" (ISP) (SHIRLING \& GOTTLIEB, 1968a,b, 1969, 1972).

Os dados resultantes da taxonomia numérica e da taxonomia molecular vieram fortalecer a taxonomia convencional utilizada desde WAKSMAN (1961) e reforçada pela quimiotaxonomia, como foi enfatizado por DIETZ (1986). 


\subsection{Genética de Streptomrces}

A engenharia genética de microrganismos indústriais alcança hoje um grande desenvolvimento, graças às técnicas de genética desenvolvidas nos microrganismos utilizados nos trabalhos de interesse acadêmico, como E. coli e Bacillus subtilis, que são importantes hospedeiros nas pesquisas que utilizam a técnica com o DNA recombinante.

As linhagens s. coelicolor A3 (2) e s. lividans, pertencem ao seleto grupo de microrganismos com uma genética experimental bem definida, sendo bastante utilizados nos trabalhos para estudos moleculares e de clonagens .

Até 1955; os estudos genéticos com Streptomyces eram relacionados com as observações sobre mutagênese. Somente, após a descoberta da recombinação genética em Streptomyces coelicolor A3(2) por SERMONTI \& SPADA-SERMONTI (195.5) e HOPWOOD (1957), intensificaram-se as pesquisas na área da genética desses microrganismos. Entretanto, os avanços só foram atingidos quando HOPWOOD (1959); HOPWOOD \& SERMONTI (1962) déterminaram o grupo de ligação genética de $S$. coelicolor A3(2) e, posteriormente, a análise genética mostrou que este grupo de ligação era circular (HOPWOOD, 1967). 


\subsubsection{Estrutura genômica}

Observações feitas ao microscópio eletrônico

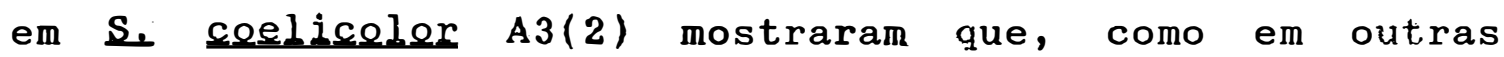
bactérias, o DNA está presente na célula em forma condensada, frequentemente em múltiplas cópias por célula hifal, porém somente em única cópia nos esporos haplóides (HOPWOOD_ \& GLAUERT, 1960). Segundo WESTPHELING (1980), a molécula circular de DNA em $S$, coelicolor está organizada em estrutura superhelicoidal associada com proteínas e outras moléculas necessárias para estabilização da estrutura, igualmente, como foi observado em nucleóides isolados de Escherichia coli e Bacillus subtilis por WORCEL \& BURGI (1974) e GUILLEN et alii (1978).

A quantidade de DNA em microrganismos, geralmente, é determinada através da cinética de reassociação e, segundo BENIGNI et alii (1975); o conteúdo de DNA no genoma de E e celi está em torno de $(2,28 \pm 0,19) \times 10^{9}$ daltons, enquanto que, no genoma de $\underline{s}$ coelicolor este valor é cerca de três vezes maior, isto é: $(7,23 \pm 0,51) \mathrm{x}$ $10^{9}$ daltons.

Experimentos realizados por vários pesquisadores, mostram que o tamanho do genoma em Streptamyces variou de $3,69 \times 10^{9}$ a $7,3 \times 10^{9}$ daltons (Tabela 1 ).

Estes experimentos eram diferentes quanto ao método utilizado e quanto ao cálculo do conteúdo de DNA. 
Entretanto, vale salientar que esta heterogeneidade no conteúdo de DNA no esporo e no micélio pode decorrer da ausência de segregação nos nucleóides irmãos após repetidas duplicações da região hifal ou, possívelmente, ausência ou presença de DNA extracromossomal (KRETSHCMER \& KUMMER, 1987). A análise dos resultados constantes da Tabela 1, realizada por HUNTER \& ECKHARDT (1988), mostra que o DNA genômico em Streptemyces variou de $3,69 \times 10^{9}$ a $7,3 \times 10^{9}$ daltons, significando um aumento de 1,5 a 2 vezes em relação a E. coli e não três vezes, como foi sugerido por BENIGNI ( 1975$)$.

Tabela 1

Determinação do DNA genômico em Streotemycess (HUTTER \& ECKHARDT, 1988)

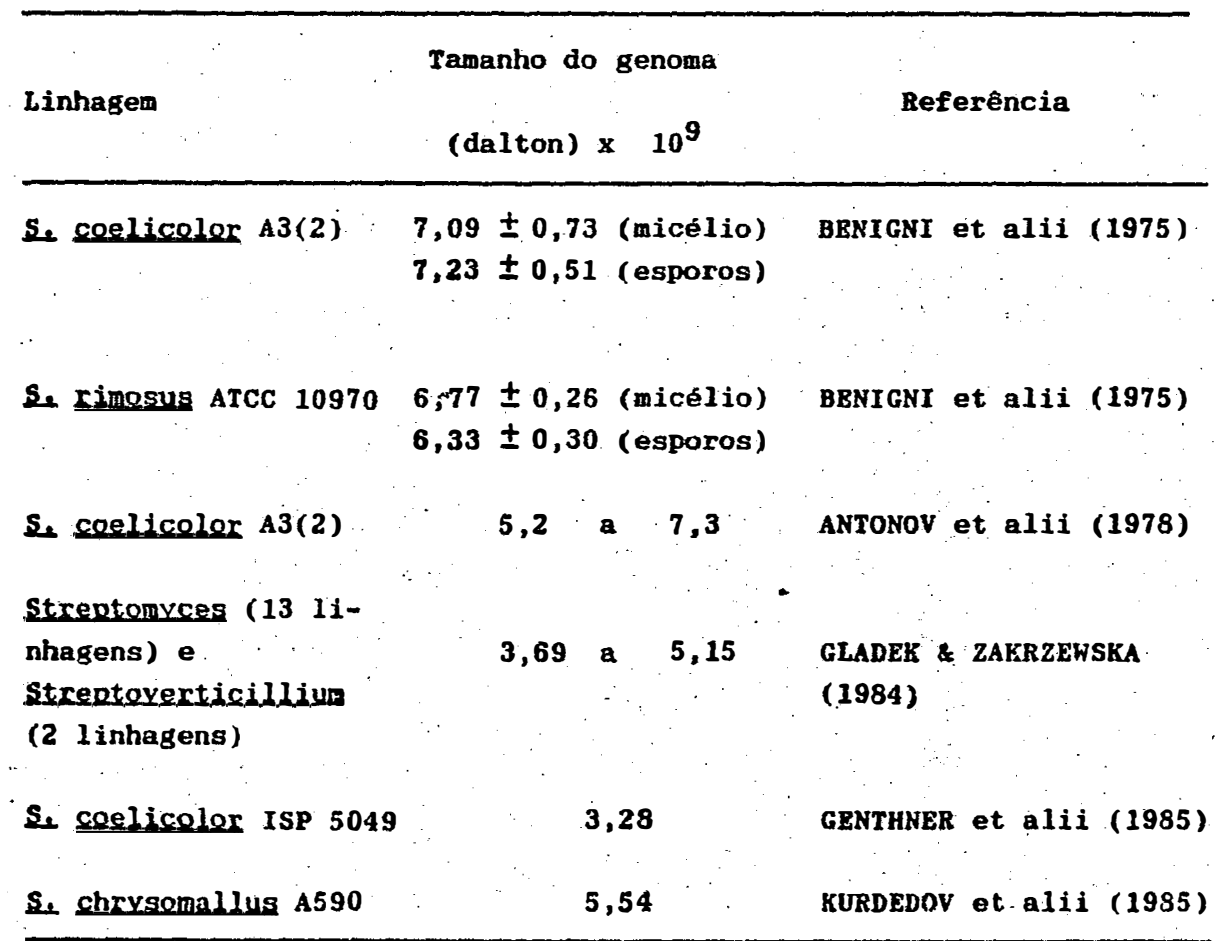


2.2.2. Complexidade genômica

A distribuição irregular dos diferentes tipos de nucleotídeos ao longo do DNA cromossomal em Streptomyces constitui uma característica marcante nestes microrganismos. Esta irregularidade pode influenciar a cinética de reassociação, sendo um fator que dificulta a determinação do tamanho do genoma em Streptomyces.

o conteúdo de guanina mais citosina $(G+C)$ em Streptomyces varia de 70 a $74 \%$, (TEWFICH \& BRADLEY, 1957; BENIGNI et alii, 1975) enquanto que, em E. celi este percentual é de $51 \%$, como observado através de vários trabalhos (FRONTALLI et alii, 1965; USDIN et alii, 1984). Em actinofagos, bem como em plasmídios, a porcentagem de G+C se apresenta similar ao observado em DNA cromossomal (BIBB et alii, 1977; BIBB et alii, 1981; PERNODET \& GUEERINEAU, 1981).

Este alto conteúdo de $G+C$ pode ter um significado evolucionário e, consequentemente, envolver o processo de mutação espontânea e induzida (BALTZ, 1986). Segundo SINGER \& AMES (1970), esta distribuição irregular de guanina e citosina pode réduzir a probabilidade de mutação pelos raios ultravioleta (UV) em decorrência da baixa frequência de timina adjacente. Outra consequência do alto percentual de $G+C$ é a seleção para enzimas de restrição que cortam o DNA em sítios de reconhecimento com 
baixo teor destas bases nitrogenadas, como as enzimas EcoR1, Hind III, Hpa I, Kpn I que cortam o DNA em grandes fragmentos, enquanto que BamH1, PstI e SalI, cortam predominantemente em sitios ricos em $G+C$ dando assim pequenos fragmentos (CHARTER \& HOPWOOD, 1983).

Um aspecto interéssante em streptomyces é o comportamento do DNA total digerido por enzimas de restri-ção. Geralmente, eletroforese em giel agarose do DNA total bacteriano digerido com enzimas de restrį̣ão, mostra arrastes longos da formação de fragmentos únicos de DNA presente em única cópia no cromossomo. Entretanto, a digestão com enzimas de restrição de DNA em streptonvsess freqüentemente revela intensas bandas superpostas, indicando a presença de múltiplas seqüencias repetidas (SCHREMPF, 1982a; 1982b; ONO et alii, 1982; ROBINSON et alii, 1981). Foi devido a este comportamento eletroforético

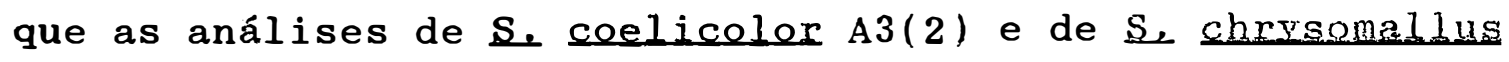
revelaram que cerca de $5 \%$ do genoma destas bactérias filamentosas consístem de seqüências de DNA repetido (ANTONOV et alii, 1977). O estudo realizado por USDIN et alii (1984) com 14 diferentes.linhagens de Streptemyses. mostrou que entre elas cerca de 4 a $11 \%$ do genoma apresenta seqüências repetidas e que estas seqüências caem dentro de uma classe distinta com baixo percentual de $G+C$. Entre as linhagens examinadas por USDIN, apenas Se rimosus NRRL. 
24455 não apresentou seqüências repetidas. A complexidade genômica em streptomyces pode resultar em "linhagens carregando extensas deleções ou amplificações de DNA.

\subsubsection{Ocorrência de plasmídios}

Em geral, estreptomicetos possuem elementos extracromossômicos de tamanhos variados, desde $4 \mathrm{~kb}$ até mais de $200 \mathrm{~kb}$ e o número de cópias por cromossomo varia desde uma unidade até centenas. Os plasmídios têm atraído a atenção de muitos pesquisadores em decorrência de sua larga distribuição, podendo estar envolvidos na fertilidade, na produção e resistência de antibiótico; na diferenciação e também no rearranjo do genoma. Com o rápido desenvolvimento da engenharia genética, os plasmídios têm se tornado um instrumento indispensável na clonagem e transferência de genes.

Várias investigações revelam que elevada proporção, aproximadamente $23 \%$; das linhagens de estreptomicetos, abrigam plasmídios como revelado pela análise dos diferentes trabalhos. OKANISHI et alii (1980) mostram que das 32 linhagens analisadas, 7 (22\%) possuem plasmídios; e mais, segundo HOPWOOD et alii (1981), 11 das 44 linhagens (25\%) abrigam plasmídios; OMURA et alii (1981), verificaram que entre 21 linhagens analisadas, 5 (24\%) tinham plasmídios; TOYAMA et alii (1982), verificaram 
que 16 de 69 linhagens (23\%) continham plasmídios, e DANIEL \& TIRABY (1983) de 120 linhagens analisadas constataram que 21 (17.5\%) abrigavam plasmídios. Estes relatos mostram a proporção média de linhagens de Streptomyces que naturalmente possuem plasmídios.

Em geral, os plasmídios são detectados na forma de DNA circular covalentemente fechado (CCC), porém ocasionálmente elementos lineares como pSLA 2 de $\underline{S}$ rochej (HIROCHIKA et alii, 1984) com $17 \mathrm{~kb}$ e o SCP 1 com $340 \mathrm{~kb}$ (KINASHI \& SHIMAJI, 1987) podem ser detectados, através da técnica de eletroforese ortogonal (OFAGE).

A linhagem selvagem de $\mathbf{S}$. coelicolor A3(2) possui pelo menos dois plasmídios sexuais, SCP1 (VIVIAN, 1971) e SCP2 (BIBB et alii, 1977). Estes plasmídios se encontram em estado autônomo (SCP1 + SCP2 + ), sendo que cada plasmídio é perdido espontaneamente em cerca de $0,03 \%$ a $1,0 \%$ dos esporos originados de uma cultura contendo plasmídio (VIVIAN \& HOPWOOD, 1970; BIBB et alii, 1977; BIBB \& HOPWOOD, 1981) ôu em alta frequência ( 2 a 25\%) após obtenção e regeneração de protoplastos (HOPWOOD, 1981a,b).

Outros plasmídios como SLP1.1 a SLP1.6 foram identificådos após cruzamento pela transferência de DNA da linhagem de S. coelicolor A3(2) SCP1 - SCP2 - para S. lividans 66. Essa família de plasmídios autônomos SLP1.1 a SLP1.6 foi revelada em $S$ lividans 66 e se origina de uma 
seqüência cromossômica de s. coelicolor (BIBB et alii, 1981a). Igualmente os plasmídios autônomos piJ110 e piJ408 provavelmente se originam dos cromossomos de $\underline{\text { s. parvulus } e}$ S. glaucescens respectivamente após cruzamento dessas linhagens com s, lividans 66 (HOPWOOD et alii, 1984a).

Esses plasmídios'e talvez outras sequiências de DNA, ocorrem naturalmente em forma integrada no cromóśsomo, ocasionalmente formam alças ("loop out"), duplicam-se autonomamente e são detectados em hospedeiros como s. Lividans 66 .

\subsubsection{Transferência de plasmídioss}

Muitos dos plasmídios isolados ou detectados em estreptomicetos são "cripticos", isto é, não estão ainda associados a um fenótipo. Entretanto, na maioria das vezes, os plasmídios podem estar associados a fertilidade, assegurando sua própria transferência e a mobilização de marcas cromossomajis no cruzamento.

Os plasmídios de $S$, coelicolor $A 3(2)$ e de outros estreptomicetos são conjugativos e pela análise da região de transferência (trä) desses plasmídios, estas regiões podem ser geneticamente mais simples do que a região tra em Ee celi . Os experimentos iniciais mostrando que plasmidios pequenos como SLP1.6 de $9,4 \mathrm{~Kb}$ (BTBB et alii, 1981a) e o plasmídio piJ10I de 8,9 fib (KIESER et 
alii, 1982) são autotransmissíveis, comprovam que o mecanismo de transferência em estreptomicetós é mais simples que em outras bactérias. Estudos genéticos e moleculares realizados por KIESER et alii (1982) com o plasmídio piJ101 mostram que um segmento de $2,1 \mathrm{~Kb}$ compreende a região de transferência desse pläsmídio,

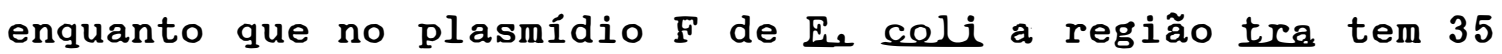
Kb (WTLLETS \& SKURRAY, 1980). Os plasmídios pequenos mostram grande vantagem para serem utilizados como vetores de clonagem.

Além destes plasmídios, outros, isolados de Streptonyces são autotransmissíveis e incluem pSF689 e pSF765 com 13,7 e $7,2 \mathrm{~kb}$, respectivamente (MURAKAMI et alii, 1983); piJ110 e piJ408 têm 13,6 kb e $15 \mathrm{~kb}$, respectivamente (HOPWOOD et alii, 1984a); e pTA 4001 (5,9 kb) (KOBAYASHI et alii, 1984). Todos estes plasmídios são transferíveis quando ensaiados em S. lividans 66 SLP2 SLP3 - e também em outras linhagens como s, coelicelor A3(2) e se chartreusis Em decorrência da elevada frequência de plasmídios conjugativos entre os estreptomicetos, foi sugerido por HOPWOOD et alii (1986) que algumas funções do hospedeiro necessárias para a transferência de plasmídios encontram-se espalhadas entre estas bactérias filamentosas. 


\section{$2 \cdot 2 \cdot 3 \cdot 2$. Zigose letal}

Observações iniciais realizadas por BIBB et alii (1977) mostraram que o desenvolvimento confluente de uma linhagem de $\underline{S}$ coelicoler A3(2) SCP2 - era retardado, principalmente o micélio aéreo, por um ou dois milímetros a partir do ponto de contacto com uma colonia contendo o plasmídio SCP2* (variante do plasmídio SCP2 com elevada frequência de transferência). Este fenômeno foi chamado de "zigose letal" por analogia com o plasmídio F de E. coli K12 em que as células F - podem ser mortas por conjugação simultânea com linhagens Hfr. (SKURRAY \& REEVES, 1973). Segundo BIBB et alii (1977), um inibidor difusível poderia ser a causa desta zona de inibição. Visando esclarecer este fato, BIBB et alii (1978) obtiveram esporos únicos de uma linhagem SCP2* e espalharam dentro de uma cultura confluente da SCP2 - tendo observado pequenas colonias com zonas circulares de inibição, as quais foram chamadas de "colônias pock"..

Os plasmídios de streptomyces que mostram este efeito, atualmente são descritos como fenótipo zigose letal (Ltz). Este fenótipo não é confinado apenas a SCP1 e SCP2*, mas a inúmeros plasmídios que se mostram conjugativos.

A mudança fisiológica responsável pe]a reação "pock" visível ainda não é entendida, porém, segundo 
HOPWOOD et alii (1986), uma hipótese favorável seria que possivelmente ocorre uma desrepressão temporária de algumas funções de transferência dentro do micélio livre de plasmídio.

O uso deste fenótipo Ltz é muito útil para a Genética de streptomices apresentando-se como um instrumento importante no sistema de transformação por DNA plasmidiál em protoplastos de streptemvees

\subsection{Produção de antibióticos}

A distinção entre antibióticos "sensu strictu" e bacteriocínas de E. celi ou toxinas "killer" de levedura, baseia-se sobretudo na formação dos antibióticos que é mais de natureza genética (HOPWOOD, 1978). Enquanto a síntese das tetraciclinas ou de um antibiótico macrólido é codificada por vários genes, as colicinas e as toxinas "killer" são proteínas que se originam da informação de um único gene estrutural.

Os antibióticos são produzidos por diferentes grupos de microrganismos cujo processo regulatório ainda não é completamente entendido. Estes metabólitos secundários surgem a partir da modificação dos intermediários do metabolismo primário que reunem metabólitos primários e formam estrutaras complexas pela 
ação de enzimas específicas, as quais são expressadas sob determinadas condições de crescimento.

A transformação da população de crescimento celular (tropofase) em população produtora de antibiótico (idiofase) é um tipo de diferenciação celular análogo à diferenciação morfológica do micélio a esporos que. ocorre em meio sólido (SENO \& HUTCHINSON, 1986).

o estudo genético do processo biossintético constitui um sistema muito bom para a investigação do mecanismo regulatório envolvido na diferenciação celular destas bactérias filamentosas.

2.3.1. Importância de Streptomyces na produção de antibióticos - Actinomicina

Uma das propriedades mais importantes em Streptomvces é sua capacidade em elaborar uma variedade de estruturas químicas com grande valor social e econômico.

Estas bactérias comumente isoladas do solo, têm atraído a atenção de muitos microbiologistas, porque cerca de 50\% das linhagens isoladas apresentam ação antimicrobiana.

Na década de 1940 o microbiologista Selman Waksman, realizando isolamento de bactérias a partir de solo, descobriu o primeiro antibiótico - actinomicina produzido por um estreptomicețo que foi denominado 
Streptomyces antibioticus por causa da sua potente atividade antibacteriana. Entretanto, em decorrência de sua elevada toxicidade, a substância não mereceu atenção na época. Posteriormente, foi isolado s, griseus, produtor da estreptomicina, o qual causou um grande impacto porque não era tóxico e apresentava ação antimicrobiana para Mycobacterium tuberculosis, sendo utilizado com eficácia na cura da tuberculose (WAKSMAN \& WOODRUFF, 1941).

Em decorrência desse sucesso, as pesquisas se intensificaram na busca do isolamento de amostras de Streptomrces que produzissem outras substâncias ativas. A versatilidade desse gênero foi surpreendente e diversas linhagens foram isoladas visando à produção de antibióticos com diferentes estruturas químicas.

Em recente revisão, QUEENER \& DAY (1986) enfatizam que aproximadamente 6000 antibióticos de origem microbiana foram caracterizados e cerca de $60 \%$ destes são produzidos por actinomicetos, enquanto que os restantes são metabólitos de fangos e ou eubactérias. Entre os antibióticos isolados de actinomicetos, $90 \%$ são originários de Streptomyces e encontram aplicação na medicina veterinária e humana, na agricultura e na indústria de alimentos.

As actinomicinas compreendem um grupo de cromopeptídeos vermelhos que diferem na parte peptídica da 
molécula. A condensação de duas moléculas do ácido 4metil-3 hidroxiantranílico origina actinocin que é o cromóforo da actinomicina (WAKSMAN, 1968). O papel terapêtico das actinomicinas foi descoberto a partir dos trabalhos de HACKMANN (1968) no tratamento da linfogranulomatose maligna (doença de Hodgkin).

As actinomicinas são produzidas por várias espécies- de streptomyces, como $S$ antibioticus, $S$. parvulus, $S$. chrysomallus, S. melanochromogenes, $S$. felleus, S, regensis, S. spadicis, entre outras. Diferentes tipos de actinomicinas são produzidos durante a fermentação, dependendo da linhagem utilizada e da composição do meio.

2.3.2. Genética da produção de antibióticos

o conhecimento da genética de Streptomyces é de fundamental importância, considerando-se principalmente a produção de metabólitos secundários cuja investigação poderá influenciar a produção de antibióticos e a obtenção de novas estruturas biossintéticas.

As observações 'realizadas por vários pesquisadores buscam conhecer a localização e a organização dos genes estruturais na biossíntese de antibiótico das várias linhagens produtoras (HOPWOOD, 1978; OKANISHI, 1979, 1980; SCHREMPF, 1982; HOPWOOD et alji, 1983). o 
envolvimento de plasmídios em muitas linhasens produtoras de antibióticos foi sugerido em decorrência de várias observações: a) a formação de antibióticos em algumas linhagens era instável; b) a freqüência de mutantes antibiótico-negativas aumentava após tratamento com corantes intercalantes; c) transferência por infeç̧ào do caráter produção de antibiótico.

Entretanto, HÜTER \& ECKHARDT (198\%), fazendo uma análise detalhada dos trabalhos realizados nos últimos anos mostram que genes estruturais biossintéticos estão localizados principalmente em cromossomos, como pode ser resumido na Tabela 2 . 
Tabela 2

Localizaçăo cronossomal e extracrosossonal de genes estrutarais para a biossíntese de antibióticos (Gürr?R \& BCREARDP, 1988)

\begin{tabular}{|c|c|c|c|}
\hline $\begin{array}{l}\text { Controle } \\
\text { genético }\end{array}$ & Antibiótico & $\begin{array}{l}\text { Linhage } \\
\text { produtora }\end{array}$ & Referências \\
\hline Cronossono & actinorrodina & Le coelicolos $43(2)$ & $\begin{array}{l}\text { QRIGEP \& ROPROOD } \\
\text { (1976b); RODD \& } \\
\text { BOPHOOD (1979); et alii(1986b) }\end{array}$ \\
\hline Cronossoro & $\begin{array}{l}\text { etildinetiletil-arô- } \\
\text { aio-broneto (CDA) }\end{array}$ & $\mathcal{E}$ ceelicelor $\mathrm{i3}(2)$ & HOPROOD \& RBIGH (1983) \\
\hline Cro1088010 & cloranfenicol & S. reneznelat & $\begin{array}{l}\text { ARAGAPA et alii (1979); } \\
\text { ABUBD \& PINING (1983) }\end{array}$ \\
\hline & eritroniciaa & Sacchaco olyspere & NBBBB et alii (1985) \\
\hline Crovossono & holoricina & \& clandigergs & IIRBY (1978) \\
\hline Cronossono & $\begin{array}{l}\text { hidroxiestrep- } \\
\text { toricina }\end{array}$ & S. glancescens. & $\begin{array}{l}\text { CRARERI et alii (1983); } \\
\text { OIHPBR-KHAR et alii (1984) }\end{array}$ \\
\hline Cronos8010 & $\begin{array}{l}\text { oxitetracicli- } \\
\text { ad }\end{array}$ & $\begin{array}{l}\frac{S_{1}}{\text { cirosns }} \\
\text { (linhager soviética) } \\
\text { Se rirosas }\end{array}$ & $\begin{array}{l}\text { BORORIX \& MIPDLIR (1971); } \\
\text { PIJAR \& ALACBPIC (1979) } \\
\text { RHODRS et alii }(1981,1984)\end{array}$ \\
\hline Grovossono & $\begin{array}{l}\text { rifaricine } \\
.\end{array}$ & $\begin{array}{l}\text { Arrcolatonsis (H.) } \\
\text { eeditectanei }\end{array}$ & $\begin{array}{l}\text { SCEOPP \& BIIBSCB (1979); } \\
\text { GHISALBA et alii (1984) }\end{array}$ \\
\hline Grolossono & $\begin{array}{l}\text { "pignento rer- } \\
\text { velho" }\end{array}$ & Se coelicolor A3(2) & BUDD \& BOPHOOD (1980) \\
\hline Crorossoro & zorbaricina & $\begin{array}{l}\text { S. bikiniensis } \\
\text { pace zodbensis }\end{array}$ & COATS \& ROBSBR (1991) \\
\hline Plasuidio & retilenoricina & $\begin{array}{l}\text { Se coelicolor } \\
\text { Se riolacens-ruber } \\
\text { SAHT } 95570\end{array}$ & $\begin{array}{l}\text { RBIGH \& EOPHOOD (1976a) } \\
\text { RIRBY \& BOPROOD (1976a); } \\
\text { AGUILAR \& HOPHOOD (1982); } \\
\text { dIMASHI \& SHIKAJI (1987) }\end{array}$ \\
\hline $\begin{array}{l}\text { Plasnidio } \\
\text { (discrtírel) }\end{array}$ & $\begin{array}{c}\text { tilosina } \\
\vdots \\
\end{array}$ & S Iradie & $\begin{array}{l}\text { BALIL et alii }(1981,1982) ; \\
\text { BALTL (1982); SBRO \& } \\
\text { GOACHIXSOR (1986); } \\
\text { STONBSIPBR et alii (1986) }\end{array}$ \\
\hline $\begin{array}{l}\text { Plasuídio } \\
\text { (análise } \\
\text { inconpleta) }\end{array}$ & $\begin{array}{l}\text { aureoricina } e \\
\text { estreptoricina } A \text { e } B\end{array}$ & Se ceelicelor $A 3(2)$ & PRODST et alii (1979) \\
\hline $\begin{array}{l}\text { Plasnídio } \\
\text { (indicativo) }\end{array}$ & $\begin{array}{l}\text { aureotricina e } \\
\text { kasuganicias. }\end{array}$ & s. tasngaensis & $\begin{array}{l}\text { ORARISHI et alii(1979); ORARISHI } \\
\text { \& URBLARA (1979); BURGMI et } \\
\text { alii 1982) }\end{array}$ \\
\hline $\begin{array}{l}\text { Plasuídio } \\
\text { (indicativo) }\end{array}$ & cefanicina & Si grisens & PARAG (1999) \\
\hline $\begin{array}{l}\text { Plasuídio } \\
\text { (indicativo) }\end{array}$ & gingfenguicina & Se singfengnreticns & ZHBBG et alii (1982) \\
\hline $\begin{array}{l}\text { Plasuídio } \\
\text { (indicativo) }\end{array}$ & espiranicina & S. atlolaciens. & IRRDL et alii (1982) \\
\hline $\begin{array}{l}\text { Plasuídio } \\
\text { (indicativo) }\end{array}$ & estreptonicina & S. Eciseng & $\begin{array}{l}\text { GQOARe et alii (1980); aUB et } \\
\text { alii }(1981,1985)\end{array}$ \\
\hline
\end{tabular}

- De acordo cos BaLTl (1980) o gea fyl a pode estar localizado crozossomalnente. 
2.3.2.1. Papel dos plasmídios na produção de antibióticos

A única evidência genética da ocorrência de genes estruturais em plasmídio foi demonstrada na produção de metilenomicina A. O plasmídio $\mathrm{SCP}_{1}$ foi demonstrado geneticamente em S. coelicolor A3(2) pelas suas propriedades de recombinação (VIVIAN, 1971). A linhagem $\mathrm{SCP}_{1}+$ produzia uma substância difusível que inibia a linhagem $\mathrm{SCP}_{1}{ }^{-}$; posteriormente esta substância foi caracterizada como metilenomicina A por WRIGHT \& HOPWOOD, 1976a,b). Em relação ao plasmídio conjugativo as linhagens apresentam-se em. três formas: $\operatorname{SCP}_{1}^{+}$(autônomo); $\mathrm{SCP}_{1}$ ' (integrado), ou $\mathrm{SCP}_{1}$ - (ausente), (HOPWOOD et alii, 1973). Fundamentados nestes estudos, KIRBY \& HOPWOOD (1977) concluíram que $\mathrm{SCP}_{1}{ }^{-}$não produz metilenomicina e é sensível à adição exógena desse antibióticio. Igualmente, pelas propriedades conjugativas dessas linhagens, eles observaram que, cruzamentos com S. lividans 66 e S, parvulus ATCC 12434 não produtoras e sensíveis a metilenomicina A, mostravam transconjugantes resistentes e produtores desse antibiótico.

Investigação similar foi realizada por AGUILAR \& HOPWOOD (1982) com a linhagem se violaceoruber SANK 95570, também produtora de metilenomicina. Através da microscopia eletrônica, aqueles pesquisadores detectaram 
nesta linhagem um plasmídio pSV1 de 110 Mdal que hibridizava com uma sonda contendo o gene para codificar metilenomicina A.

O plasmídio $\mathrm{SCP}_{1}$ de S. coelicolor, embora tenha sido o primeiro plasmídio detectado geneticamente, foi durante muito tempo refratário ao isolamento físico, mesmo pelo uso de diferentes métodos. Entretanto, em comunicáção recente, KINASHI \& SHIMAJI (1987) e KINASHI et alii (1987), utilizando a técnica OFAGE, conseguiram isolar um grande plasmídio linear com cerca de $340 \mathrm{~kb}$, o qual contém genes de resistência e de biossintese a metilenomicina $\mathrm{A}$.

Embora não existam ainda trabalhos conclusivos, várias linhagens de estreptomicetos produtoras de antibióticos sugerem a ocorrência de plasmídios na produção de alguns metabólitos secundários.

- plasmídio $\mathrm{SQP}_{1}$ de $\mathrm{S}_{\text {. gingfengmyceticus }}$ pode conter genes estruturais para a biossintese de gingfengmicina (ZHENG et alii, 1982), enquanto que o plasmídio pSG1 pode ser o responsável pela sintese de estreptomicina em uma linhagem:de s. griseus (ZHUANG et alii, 1980; XUÉ et alii, 1981), entretanto a análise ainda é incompleta.

Igualmente incompleta é a demonstração da ocorrência de plasmídios em $S$. antibiaticuss e se Dacvulus, 
ambos produtores de actinomicina, postulada por OCHI \& KATZ (1978; 1980), após a fusão de protoplastos entre linhagens auxotróficas. Eles observaram que a fusão entre linhagens auxotróficas produtoras $\left(\operatorname{act}^{+}\right)$e não produtoras (act $\left.{ }^{-}\right)$de actinomicina mostravam alta freqüencia da transferência ( 84 a 95\%) do caráter síntese de actinomicina entre os recombinantes prototróficos, sendo que nenhum recombinante protọtrófico produtor de actinomicina foi detectado na fusão com linhagens auxotróficas e não produtoras. Em recente investigação, KINASHI \& SHIMAJI (1987) isolaram, através de eletroforese ortogonal, três plasmídios lineares de $520 \mathrm{~kb}, 560 \mathrm{~kb}$ e $580 \mathrm{~kb}$ em s. parvulus ATCC 12434, entretanto ainda não é conhecido se são encontradós nestes plasmídios genes para a síntese de actinomicina.

Situação conflitante tem sido observada com os estudos realizados em S. kasugaensis, produtor de kasugamicina e aureotricina. Investigações iniciais realizadas por OKANISHI et alii (1970) e OKANISHI (1979, 1980) postulam * a ocorrência de genes estruturais biossintéticos sobre elementos extracromossômicos. Contudo, trabalho realizado posteriormente por FURUMAI et alii (1982) demonstra que pelo menos em alguns clones obtidos de protoplastos regenerados, os genes estruturais para biosíntese de aureotricina são codificados cromossomalmente. Igualmente confusas são as observações 
realizadas com a linhagem de Se fradiae produtora de tilosina: BALTZ (1980) atribui a ocorrência do gene Tyl A sobre cromossomo, enquanto que trabalho posterior do mesmo autor (BALTZ, 1982) postula que genes estruturais estão em plasmídio, embora nenhum CCC (Circular Covalent Closed) DNA tenha sido detectado.

Estes estudos inconclusivos decorrem possivelmente de rearranjo cromossômico ocasionado por deleção e amplificação nestes microrganismos que alteram muitas propriedades fenotípicas.

o uso de técnicas mais sofisticadas como OFAGE e a clonagem molecular, poderão avançar estas investigações e esclarecer estas questões fundamentais para. o melhoramento de linhagens de importância industrial.

2.4. Novos métodos para obtenção de antibióticos

As recentes investigações da tecnologia do DNA recombinante mostram que a manipulação genética da via biossintética de microrganismos produtares de antibióticos conduz ao aparecimento de novas éstruturas antimicrobianas, aumento de produtividade, estabilização de produção, alteração na regulação fisiológica e também eliminação de reações indesejáveis. 
A biossíntese mutacional ou mutassíntese constitui um dos primeiros métodos para obtenção de novos antibióticos. DAUM \& LEMKE (1979) observaram que linhagens mutantes bloqueadas na via biossintética foram alimentadas durante a fermentação com precursores não comuns à reação, originando a produção de novos análogos estruturais. Baseados nestas experiências, mutantes idiotróficos de s. fradiae produziram novos análogos de neomicina.

\subsubsection{Fusão de protoplastos}

Os protoplastos constituem um instrumento indispensável nas pesquisas genéticas de Streptomyces, não apenas pela transformação de DNA, mas também porque podem ser utilizados em processo de fusão entre parentais cujo sistema conjugacional não é conhecido ou detectável.

As técnicas de formação e regeneração de protoplastos em estreptomicetos foram utilizadas a partir dos relatos de SAGARA et alii (1971) e OKANISHI et alii (1974). Subsequentemente, técnicas e métodos melhorados para regeneração de protoplastos foram introduzidos por HOPWOOD et alii (1977), BALTZ (-1978) e SHIRAHAMA et alii (1981). Esses trabalhos são fundamentados no tratamento coin enzima lítica, usualmente lisozima, de células que preferencialmente são pré-cultivadas em um meio com gljucina para facilitar a digestão da parede celular. 
Fusão de protoplastos em células animais e de plantas foi um processo utilizado muito antes de se realizar fusão microbiana. O progresso da fusão de protoplasto foi mais rápido com células microbianas em decorrência da fácil manipulação e de crescimento rápido.

FERENCZY et alii (1972) realizaram a primeira fusão de protoplastos em condições controladas com fungo filamentoso, Geotrichum candidum, utilizando para o processo de fusão força centrífuga para aglutinação dos protoplastos.

Somente após a descoberta de que o polietileno glicol (PEG) atuava como agente fusogênico em protoplastos de plantas (KAO \& MICHAYLUK, 1974; WALLIN et alii, 1974) é que este composto foi usado com sucesso em experimentos com bactérias Gram-positivas. FODOR \& ASTOLFI (1976), usando mutantes auxotróficos duplos de Bacillus megaterium e usando PEG, obtiveran produtos de fusão nutricionalmente complementares. Em seguida, HOPWOOD et alii (1977) realizaram fusão de protoplastos com diferentes linhagens de streptomyces utilizando PEG e Dimetil sulfóxido (DMSO) com sucesso. A partir de então; a transferência de genes entre streptomuces de importância econômica tornou-se viável, principalmente entre linhagens onde o sistema de conjugação não estava bem estabelecido. 
Os protoplastos também são excelentes receptores de plasmídio exógeno ou DNA de bacteriófago, servindo como eficiente sistema de transformação e transfeção. O primeiro trabalho de transformação por DNA plasmidial em bactérias Gram-positivas foi realizado por BIBB et alii (1978) utilizando Streptomyces, seguido do relato de CHANG \& COHEN (1979) com Bacidjus. Estas descoberłas foram de grande importância, principalmente em Streptomyces, porque nenhum sistema de transformação era conhecido em linhagens de interesse comercial.

A aplicação da fusão de protoplastos em microrganismos de interesse econômico tem se mostrado eficaz para obtenção de novos antibióticos, para os programas de melhoramento de linhagens importantes industrialmente e também tem contribuído para melhor entender as vias do metabolismo secundário na biossíntese de antibióticos.

A fusão interespecífica entre S. teniimariensis prodútor de istamicina e $\mathbf{S}$. Eriseus produtor de estreptomicina foi relatada por HOTA et alii (1985), YAMASHITA et alii (1985) e originou um recombinante que produzia um novo antibiótico, indolisomicina, que era diferente dos aminoglicosídicos produzidos pelos parentais. YOUXIA et alii (1986) também observaram um novo antibiótico em um recombinante obtido da fusão entre $S_{\text {. }}$ 
gingfengmvceticus e $S$ hrgroscopicus var. jinggangensis. A nova substância designada RVA18 era distinta daquelas produzidas pelos parentais, sendo sugerida pelos autores a obtenção de um antibiótico "híbrido".

IKEDA et alii (1983) observaram que linhagens de S. ambofaciens e s. fradiae produtores, respectivamente, de espiramicina e de tilosina, aumentaram a produtíividade em cerca de 3,6 vezes em relação à linhagem original após regeneração de protoplastos. Igualmente ARAUJO et alii (1984/85) observaram que protoplastos regenerados, de S. capoamus IA-M3122 aumentaram em cinco vẹzes a produção de ciclamicina em relação à linhagem parental. Segundo IKEDA et alii (1983) e KURYLOWICZ et alii (1987), o aumento da produção de antibiótico por protoplastos regenerados pode ser ocasionado por variações genéticas proporcionadas pela liberação de plasmídios ligados às proteínas das membranas, causando mudanças intracelulares que são expressas na variação da produção de antibióticos.

OCHI (1982), com o objetivo de determinar a transferência da propriedade de. produção de actinomicina $\left(\right.$ act $\left.^{+}\right)$em $S_{\text {, antibioticus e }}$ s parvulus, realizou fusăo intraespecífica dentro destas linhagens e detectou, respectivamente, $68 \%$ e $48 \%$ de transferência desta propriedade, após fusão de protoplastos. 
A seleção de linhagens utilizadas para recombinação por fusão de protoplastos deve ser conduzida com base no conhecimento da via biossintética de linhagens produtoras de compostos ativos. Segundo NORMANSELL (1982), - sucesso para obtenção de um novo antibiótico por fusão de protoplastos depende do uso de linhagens que produzam antibióticos pertencentes ao mesmo grupo estrutural. Isto provavelmente aumenta a chance de que uma enzima introduzida em um novo hospedeiro encontre um substrato quimicamente diferente do seu substrato normal, porém seja capaz de convertê-lo a um análogo estrutural novo. HOPWOOD (1981b) enfatiza que a informação genética estrutural para a formação do novo produto pode se originar de uma única linhagem pela ativação de genes silenciosos ("silent genes") ou, ainda, genes estruturais procedem de ambos os parentais para produzir um antibiótico "híbrido". A hibridização entre linhagens da mesma espécie ou grupos de espécies relacionados constitui uma ótima estratégia para descobrir novos antibióticos através da eliminação da regulação do gene estrutural que passa a se expressar em outra linhagem.

\subsubsection{Tecnologia do DNA recombinante}

Os recentes avanços da clonagem molecular de genes biossintéticos de antibióticos em Streptomyces 
mostram que é possível obter novos antibióticos através da tecnologia do DNA recombinante promovendo assim um grande avanço para a Biotecnologia.

HOPWOOD et alii (1985a) desenvolveram várias estratégias para clonagem molecular e análises de genes em Streptomyces - Os vetores foram, construídos a partir de plasmídios endógenos de streptomvces pela inserção de determinantes de resistência a antibióticos obtidos de linhagens produtoras destes metabólitos (HOTA et alii, 1985). Estes vetores com resistência a tioestrepton (tsr) de S. azureus ATCC 1492; com resistência a neomicina (aminoglicosídeofosfo-transferase) de $s$, fradiae ATCC 10745; com resistência a viomicina (viomicinatransferase) de $S_{\text {s }}$ vinaceus NCIB8852 e com resistência a higromicina de S. hvgroscopicus foram desenvolvidos para seleção de clones ou para reconhecer clones pela inativação insercional quando presente como uma segunda marca (THOMPSON et alii, $1980 ; 1982 \mathrm{a} ; 1982 \mathrm{~b}$; MALPARTIDA et alii, 1983).

A aplicação da genética molecular e da engenharia genética em streptomyces tem se mostrado eficiente em levar fragmentos de DNA de uma linhagem doadora para uma linhagem receptora estável. Com o domínio de todas estas técnicas tem sido possível clonar genes biossintéticos e de resistência de vários antibióticos: bialofos, metilenomicina, estreptomicina, actinorrodina, 
entre outros (MURAKAMI et alii, 1986; CHATER \& BRUTON, 1985 ); OHMUKI et alii, 1985; DISTLER et alii, 1987; TOHYAMA et alii, 1987; MALPARTIDA \& HOPWOOD, 1984, 1986).

Estas investigações mostraram que genes biossintéticos de antibióticos se encontram formando um agregado gênico, não estando, portanto, espalhados aleatoriamente no cromossomo, como era a idéia original.

MALPARTIDA \& HOPWOOD (1984) desenvolveram um

- vetor piJ2303 contendo genes biossintéticos de actinorrodina de $s$, coelicolor que, transformava e complementava mutantes não produtoras de actinorrodina, bem como dirigia a síntese desse antibiótico em $S$ parvulus não produtor de actinorrodina.

Actinorrodina, como granaticidina e medermicina, pertence ao grupo químico isomanequinona; os três são derivados biossinteticamente de unidades de acetato através da via poliacetídica (GORST-ALLMAN et alii, 1981).

A partir destes conhecimentos HOPWOOD et alii (1985b) utilizaram o clone piJ2303, bem como subclones que conduziam diferentes unidades transcricionais da região act e introduziram por transformação em diferentes linhagens de Streptomvces produtoras de medermicina e granaticina. Entre os clones selecionados pela transformação da linhagem produtora de medermicina observaram colonias que formavam pigmento púrpura e 
produziam medermicina e um novo composto denominado mederrodina, enquanto que a transformação da linhagem produtora de granaticina originou culturas com pigmento azul-púrpura, que produziam granáticina e um novo composto, dihidrogranaticina.

Segundo HOPWOOD et alii (1985b), estes novos produtos surgem de vias biossintéticas híbridas pela interação de enzimas codificadas em genes estruturais das duas linhagens e não pela ativação de genes silenciosos na linhagem receptora.

A construção de linhagens híbridas pela engenharia genética mostra a grande utilidade desta técnica como um instrumento valioso na descoberta de novos antibióticos mais eficientes terapeuticamente. 


\section{MATERIML E METODOS}

\subsection{Linhagens utilizadas}

Linhagens

Origens

Fendtipe relevante

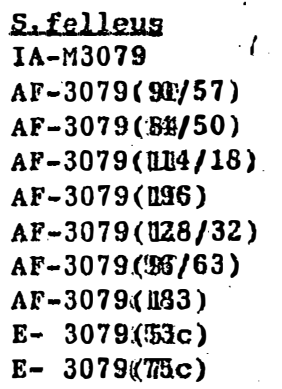

selvagem

tratamento por acriflavina tratamento por acriflavina tratamento por acriflavina tratamento por acriflavina tratamento por acriflavina tratamento por acriflavina tratamento por acriflavina espontânea espontânea

\section{S, regensis \\ IA-M $305: 3$ \\ $A F-3053((53 / 5)$ \\ $A F-3053(1141 / 2)$ \\ $A F-3053(134 / 8)$ \\ $\mathrm{AF}-3053(105 / 4)$ \\ $A F-3053$ (128B) \\ E $-3053(6.6 \mathrm{c})$}

\section{S, paryulons}

IA-3042:(6/1)

$A F-3042((6 / 1)$

$A F-3042(48 / 2)$

Recombiontes

Sma, Smbr. Smc,

Smcd, Simce

S. Livigans

S, liyidans piJ702 (5.8kb)

\section{S. lixidans} piJ943 $(20,6 \mathrm{~kb})$

5._ixidans $\operatorname{piJ303}(10,7 \mathrm{~kb})$

\section{selvagem}

tratamento por acriflavina tratamento por acriflavina tratamento por acriflavina tratamento por acriflavina tratamento por acriflavina espontânea

selvagem

tratamento por acriflavina tratamento por acriflavina

fusão de protoplastos S. felleus IA-M3079 $x A F-3079(90 / 57))$

John Innes Institute

John Innes Institute

John Innes Institute

John Innes Insititute produtora de actinomicina prototrófica act prototrófica actprototrófica actfenilalanina phe fenilalanina phe fenilalanina pheprototrófica act ${ }^{++}$ prototróf ica act prototrófica act"

produtora de actonowicina prototrófica actprototrófica actprototrófica actprototrófica actprototrófica act+s prototrófica act-.

produtora de actinomicina prototróficá actprototrófica act-

produz antifúngico ade-

$\operatorname{str} r^{R}$

Thio ${ }^{R}$ Tyr $^{*}$

Thio ${ }^{\mathrm{R}}$

Thio $^{R}$ 
3.2. Meios de Cultura

3.2.1. Meio de esporulação (MR) (KURYLOWICZ) ${ }^{1}$

Este meio consiste de trato de levedura $0,4 \%$, extrato de malte $0,8 \%$, glicose $0,4 \%$. Ajustado a $\mathrm{pH}$ 6,8-7,0 com solução de hidróxido de söđỉio.

3.2.2. Meio mínimo (PONTECORVo alii, 1953)

o meio mínimo consiste dé nitrato de sódio $0,6 \%$ dihidrogênio fosfato de potássio $0,15 \%$, cloreto de potássio $0,05 \%$, sulfato de magnésio eqtahidratado $0,05 \%$, sulfato ferroso $0,001 \%$, sulfato de zimco $0,001 \%$, glicose $1,0 \%$, ágar $1,5 \%$ pH 6,8 a.justado com hlidróxido de sódio a $40 \%$.

3.2.3. Meio completo sólido (potenconvo et alii, 1953, modificado por AGEEDO \& COSTA, 1973)

Ao meio mínimo (fem: 3.2 .2 ) foram adicionados peptona $0,2 \%$, caseína hidrolisada $0,15 \%$, extrato de levedura $0,05 \%$, solução dé vitaminas $0,1 \mathrm{ml}$ (v/v) (item 3.3.1). Ajustado o pH para6f8 $\operatorname{com}$ hidróxido de sódio a $40 \%$.

1 KURYLOWIZ, W. (Instituto de Higiene,Värsóvia-Polônia) Comunicação Pessoal, 1982 . 


\subsubsection{Meio. nutriente ágar (NA)(Difco)}

O meio desidratado $(2,3 \%)$ foi preparado, distribuído volumes de $300 \mathrm{ml}$ e autoclavado.

\subsubsection{Meio "Tryptic Soya Broth" (TSB) (Difco) \\ o meio hidratado foi distribuído em frascos} Erlenmeyer de $125 \mathrm{ml}$ com $25 \mathrm{ml}$ de meio e autoclavado.

\subsubsection{Meio de Sabouraud}

Este meio consiste de peptona $1,0 \%$, glicose 4,0\%, extrátos de carne $0,35 \%$, cloreto de sódio $0,75 \%$. $\mathrm{pH}$ ajustado parm $6,8-7,0$ com $\mathrm{NaOH}$.

\subsubsection{Meio $R_{2} Y E$ (THOMPSON et alii, 1980)}

Sacarose 0,3M, sulfato de potássio $0,025 \%$, cloreto de magnésio $0,6 \mathrm{M}$, glicose $1,0 \%$, caseína hidrolisada $0,01 \%$, soluçæ̃o de elementos traços $(3.3 .12) 0,2 \%(v / v)$, extrato de levedura $0,5 \%$, tampão TES 0,25M. Em Erlenmeyer de $250 \mathrm{ml}$ foram colocados $2,2 \mathrm{~g}$ de ágar (Difco), adicionados $100 \mathrm{ml}$ da solução acima, sendo o meio autoclavado. No momento de usar, foi adicionado $1,0 \mathrm{ml}$ de fosfato ácido de potássio $(0,5 \%), 0,4 \mathrm{ml}$ de cloreto de 
cálcio (5M), 1,5 $\mathrm{ml}$ de L-prolina (20\%) e $0,7 \mathrm{ml}$ de hidróxido desódio (1N).

3.238. Meio semi-sólido (overlay) (IKEDA et alii, 1983 )

Gelatina $0,1 \%$, sacarose $0,3 \mathrm{M}$, cloreto de magnésio 0,6 cloreto de cálcio 0,02M, tampão HEBES foi substituído tampão TES $25 \mathrm{mM}$, ágar (Difco) 0,65\%.

3.2 Meio ISP1 Triptona-extrato de levedura (PRIDHAM \& GOTTLIEB, 1948).

Triptona $0,5 \%$ e extrato de levedura $0,3 \%$. 0 pH do meio fori ajustado para 7,0-7,2; em seguida, o meio foi distribúíto em porções de $25 \mathrm{ml}$, para Erlenmeyers de $125 \mathrm{ml}$.

3.2.10. Meio ISP2 - Extrato de levedura-extrato de malte-ágar (PRIDHAM et alii, 1956-57)

Extrato de levedura $0,4 \%$, extrato de malte $1,0 \%$, glicos $0,4 \%$. $0 \mathrm{pH}$ foi ajustado para 7,3 e então adicionado agar (Difco) 2,0\%, 0 meio foi autoclavado e distribuído em porções de $25 \mathrm{ml}$ por placa de Petri. 
3.2.11. Meio ISP3 - Aveia-ágar (Difco) (KÜSTER, 1959)

0 meio desidratado $(2,2 \mathrm{~g} \%)$ foi preparado e o $\mathrm{pH}$ ajustado para $6,8-7,0 \mathrm{com} \mathrm{NaOH} 40 \%$, sendo autoclavado e distribuído em porções de $25 \mathrm{ml}$ por placa de Petri.

$$
\begin{aligned}
& \text { 3.2.12. Meio ISP4 - Amido-sais minerais-ágar } \\
& \text { (Difco) (SHIRLING \& GOTTLIEB, 1966) } \\
& \text { o meio desidratado }(3,7 \mathrm{~g} \%) \text { foi procedido }
\end{aligned}
$$

como no item $3 \cdot 2 \cdot 11$.

$$
\begin{aligned}
& \text { 3.2.13. Meio ISP5 - Glicerol-asparagina-ágar } \\
& \text { (Difco) }(\text { SHIRLING \& GOTTLIEB, 1966) }
\end{aligned}
$$

O meio desidratado $(2,2 \mathrm{~g} \%)$ foi adicionado de $1 \mathrm{~g} \%$ de glicerol e procedido como no item 3.2 .11 .

3.2.14. Meio ISP6 - Peptona-extrato de leveduraferro-ágar (Difco) (TRESNER \& DANGA, 1958)

Ao meio desidratado peptona iron-ágar $(3,6 \mathrm{~g} \%)$ foi adicionado $0,1 \mathrm{~g} \%$ de extrato de levedura, sendo então fervido para liquefazer o ágar e, em seguida, distribuido em tubos e autoclavado. 
3.2.155. Meio ISP7 - Tirosina- ágar (SHINOBU, 1958)

O meio desidratado $(2,3 \mathrm{~g} \%)$ foi fervido para liquefação do ágar, distribuído em tubos e autoclavado.

\subsubsection{6\%. Meio ISP9 - Para fontes de carbono (PRIDHAM \& GOTTLIEB, 1948 modificado por SHIRLING \& GOTTLIEB, 1966)}

Este meio, após autoclavação, foi adicionado assepticamente de diferentes fontes de carbono na concentração de $1 \%$. As fontes de carbono: glicose, Larabinose, sacarose, D-xilose, I-inositol, D-manitol, Dfrutose, rammose e rafinose foram esterilizadas com,éter etílico livre de acetona durante três dias consecutivos. Após evaporagão de todo o éter, cada um foi adicionado a um Erlenmeyer comtendo o meio ISP-9 e distribuído em tubos.

3.2.1\%. Meio de tolerância a cloreto de sódio (PRIDHAM et alii, 1956/1957)

Meio ISP2 (iten 3.2.10). A quatro diferentes porções deste meio foi adicionado cloreto de sódio para as concentrações de $4 \%, 7 \%, 10 \%$ e $13 \%$. 
3.2.18. Meio de gelatina- ágar

Peptona $0,5 \%$, extraco de carne $0,3 \%$, gelatina $0,4 \%$, ágar (Difco) $1,5 \%$; $\mathrm{pH}$ àjṣtado para 7,0 .

3.2.19. Meio de Produção de

Farinha de soja $2,0 \%$, direto de sódio $0,5 \%$, glicose $-2,0 \%$, carbonato de cálcio $0,2 \%, \mathrm{pH}$ 6,8-7,0 ajustado com $\mathrm{NaOH} 40 \%$.

3.2.20. Esterilização dos meä̀aš

Todos os meios forasesterilizados por autoclavação a $121^{\circ} \mathrm{C}$ durante 15 minutas:

3.3. Soluções utilizadas

3.3.1. Solução de vitaminas

Biotina

$0,2 \mathrm{mg}$

Acido- p -aminobenzóico

$10,0 \mathrm{mg}$

Tiamina $50,0 \mathrm{mg}$

Piridoxina $50,0 \mathrm{mg}$

Ac: nicotínico $100,0 \mathrm{mg}$

Riboflavina $100,0 \mathrm{mg}$

Agua destilada $100,0 \mathrm{ml}$ 
A solução foi aqueciida em banho-maria durante 15 minutos e mantida em frasco escuro no refrigerador a $4^{\circ} \mathrm{C}$.

3.3.2. Solução de caseína hidrolisada

Caseína hidrolisada $100,0 \mathrm{mg}$

Agua destilada esterilizada $10,0 \mathrm{ml}$ - A solução foi aquecida por 15 minutors en banho-maria e mantida no refrigerador a $4^{\circ} \mathrm{C}$.

3.3.3. Solução de ácido nucleixo:

Solução A: ácido nucle.io de levedura $2,0 \mathrm{~g}$ em $15 \mathrm{ml}$ de ácido clorídrico $1 \mathrm{~N}$.

Solução B: ácido nucleicoode levedura $2,0 \mathrm{~g}$ em hidróxidodér sódio $1 \mathrm{~N}$.

Cada solução foi aquedilà: separadamente em banho-maria durante 20 minutos. A segurry foram misturadas e - $\mathrm{pH}$ ajustado parả 6,0 com $\mathrm{NaOH} 140 \%$. A mistura foi filtrada e o volume completado para $40,0 \mathrm{ml}$ com água destilada. 
3.3.H. Soluções-estoque dos suplementos adicionados ao meio mínimo

O estoque dos suplementos foi preparado pela adição de cadia um deles em água destilada esterilizada. As soluções føam aquecidas em banho-maria e conservadas no refrigerador..

3.3..5 Solução-estoque de acrilamida (30\% de acrilamida e $0,8 \%$ de $N^{\prime}, N^{\prime}$-metileno-bisacrilamida) (LAEMMLI, 1970)

Acrilamida $75,0 \mathrm{~g}$, bis-acrilamida $2,0 \mathrm{~g}$ dissolvidas $250 \mathrm{ml}$ de água desmineralizada. A solução foi filtrada e armazenada a $4^{\circ} \mathrm{C}$.

3.3.6. Solução reveladora da atividade esterase ( SHAW \& PRASAD, 1970)

Substratos: - alfa-naftil acetato $1,0 \%$ dissolvido em acetona e água.

- beta-naftil acetato $1 \%$ dissolvido em acetona. Ambas as soluções foram conservadas a $4^{\circ} \mathrm{C}$.

Coloração: "Fast blue RR" $50 \mathrm{mg}$, tris.HCl 0,5 M (pH 7,1) $5,0 \mathrm{ml}$, alfa e beta naftilacetato a $1 \%, 1,5 \mathrm{ml}$, água destilada $43,5 \mathrm{ml}$. 


\subsubsection{Solução Fixadora PAGE}

Esta solução contém $45 \mathrm{ml}$ de metanol, $10 \mathrm{ml}$ de ácido acêtico e $45 \mathrm{ml}$ de água destilada.

Corante: Azul Comassie ("Brillant Blue R250") $50 \mathrm{mg}$ dissolvidos em $50 \mathrm{ml}$ do Fixador PAGE.

3.3.8. Solução de glicina (20\%)

Glicina $(10 \mathrm{~g})$ foi solubilizada para $50 \mathrm{ml}$ com água destilada e em seguida autoclavada.

3.3.9. Solução de sacarose $0,3 \mathrm{M}$

Esta solução foi preparada, distribuída em tubos de ensaio e autoclavada.

3.3.10. Solução de lisozima $(1,5 \mathrm{mg} / \mathrm{ml})$

No momento de usar foi preparada solução de lisozima por dissolução da mesma em tampão $P$ (item 3.4.1.) e esterilizada por filtração.

\section{3 .11 . Solução de PEG $1000(50 \%)$}

Foi autoclavado $1,0 \mathrm{~g}$ de PEG em um tubo de ensaio e no momento de usar adicionado $1,0 \mathrm{ml}$ de tampão $\mathrm{P}^{*}$ (item $3.4 \cdot 1$.$) .$ 
3.3.12. Solução de elementos traços (OKANISHI et alii, 1974)

Cloreto de zinco $40 \mathrm{mg}$; cloreto férrico 200 mg; cloreto de cobre $10 \mathrm{mg}$; cloreto de'manganês $10 \mathrm{mg}$; borato disső̈dico $10 \mathrm{mg}$; molibdato de amônio $10 \mathrm{mg}$. A solução preparada para um litro de água destilada e conservada no refrigerador.

3.3.13. Solução de dodecilsulfato de sódio (SDS) $1,5 \%$

Solução estoque de $\operatorname{sDS}$ a $10 \%(\mathrm{p} / \mathrm{v})$ foi diluída em tampão TE (item 3.4.3.) e ajustada a pH 12,45 com solução de hidróxido de sódio $10 \mathrm{~N}$.

\subsubsection{Solução fenol-clorofórmio}

Volumes de fenol e clorofórmio foram utilizados na proporção de $1: 1$ e adicionado $0,05 \%$ de 8hidroxiquinolina. Esta solução foi saturada com tris-HCl 50 . $\mathrm{mM}(\mathrm{pH} 8,0)$.

3.3.15. Solução de bicloreto de mercúrio (15\%)

Bicloreto de mercúrio foi dissolvido em ácido clorídrico a $20 \%$. 
3.3.11. Soluções-estoque de antibióticos utilizados Actinomicina $\mathrm{D} 10,0 \mathrm{mg} / \mathrm{ml}$ em metanol; Anfotericina Eritromicina, Estreptomicina, Gentamicina, Penicilina Rifampicina $10,0 \mathrm{mg} / \mathrm{ml}$ em água destilada e esterilizadas por filtração; Tetraciclina $10 \mathrm{mg} / \mathrm{ml}$ em $50 \%$ de etanol; Tioestrepton em Dimetilsulfóxido (DMSO) 5,0 $\mathrm{mg} / \mathrm{ml}$.

\subsection{Tampões}

3.4.1. Tampão P (protoplastos) (OKANISHI et alii, 1974)

Sacarose $0,3 \mathrm{M}$, dihidrogênio fosfato de potássio 0,005\%, sulfato de potássio 0,025\%, cloreto de magnésio 0,01M, cloreto de cálcio 0,025M, TES (N-tris (hidroximetil)(metil-2- ácido aminoetanosulfônico) 0,25M, solução de elementos traços $0,2 \%$ (v/v) (item 3.3.12.).

3.4.2. Tampão borato (TEB)

Tris-base $89 \mathrm{mM}$, ácido bórico $89 \mathrm{mM}$, EDTA 20 $\mathrm{mM} ; \mathrm{pH} 8,0$. 


\subsubsection{Tampão TE}

Tris-HCl 50mM, EDTA $(\mathrm{pH} 8,0) 20 \mathrm{mM}(\mathrm{pH} 8,0)$.

3.4.4. Tampão da amostra para gel agarose

Azul de bromofenol $0,1 \%$, Ficoll $20 \%(\mathrm{p} / \mathrm{v})$ dissolvido em TEB $3 \mathrm{x}$.

3.4.5. Tampão do gel separador (LAEMMLI, 1970)

Tris-base 45,75\% em água desmineralizada. A solução foi titulada para pH 8.9 com ácido clorídrico concentrado, em seguida o volume foi completado a $100 \mathrm{ml}$ e filtrado.

3.4.6. Tampão do gel empilhador (LAEMMLI, 1970)

Tris-base 7,475\% em água desmineralizada e em seguida titulada com $\mathrm{HCl} 1 \mathrm{~N}$ para $\mathrm{pH} 6,8$, procedendo-se igualmente como a solução anterior.

3.4.7. Tampão eletrólito ou tris-glicina pH 8,9 ( LAEMMLI, 1970)

Tris-base $63,2 \mathrm{~g}$, glicina $39,9 \mathrm{~g}$ foram dissolvidos para um litro de água desmineralizada. O tampão 
foi filtrado e armezenado a $4^{\circ} \mathrm{C}$. No momento do uso diluído $1: 10$ em água desmineralizada.

3.4.8. Tampão da amostra para o gel poliacrilamida

Este tampão consistiu de 5,0 ml de glicerol, $2,5 \mathrm{ml}$ do tampão do gel empilhador (item 3.4 .6 ), 2,5 mg de azul de bromofenol. O volume completado para $25 \mathrm{ml}$ com água desmineralizada e armazenado a $-20^{\circ} \mathrm{C}$.

3.5. Manuteņ̧ão

As linhagens de streptomyces, foram cultivadas em tubos inclinados com meio de esporulação (ME) (item 3.2 .1 ), incubadas a $30^{\circ} \mathrm{C}$ por 5 a 7 dias. Em seguida foram conservadas a $4^{\circ} \mathrm{C}$ ou usadas para a preparação da suspensão de esporos.

3.5.1. Suspensão de esporos (HOPWOOD et alii, $1985 a)$

Suspensões foram preparadas a partir de culturas bem esporuladas, usando-se água destilada esterilizada e Tween 80 a 0,01\%. Com auxílio de uma pipeta, os esporos foram desagregadas e a suspensão filtrada em [i.t.tro com quatro camadas de tecido de nylon esterilizadas. 
Em seguida este material foi centrifugado a $5.000 \mathrm{rpm} / 10$ minutos. O sedimento ressuspendido em glicerol a $20 \%$, de modo a conter $10^{8}$ a $-10^{9}$ células/ml. Esta suspensão foi mantida a $-20^{\circ} \mathrm{C}$.

3.5.2. Manutenção dos microrganismos-teste

Para os ensaios antimicrobianos foram utilizados Bacillus subtilis 9-IA-16, Staphylococcus aureus IA01 e Escherichia coli cultivados em tubo inclinado de nutriente ágar (Difco) (item 3.2.4) por 24 horas a $37^{\circ} \mathrm{C}$, enquanto que Candida albicans IBB-50 e Neurospora crassa IA-2084 foram cultivados em tubo inclinado de Sabouraudágar (Difco) (item 3.2 .6 ) a $30^{\circ} \mathrm{C}$ por 24 e 48 horas, respectivamente.

3.5.3. Suspensão microbiana para os ensaios

De cada amostra de bactéria, fungo ou levedura, após o período de crescimento, foi feita suspensão pela adição de $4 \mathrm{ml}$ de salina e a suspensão diluida de modo a se obter uma suspensão homogênea, no momento da realização do teste. 
3.5.4. Leitura de cores

A leitura das cores do micélio aéreo, reverso e pigmento solúvel ‘foi realizada através do dicionário de cores adotado pelo International streptomyces Project: Color Harmony Mannual (JACOBSON et alii, 1948) e da Tabela de cores de Baumanns Farbtonkarte Atlas I (PRAUSER, 1964).

3.6. Tratamento com agente intercalante

3..6.1. Linhagens

S. felleus IA-M3079; S. regensis IA-M $3053^{\circ} \mathrm{e}$ S. parvulus IA-M3042.

\subsubsection{Cultivo}

Frascos Erlenmeyer de $125 \mathrm{ml}$ contendo $25 \mathrm{ml}$ de "Tryptic Soya Broth" (item 3.2.5) foram adicionados de concentrações variadas de acriflavina ( 0 a $40 \mu \mathrm{g} / \mathrm{ml})$ e inoculados com $0,2 \mathrm{ml}$ da suspensão de esporos (item 3.5.1). Os cultivos foram mantidos sob agitação a 160-180 rpm durante 3 dias a $30^{\circ} \mathrm{C}$.

A acriflavina foi utilizada com base nos trabalhos de OCHI \& KATZ (1978) e OGURA et alii (1986). 
3.6.3. Determinação da concentração de acriflavina

Para avaliação do efeito da acriflavina sobre o crescimento das diferentes linhagens de Streptomvces foi adotada a metodologia preconizada por OGURA et alii (1986). O percentual de inibição foi determinado através do volume de sedimentação da massa celular. Alíquotas de $5,0 \mathrm{ml}$ do cultivo controle foram centrifugadas a $4.000 \mathrm{rpm} / 5$ minutos (centrífuga excelsa Baby) e o volume da massa celular considerado como $100 \%$ de crescimento.

\subsubsection{Ensaio antimicrobiano}

A massa celular obtida do tratamento por acriflavina foi finamente homogeneizada em homogeneizador de tecido manual, seguindo-se de diluições sucessivas e plaqueamento em meio ME (item 3.2.1). Após crescimento individual das colonias, estas foram retiradas com um furador de rolha de $4 \mathrm{~mm}$ de diâmetro e colocadas sobre placas de NA (item 3.2.4), onde havia sido espalhada com alça de Drigalski uma suspensão bacteriana de Bacillus subtj]is (item 3.5.3). Estas placas foram para estufa de $37^{\circ} \mathrm{C}$ por 18-24 horas, quando então foi observada a formação ou nã̃o de halos de inibição. 
Usando a mesma metodologia, com modificações no meio de culturà (item 3.2.6) e utilizando discos de papel embebidos nos líquidos fermentados (item 3.2.19) pelos setores segregantes, foi ensaiada a atividade antimicrobiana para Candida albicans IBB50, Neurospora crassa IA-2084, Staphylococcus aureus IA-01, Escherichia coli. N, Mycobacterium smegmatis.

3.7. Extração de DNA plasmidial

3.7.1. Linhagens utilizadas

S. felleus IA-M3079; AF-3079(90/57); IA$3079(53 c)$ e linhagens-padrão de S. lividans piJ702 e piJ943.

3.7.2. Cultivo

o meio de cultura e as condições de cultivo como descrito no item 3.6.2. Para as linhagens-padrão de S. lividans piJ702 e piJ943 foi adicionado tioestrepton $(5,0 \mu \mathrm{g} / \mathrm{ml})$. 
3.7.3. Obtenção de massa celular

Aproximadamente $1,0 \mathrm{ml}$ do crescimento foi centrifugado em uma microcentrífuga (Spin II), para obtenção de $200 \mathrm{mg}$ de células úmidas.

3.7.4. Extração (mini-preparação)

A extração foi realizada por lise alcalina segundo a metodologia de KADO \& LIU (1981) modificada. Foram usados 0,2 a 0,3 g de células úmidas (item 3.7 .3 ), lavadas com sacarose $0,3 \mathrm{M}$ e ressuspendidas em $100 \mu \mathrm{l}$ de tampão TE (item 3.4 .3 ) contendo $2,0 \mathrm{mg} / \mathrm{ml}$ de lisozima. Este sistema foi incubado a $37^{\circ} \mathrm{C}$ por 30 minutos com agitação ocasional. Em seguida foram adicionados $400 \mu l$ de dodecilsulfato de sódio (SDS) (item 3.3.13), sendo o sistema agitado em vortex e incubado a $65^{\circ} \mathrm{C} / 15$ minutos. Após resfriamento, o material foi tratado com fenolclorofórmio (item 3.3.14) por 3 vezes e o sobrenadante foi usado para aplicar no gel agarose.

3.7.5. Eletroforese em gel agarose (horizontal)

Minigéis foram preparados com agarose tipo II (Sigma) na concentração de $0,8 \%$ em TEB (item 3.4.2) contendo brometo de etídio na concentração de $0,5 \mu \mathrm{g} / \mathrm{ml}$. As amostras misturadas ao tampão (item 3.4.4.) foram aplicadas 
no gel e em seguida realizada a corrida por aproximadamente 60 minutos (15 v/cm). Para a corrida foi utilizado tampão TEB (item 3.4 .2 ). Os géis foram revelados no transiluminador UV, fotografados com câmara acoplada com filtro alaranjado e filme panatomic $X$ (Kodak) ASA 32 .

3.8. Caracterização de plasmídio conjugativo pela formação do fenótipo "pock"

3.8.1. Linhagens utilizadas

- S. felleus IA-M3079; S. regensis IA-M3053;

S. parvulus IA-M3042; S. Lividans piJ303 e a lińnhagem testadora s. Lividans TK24 (strR).

\subsubsection{Cruzamento com S. Lividans TK24}

Os cruzamentos foram realizados a partir de culturas bem esporuladas de S. Lividans TK24 strR e das linhagens em estudo, bem como de S. Lividans piJ303 como controle positivo. Foram misturados $0,05 \mathrm{ml}$ de uma suspensão de esporos de S. lividañs com 0,05 $\mu \mathrm{l}$ da suspensão de esporos de cada linhagem. Os esporos foram espalhados sobre a superfície de agar ME inclinado (item 3.2.1) e incubados durante 5 a 7 dias. Decorrido o período 
de incubação foram preparadas, a partir de cada cruzamento, suspensões esporógẻnas como no item 3.5 .1 .

\subsubsection{Expressão do fenótipo "pock"}

A partir das suspensões de esporos de cada cruzamento foram realizadas diluições seriadas até $10^{-3}$ e colocado $0,1 \mathrm{ml}$ sobre a superfície de placas contendo meio

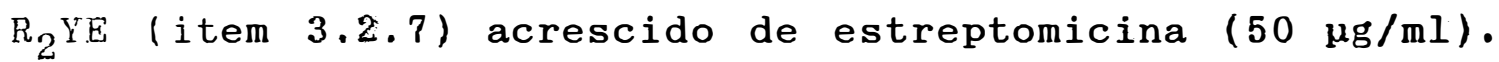
Em seguida $0,05 \mathrm{ml}$ de uma densa suspensão de esporos $\left(10^{9}\right.$ esporos/mIl de $\underline{S}$ lividans TK24 foram adicionados ao inóculo anterior e espalhados com alça de Drigalski sobre a superfície do meio, sendo as placas incubadas a $30^{\circ} \mathrm{C}$ por 72 horas. A cada 24 horas foram realizadas observações com lupa estereoscópica (Olympus. Modelo CHS/CHT). Zonas circulares de inibição do micélio aéreo caracterizam a expressão do fenótipo "pock". 
3.9. Formação, regeneração e fusão de protoplastos (HOPWOOD et alii, 1985a)

\subsubsection{Linhagens utilizadas}

S. felleus IA-M3079 produtora de actinomicina $\left(a c t^{+}\right)$e a variante $A F-3079(90 / 57)$ não produtora de actinomicina $\left(\operatorname{act}^{-}\right)$.

\subsubsection{Cultivo}

Meio de cultura e condições de cultivo como no item 3.6 .2 . Apenas foi adicionado assepticamente ao meio TSB $0,6 \%$ de glicina (item 3.3 .8 ) e o tempo de cultivo foi de $18-20 \mathrm{~h}$.

3.9.3. Formação de protoplastos (HOPWOOD et alii, $1985 a)$

o crescimento obtido foi centrifugado a $4.000 \mathrm{rpm} / 5 \mathrm{~min}$. e lavado duas vezes com sacarose $0,3 \mathrm{M}$ (item 3.3.9). Em seguida foram adicionados $4,0 \mathrm{ml}$ de Lisozima na concentração de $1,5 \mathrm{mg} / \mathrm{ml}$ em tampão $\mathrm{P}$ (i.tem $3.4 .1)$ e o sistema levado para estufa a $37^{\circ} \mathrm{C}$ durante 20 a 30 minn. Após o período de incubação foi adicionado tampão $P$ e filtrado através de um funil com quatro camadas de tecido de nylon $\mathrm{cm}$ un tubo de ensaio esterilizado. Os protoplastos 
foram obtidos por 'sedimentação através de centrifugação (3000 rpm, 7 minutos) e ressuspensos em $10 \mathrm{ml}$ de tampão P.

\subsubsection{Regeneração de protoplastos}

Visando verificar o percentual de regeneração dos protoplastos, foi utilizada a metodologia de IKEDA et alii (1983) que consiste em adicionar 0,1 ml da suspensão diluída em tampão $P$ até $10^{-6}$ sobre placas com meio $R_{2} \mathrm{YE}$ (item 3.2.7). As placas foram deixadas na câmara de fluxo laminar por 20 minutos para evaporação das gotas de água da superfície. Em seguida os protoplastos foram recobertos com $5 \mathrm{ml}$ de ágar hipertônico semi-sólido (item 3.2 .8 ) fundido e mantido a $45^{\circ} \mathrm{C}$. Igualmente, a suspensão de protoplastos foi diluída em água destilada esterilizada até $10^{-4}$ e $0,1 \mathrm{ml}$ foi semeada sobre meio ME (item 3.2.1) para verificar a formação de células não protoplastizadas. A frequência de regeneração foi calculada pela determinação do número de colônias nas duas condições. A incubação foi a $30^{\circ} \mathrm{C}$ por dez dias.

\subsubsection{Inativação de protoplastos}

Uma suspensão de protoplastos da linhagem de S. felleus IA-M3079 contendo aproximadamente $12,1 \times 10^{8}$ protoplastos/ml foi inativada em banho-maria a $65^{\circ} \mathrm{C}$ durante 
10 minutos. Em seguida os protoplastos foram semeados como no. item 3.9 .4 .

3.9.6. Fusão de protoplastos

A fusão de protoplastos foi realizada utilizando $0,5 \mathrm{ml}$ da suspensão de protoplastos inativados (item 3.9.5) mais $0,5 \mathrm{ml}$ da suspensão de protoplastos da varianté AF3079(90/57) contendo aproximadamente $9,8 \times 10^{8}$ - protoplastos/ml. Para fusão foi usado polietileno glicol (PEG) 1000 a $50 \%$ (item 3.3.11) de acordo com HOPWOOD et alii (1985a). Após 2 minutos do tratamento com PEG a $30^{\circ} \mathrm{C}$ foi adicionado $1,0 \mathrm{ml}$ de tampão $\mathrm{P}$ (item 3.4 .1 ), a suspensão centrifugada e o sedimento ressuspenso suavemente em tampão $P$ seguido da semeadura em meio $R_{2} Y E$ como no item 3.9 .4 . Após 10 dias de cultivo a $30^{\circ} \mathrm{C}$ as colônias regeneradas foram analisadas.

3.9.7. Caracterização dos produtos de fusão

Após a regeneração as colônias foram transferidas para placas com meio ME (item 3.2.1) e os produtos de fusão caracterizados quanto à formação de pigmento e halo de inibição para $B$ e subtjlis rA-16 (item $3.6 .4)$ 
3.10. Estabilização dos setores

Os setores observados após a fusão de protoplastos foram estabilizados em placas com meio ME (item 3.2.1) por inoculação em quatro pontos.

3.11. Caracterização do fenótipo "pock" dos setores segregantes

A metodologia utilizada seguiu a técnica descrita no item 3.8 , sendo analisados os setores segregantes após cruzamento com a linhagem testadora $\underline{\text { s. }}$ lividans TK24.

3.12. Características fisiológicas e morfológicas dos setores segregantes

$3 \cdot 12.1$. Linhagens utilizadas

Os setores segregantes Sma, Smb, Smc, Smcd, Smce e as linhagens S. felleus IA-M3079 e AF3079(90/57).

$3 \cdot 12.2$. Suspensão de esporos

Cultivos bem esporulados de cada linhagèm em tubos com 7 dias foram utilizados para preparar a suspensão 
de esporos pela adição de $3,0 \mathrm{ml}$ de água destilada esterilizada.

\subsubsection{Características fisiológicas}

3.12.3.1. Inóculo lavado para ensaio em fonte de carbono (SHIRLING GOTTLIEB, 1966)

Meio líquido $\operatorname{ISP}_{1}$ (item 3.2.9) foi inoculado com, 0,2 ml de uma suspensão de esporos (item 3.12.2) de cada linhagem e incubado por 48 horas sob agitação de 160$180 \mathrm{rpm}$ a $30^{\circ} \mathrm{C}$. Em seguida a massa celular foi centrifugada, agitada com pérolas de vidro e lavada 3 vezes com solução salina. o sedimento foi ressuspéño em $10 \mathrm{ml}$ de solução salina e utilizado para inocular os tubos com diferentes fontes de carbono.

3.12.3.2. Utilização de fontes de carbono (SHIRLING \& GOTTLIEB, 1966)

Tubos contendo o meio ágar ISP-9 inclinado, com fontes de carbono diferentes (item 3.2.16), foram inoculados com uma gota do inóculo lavado (item 3.12.3.1) e incubados a $30^{\circ} \mathrm{C}$, por 16 dias. As leituras foram realizadas

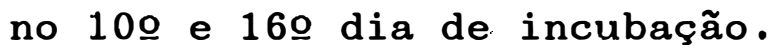




\title{
$3 \cdot 12 \cdot 3 \cdot 3$. Produção de melanina (SHIRLING GOTTLIEB, 1966)
}

A produção de pigmentos melanóides foi verificada nos meios ISP-6 (item 3.2.14) e ISP-7 (item 3.2.15). Uma gota da suspensão de esporos (item 3.12.2) foi adicionada aos tubos em duplicata. Após 2 e 4 dias de cultivo a $30^{\circ} \mathrm{C}$ os tubos com crescimento foram comparados com tubos não inoculados, verificando-se se ocorria a formação de pigmento solúvel marrom a negro.

\author{
3.12.3.4. Hidrólise do amido \\ O estudo desta característica foi realizado
} com o meio ISP-4 (item 3.2.12). Foi feita uma única éstria no centro da placa com suspensão de esporos do item 3.12 .2 e após 5 e 10 dias de cultivo a hidrólise foi verificada através do vapor de iodo.

\section{$3 \cdot 12 \cdot 3 \cdot 5$. Hidrólise da gelatina}

Foi utilizado o meio do item 3.2 .18 , inoculado como no item anterior. Após 5 e 10 dias de cultivo a hidrólise foi verificada utilizando a solução do item $3 \cdot 3 \cdot 15$. 
3.12.3.6. Teste de tolerância ao cloreto de sódio

Foi utilizado o meio do item 3.2 .10 e inoculado como no item $3 \cdot 12.3 .3$. A leitura foi realizada quanto presença de crescimento das linhagens após 7 e 14 dias de cultivo a $30^{\circ} \mathrm{C}$.

\subsubsection{Exigência nutritiva}

Placas contendo meio completo (item 3.2.3) e meio mínimo (item 3.2.2) foram inoculadas pela transferência de esporos de cada linhagem em estudo seguindo-se de incubação por 7 dias a $30^{\circ} \mathrm{C}$. Após o período de incubação e não sendo observado crescimento das colionias em meio mínimo, estas foram ensaiadas quanto à auxotrofia pela inoculação de esporos em placas contendo meio mínimo + 0,1 ml de caseína hidrolisada (item 3.3.2), meio mínimo + $0,1 \mathrm{ml}$ de solução de vitaminas $(3.3 .1)$ e meio mínimo $+0,1$ $\mathrm{ml}$ de solução de ácidos nucleicos (item 3.3.3). A observação de crescimento de colônias em uma destas placas sugeria a deficiência nutricional. A especificação da exigência foi realizada por técnica auxonográfica. 


\subsubsection{Características morfológicas}

Placas contendo os meios ISP-2, ISP-3, ISP-4 e ISP-5 (itens 3.2.10, 3.2.11, 3.2.12 e 3.2.13) foram inoculadas com $0,05 \mathrm{ml}$ da suspensão de esporos (item 3.12.2), sendo esta espalhada, com alça de platina, em estrias. As placas foram incubadas a $28^{\circ} \mathrm{C}$ e após 7,14 e 21 dias de cultivo, realizadas leituras das cores do micélio aéreo, reverso e pigmento.

A micromorfologia foi observada ao microscópio ótico com aumento de $100 x \cdot e$ 400x (Microscópio ótico Carl Zeiss) e classificada de acordo com o grupo morfológico preconizado por PRIDHAM et alii (1958).

\subsubsection{Resistência a antibióticos}

Para este teste foi utilizado o meio $M E$ (item 3.2.1) em placas contendo concentrações variadas das diferentes soluções de antibióticos (item 3.3.16). A suspensão de esporos (item 3.12.2) foi diluída de modo a conter $10^{6}$ células/ml. e inoculada em duplicata na superfície da placa em 7 pontos, utilizando uma micropipeta de $5,0 \mu l$. 
3.12.6. Dẻterminação dos padrões eletroforéticos em gel de poliacrilamida (PACCOLA-MEIRELLES et alii, 1988)

As linhagens foram cultivadas como no item 3.6.2. sem acriflavina. A massa celular obtida foi lavada 3 vezes com água destilada em filtro de Buchner a vácuo, retirando-se parte da umidade com papel de filtro. 0 micélio foi triturado em banho de gelo e homogeneizado em tampão do gel empilhador gelado.(item 3.4.6) na proporção de $500 \mathrm{mg}$ de micélio para $1,0 \mathrm{ml}$ de tampão. Em seguida o homogeneizado foi centrifugado em centrífuga refrigerada durante 30 minutos a $18.000 \mathrm{rpm}$. O sobrenadante foi coletado, uma parte misturada ao tampão da amostra (item 3.4.8) na proporção de $1: 1$ para aplicação no gel de poliacrilamida e o restante foi conservado a $-20^{\circ} \mathrm{C}$.

\subsubsection{Preparo dos géis}

o sistema usado foi o de placas verticais de $15 \mathrm{~cm}$ de largura, $16 \mathrm{~cm}$ de altura e $0,8 \mathrm{~mm}$ de espessura. Inicialmente foi vertido o gel separador na placa (item 3.12.6.2); após a polimerização deste gel foi adicionado o gel empilhador (item $3 \cdot 12 \cdot 6 \cdot 3$ ). Antes deste gel sofrer polimerização, o pente fói introduzido com a finalidade de formar as canaletas onde posteriormente foram depositadas 
as amostras. Após cọmpleta e perfeita polimerização o pente foi retirado e as canaletas do gel lavadas com tampão eletrólito (item 3.4.7). A placa foi colocada na cuba de eletroforese vertical contendo o tampão eletrólito e a seguir as amostras foram aplicadas nas canaletas (50 $\mu l$ por canaleta). Com auxílio de uma pipeta Pasteur, as canaletas foram completadas com o tampão eletrólito.

A corrida foi conduzida a $4^{\circ} \mathrm{C}$, inicialmente a $100 \mathrm{~V}$ até a frente atingir o gel separador, em seguida a voltagem foi alterada para $150 \mathrm{~V}$ até o final da corrida.

$3.12 \cdot 6.2$. Gel separador a $10 \%$

- Tampão do gel separador (item 3.4.5) $3,0^{\prime} \mathrm{ml}$

- Solução de acrilamida (item 3.3.5) $10,0 \quad \mathrm{ml}$

- Persulfato de amônio 10\% $0,225 \mathrm{ml}$

- TEMED $16,80 \mathrm{ml}$

3.12.6.3. Gel empilhador a $4 \%$

- Tampão do gel empilhador (item 3.4.6)

$1,5 \mathrm{ml}$

- Solução de acrilamida (item 3.3.5) $2,0 \quad \mathrm{~m} 1$

- Agua desmineralizada $11,4 \mathrm{ml}$

- Persulfato de amônio 10\% $0,112 \mathrm{ml}$

- TEMED $0,015 \mathrm{ml}$ 


\section{$3: 12 \cdot 6.4$. Revelação das esterases}

Após a corrida, o gel foi cuidadosamente retirado da placa e colocado em cuba de plástico contendo $50 \mathrm{ml}$ de solução reveladora (item 3.3.6) onde permaneceu até as bandas aparecerem. Em seguida o gel foi lavado e fixado em solução aquosa de glicerol a $10 \%$.

3.12,6.5. Revelação de proteínas totais

Após a corrida, o gel foi retirado como no item 3.12 .6 .4 e colocado em cuba de plástico contendo $50 \mathrm{ml}$ do fixador PAGE (item 3.3.7) por uma noite à temperatura ambiente. Em seguida foi usado descorante várias vezes.

3.12.6.6. Plastificação do gel

O gel foi envolvido em papel celofane molhado e, com o auxílio de um bastidor de bordado, foi esticado ao máximo o papel que o continha. As bordas do papel foram coladas no bastidor e vários furos com agulhá foram feitos a fim de escoar a água e secar rapidamente o gel. Quando completamente seco foi retirado e arquivado. 


\subsection{Produção de antibiótico}

\section{$3 \cdot 13 \cdot 1$. Linhagens}

Setores segregantes: Sma, Smb, Smc, Smcd e

Smce.

\subsubsection{Inóculo}

Suspensões de esporos de cada linhagem foram preparadas como no item 3.5 .1 .

\subsubsection{Fermentação}

Os cultivos foram realizados em frascos de Erlenmeyer de $250 \mathrm{ml}$ contendo $50 \mathrm{ml}$ de meio MP (item 3.2.19) e inoculados em triplicatas com $1,0 \mathrm{ml}$ de suspensão de esporos (item 3.5.1) de cada linhagem.

A incubação foị realizada a $30^{\circ} \mathrm{C}$ sob agitação de 170-180 rpm (Shaker New Brunswick) por 96 horas. A cada 24 horas foi realizado ensaio antimicrobiano. como descrito no item 3.6 .4 .

$3 \cdot 13 \cdot 4$. Extração

o caldo fermentado foi extraído com acetato de etila o qual foi evaporado sob pressão reduzida. o 
extrato bruto de acetato de etila foi purificado através de cromatografia em coluna, empacotada com sílica gel e eluída por benzeno, clorofórmio e metanol.

3.13.5. Ensaio antimicrobiano do líquido fermentado

Os testes foram realizados como descrito no

item 3.6.4.

3.13.6. Determinação quantitativa no líquido fermentado - Unidade Waksman

O mosto fermentado com 96 horas de cultivo foi filtrado a vácuo em funil de Buchner para separação da massa celular. Em seguida o líquido foi diluído (1:10) em água destilada esterilizada e volumes de $1 \mathrm{ml}$ a $0,01 \mathrm{ml}$ adicionados a placas de Petri esterilizadas. A estas placas foram adicionados de $9,0 \mathrm{ml}$ até $9,99 \mathrm{ml}$ de meio Sabouraud (item 3.2 .6 ) fundido e resfriado a $45^{\circ} \mathrm{C}$. Após solidificação, foram realizadas estrias com uma suspensão de crescimento de Candida albicans IBB50 (item 3.5.3). A quantificação da unidade $(\mathrm{U} / \mathrm{ml})$ arbitrária de Waksman foi determinada pela inibição das estrias do microrganismo nas diferentes diluições do líquido fermentado. 


\section{RESULTADOS E DISCUSSAO}

4.1. Tratamento com agente intercalante

O tratamento das linhagens selvagens de $\underline{S}$ parvulus IA-M3042 e S. regensis IA-M3053 com acriflavina mostra que ambas respondem igualmente à mesma concentração do agente intercalante. 0 uso de 5,0 e $6,0 \mathrm{\mu g} / \mathrm{ml}$ de acriflavina (item 3.6 ) promoveu inibição de crescimento da ordem de 95 e $99 \%$, respectivamente. Contudo, para a linhagem selvagem de $S$. felleus IA-M3079, somente com 37,5 e $40,0 \mu \mathrm{g} / \mathrm{ml}$ foram alcançados aqueles níveis de inibição (Tabela 3).

Tabela 3

Ação das diferentes concentraçoes de acriflavina sobre o crescimento de três linhagens de Strentomyces

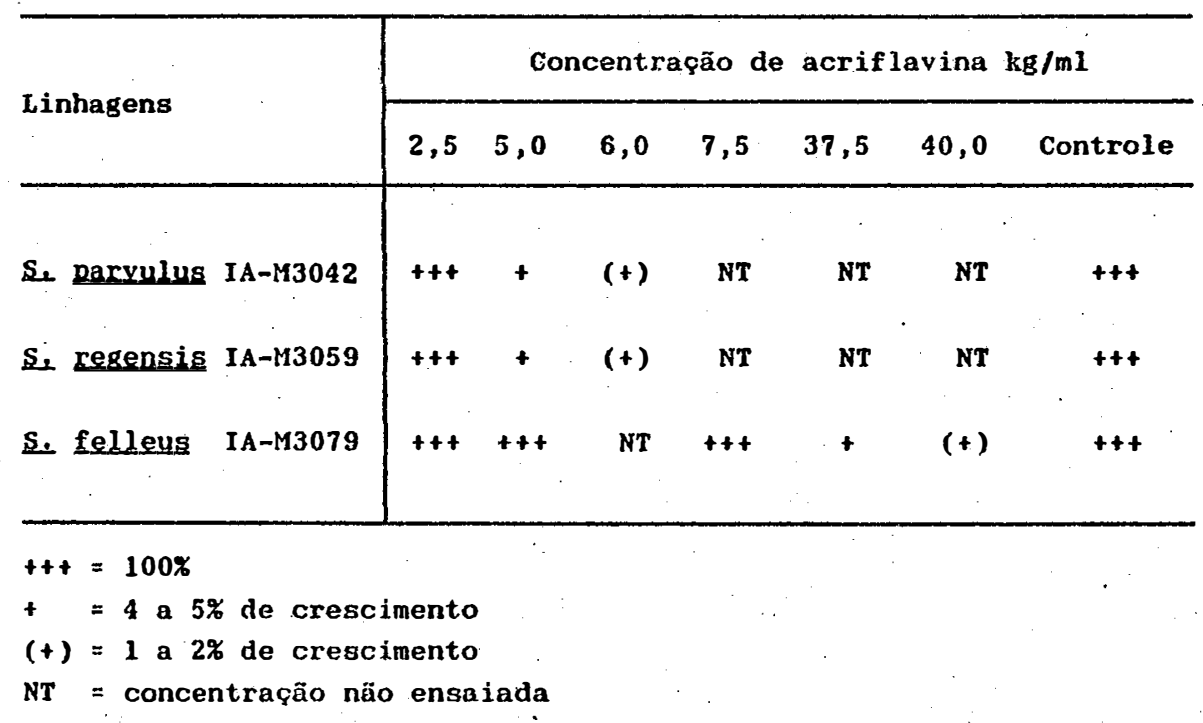


As colônias derivadas da massa celular obtida do tratamento por acriflavina apresentaram variantes sem o pigmento amarelo-laranja característico das Iinhagens selvagens produtoras de actinomicina e, além disso, não exibiram halo de inibicão para B. subtilis. IA-16.

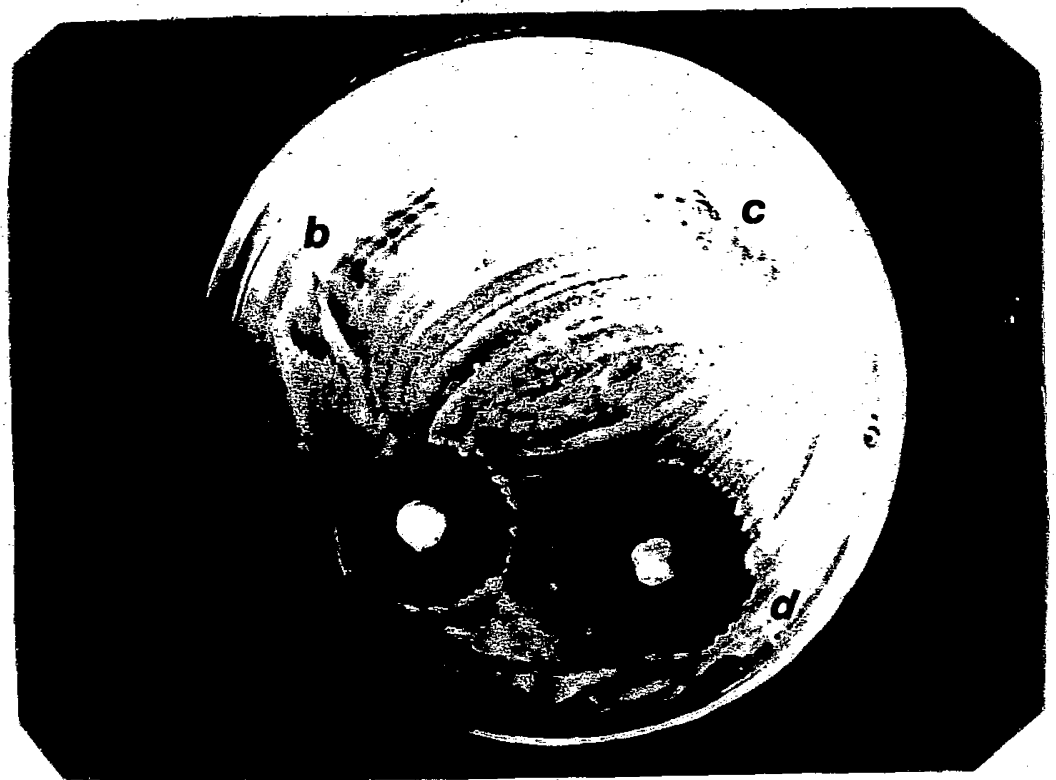

Figura 1. Halo de inibição para B. subtilis IA-16 da linhagem selvagem de S, felleus IA-M3079 e de suas variantes.
a) Streptomyces felleus. IA-M3079
b) $\mathrm{AF}-3079(90 / 57)$
c) $\mathrm{AF}-3079(84 / 50)$
d) $\mathrm{AF}-3079(196)$ 
A Tábela 4 mostra que entre as espécies ensaiadas, $S$ felleus IA-M3079 foi a mais instável quanto a produção de actinomicina, apresentando perda espontânea de $3,37 \%$ e, após o tratamento, $11,73 \%$ das progênies não produziam actinomicina $\left(\right.$ act $\left.{ }^{-}\right)$. Em $S$, regensis IA-M3053 e S parvulus IA-M3042, $5,26 \%$ e $6,52 \%$, respectivamente, das variantes eram act-, após o tratamento com acriflavina.

Tabela 4

Frequência percentual de ocorrência de progênies não produtoras de actinomicina nas diferentes espécies de Strentomyces, espontaneamente e por tratamento com acriflavina.

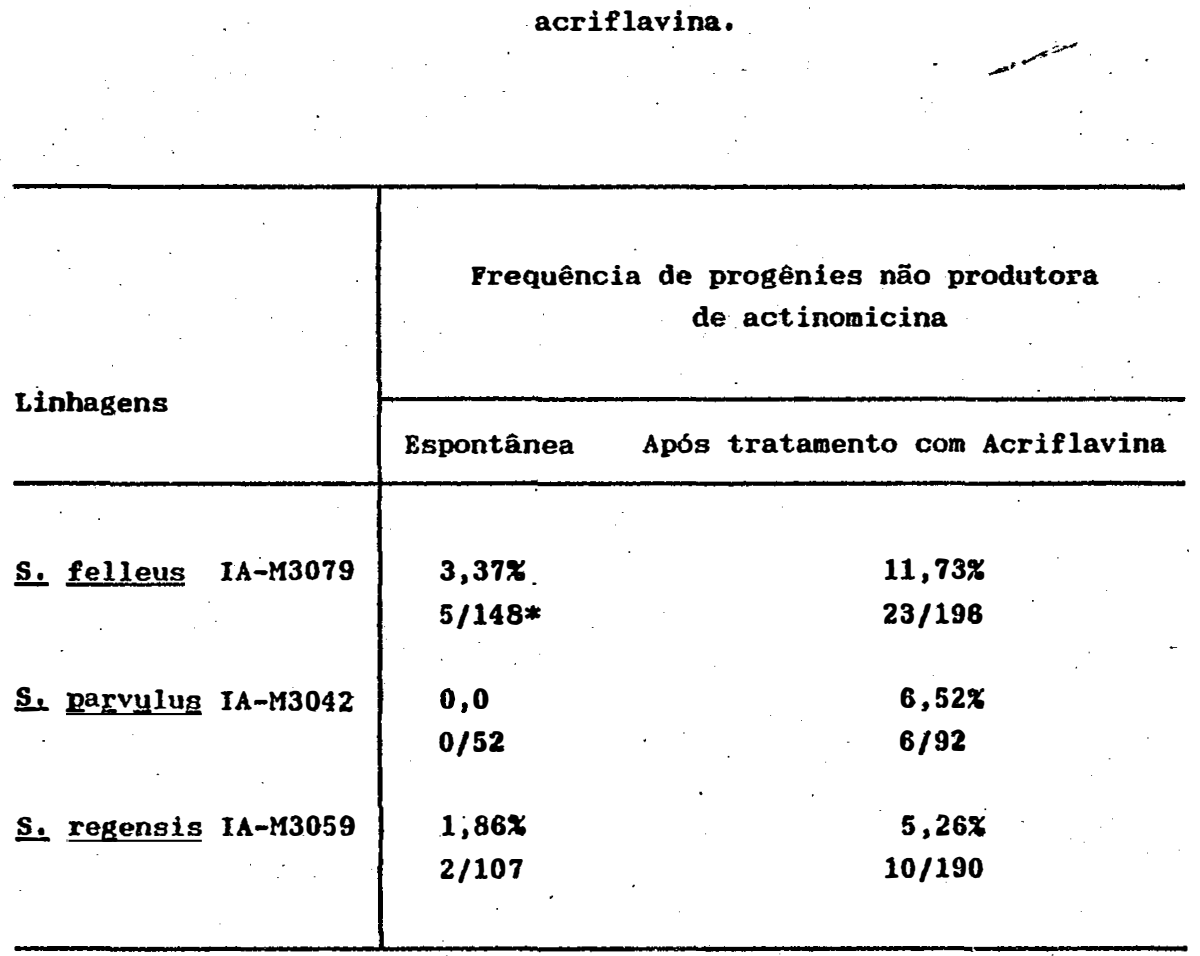


Esta menor frequência percentual de variantes act $^{-}$em $S_{\text {e regensis }}$ IA-M3053 e S. parvulus IAM3042 (Tabela 4), possivelmente está relacionada com o número de cópias de elementos extracromossômicos, como foi observado por CRAMERI et alii (1986). Estes autores, investigando a eficiência do brometo de etídio como agente eliminador de plasmídio, mostraram que $\underline{\text { s. Lividans piJ61 }}$ com baixo número de cópia, apresentou 100\% de eliminação deste elemento genético, não sendo observado o mesmo com $S_{\text {. }}$ Lividans piJ702 com elevado número de cópias de plasmídios.

Alterações nas características fenotípicas de estreptomicetos pelo uso de agentes intercalantes têm sido observadas em vários estudos. Em s. hygroscopjeuls 358 AV2 a concentração de $0,5 \mu \mathrm{g} / \mathrm{ml}$ de acriflavina promove um crescimento pobre, sendo observado na população que 5\% das colônias não produzem o antibiótico carriomicina, nem formam micélio (OGURA et alii, 1986). Ás observações de SHAW \& PIWOWARSKI (1977) com So bikiaiensis ATCC11062, produtor de estreptomicina, mostram que 7,76\% das colônias perderam a capacidade de produzir o antibiótico, enquanto 23\% deixaram de formar micélio aéreo. Nessas linhagens observa-se que a produção de antibióticos não está relacionada com a formação de micélio aéreo, enquanto nestes experimentos apenas em $S_{2}$ Darvulus IA-M3042 foi observado este efeito pleiotrópj.co. 
O tratamento realizado por OCHI \& KATZ (1978) em S. parvulus ATCC 12434 e Se antibioticus 3720 com. $5,0 \mathrm{\mu g} / \mathrm{ml}$ de acriflavina mostrou que $15,0 \%$ e $20,8 \%$, respectivamente, das colônias deixaram de produzir actinomicina, como também não foi observada qualquer relação entre a perda de micélio e a produção do antibiótico. A elevada frequência de colônias não produtoras de actinomicina decorre, possivelmente, das condições de tratamento utilizadas por aqueles autores, os quäis submeteram a massa micelial obtida do tratamento com acriflavina a formação e regeneração de protoplastos. Segundo HOPWOOD et alii (1983), AGUILLAR \& HOPWOOD (1982) formação e regeneração de protoplastos tem sido atribúída a eliminação de elementos extracromossômicos " e alterações fenotípicas.

4.1.1. Características fenotípicas das variantes obtidas após tratamento por acriflavina

As variantes obtidas neste trabalho após tratamento com acriflavina mostram características peculiares quanto à formação do pigmento amarelo e produção do act inomicina.

A análise da Tabela 5 mostra que a perda de miçljo aéreo e pigmento amarelo foi observada apenas em $S_{\text {. }}$ 
paryulus IA-M3042, concordando com os resultados de OCHI e KATZ (1978) para s, parvulus ATCC 12432.

Tabela 5

Caracteristicas fenotipicas das linhagens selvagens e das variantes não produtoras de actinomicina obtidas após o tratamento com acriflavina

\begin{tabular}{|c|c|c|c|c|c|}
\hline & Frequência & Micélio & aéreo* & Pigmento & solúvel \\
\hline . & tes act ${ }^{-}$ & Formação & cor & Rormação & cor \\
\hline S. parvulus & & & cinza & & amarelo \\
\hline$I A-113042$ & & Presente & & Presente & laranja \\
\hline Variantes & $6,52 \%$ & Ausente & & Ausente & \\
\hline s, felleus & & & cinza & & amarelo \\
\hline IA-M3079 & & Presente & anarelado & Presente & laranja \\
\hline Variantes & $11,73 \%$ & Presente & branco & Ausente & \\
\hline S. regensis & & & cinza & & amarelo \\
\hline IA-M3059 & & Presente & escuro & Presente & laranja \\
\hline Variantes & $5,26 \%$ & & & & . \\
\hline $134(8)$ & - & Presente & $\begin{array}{l}\text { cinza } \\
\text { escuro }\end{array}$ & Presente & $\begin{array}{l}\text { marron } \\
\text { escuro }\end{array}$ \\
\hline $105(4)$ & & Presente & $\begin{array}{c}\text { amarelo } \\
\text { claro }\end{array}$ & Ausente & \\
\hline $53(5)$ & & Presente & $\begin{array}{l}\text { cinza } \\
\text { claro }\end{array}$ & Presente & $\begin{array}{l}\text { marron } \\
\text { escuro }\end{array}$ \\
\hline
\end{tabular}

* Caracteristicas fenotxpicas observadas em meio de esporulaçäo (MB) (item 3.2.1)

act $\hat{t}^{-}=$variantes näo produtoras de actinomicina. 
Em S. regensis IA-M3053 as variantes act ${ }^{-}$ mostraram diferentes cores para o micélio aéreo e perderam o pigmento amarelo-laranja, mas apresentaram formação de pigmento marrom-escuro (possivelmente pigmento melanínico) que não foi afetado pelo agente intercalante (Figura 2), fato igualmente observado em S. bikiniensis ATCC 11062 por SHAW \& PIWOWARSKI (1977). A linhagem selvagem de s. regensis IA-M3053 se caracteriza como melanina positiva, contudo as variantes de $S$, felleus IA-M3079 não produtoras de actinomicina (act-) mostraram um único tipo morfológico - micélio aéreo branco - bem desenvolvido, sem formação de pigmento solúvel. 

a
b
C
d

Figura 2. Características morfológicas das variantes de $\underline{S}$ regensis IA-M3053 não produtoras de actinomicina obtidas após o tratamento com acriflavina:
a) $\mathrm{AF}-3053(141 / 2)$
b) $\mathrm{AF}-3053 \quad(105 / 4$
c) $\mathrm{AF}-3053(53 / 5)$
d) $\mathrm{AF}-3053(134 / 8)$

A Tabela 6 mostra que entre as variantes de S. Lelleus IA-M3079 obtidas após o tratamento com acriflavina, $8,67 \%$ apresentaram ausência de micélio aéreo e pigmontaciăo variável. Entre as variantes com formação de pig- 
mento amarelo solúvel $(79,59 \%$ do total) $1,02 \%$ apresentaram micélio aéreo amarelo pálido e pigmento solúvel amarelo escuro estável $\left(\mathrm{Act}^{++}\right)$. Em $\mathrm{S}$, regensis IA-M3053 8,94\% das variantes sem micélio aéreo apresentaram pigmento amarelo estável e entre estas variantes, 3,68\% apresentaram maior produção de actinomicina (halo de inibição para Bs subtilis IA-16 de aproximadamente $27,3 \mathrm{~mm})$.

A variação e a estabilidade de pigmento e de micélio aéreo apresentadas pelas amostras act ${ }^{-}$(AF-3079 $(84 / 50)$ e $\mathrm{AF}-3079(90 / 57)$ e act $^{++} \cdot(\mathrm{AF}-3079(128 / 32$ e $\mathrm{AF}-3079$ $(99 / 3)$ estão expressas na figura 3 . Foi observada mudança na morfologia da colônia e na pigmentação das variantes AF$3079(196)$ e AF-3079(96/63), sendo acompanhada pela perda de resistência a actinomicina. o aumento na instabilidade fenotípica por agentes intercalantes foi inicialmente observado em $S$, venezuelae e $S$, alboniger por AKAGAWA et alii (1979) e REDSHAW et alii (1979). Investigações mais recentes sugerem que a instabilidade decorre da presença de genes instáveis no cromossoma de linhagens selvagens, enquanto que a análise de variantes fenotípicas mostra . deleções de regiões cromossomais contendo os genes instáveis (USDIN et alii, 1985; SCHREMPF, 1983). 
Tabela 6

Frequêricia percentual das caracteristicas fenotipicas apresentadas pelas variantes de S. felleus IA-M3079 e S, regensig IA-M3053, obtidas por tratamento com acriflavina

\begin{tabular}{|c|c|c|c|c|c|c|c|c|c|}
\hline \multirow{2}{*}{ Variantes } & \multicolumn{2}{|c|}{ Micélio aéreo } & \multicolumn{3}{|c|}{ Pigmento solúvel } & \multicolumn{4}{|c|}{ Actinomicina } \\
\hline & Presente & Ausente & Presente & Variável & Ausente & Act- & Actv & Actt & Actt+ \\
\hline S. felleus & $91,32 \%$ & $8,67 x$ & $79,59 \%$ & $8,67 \%$ & $11,73 \%$ & $11,73 \%$ & $8,67 \%$ & $78,57 \%$ & $1,02 \%$ \\
\hline IA-M3079 & $179 / 196 *$ & $17 / 196$ & $156 / 196$ & $17 / 196$ & $23 / 196$ & $23 / 196$ & $17 / 196$ & $154 / 196$ & $2 / 196$ \\
\hline s. regensis & $91,05 \%$ & $8,94 \%$ & $94,7 x$ & - & $5,26 \%$ & $5,26 x$ & - & $91,05 \%$ & $3,68 \%$ \\
\hline IA-M3053 & $173 / 190$ & $17 / 190$ & $180 / 130$ & -- & $10 / 190$ & $10 / 190$ & -- & $173 / 190$ & $7 / 190$ \\
\hline
\end{tabular}

Act- = ausência de halo de inibição;

Actt = halo de inibição igual ao da selvagem $(26,68 \mathrm{~mm}$ para S. fellęug e 25,5m para se regensis IA-M3053;

Acttt = halo de inibiçâo maior que o da selvagem $(29,40 \mathrm{~mm}$ para sc. felleug IA-M3079 e 27,3mm para se regensig IA-M3053;

Actv = halo de inibição de inibição variável;

* Número de colônias variantes/número de colônias ensaiadas. 


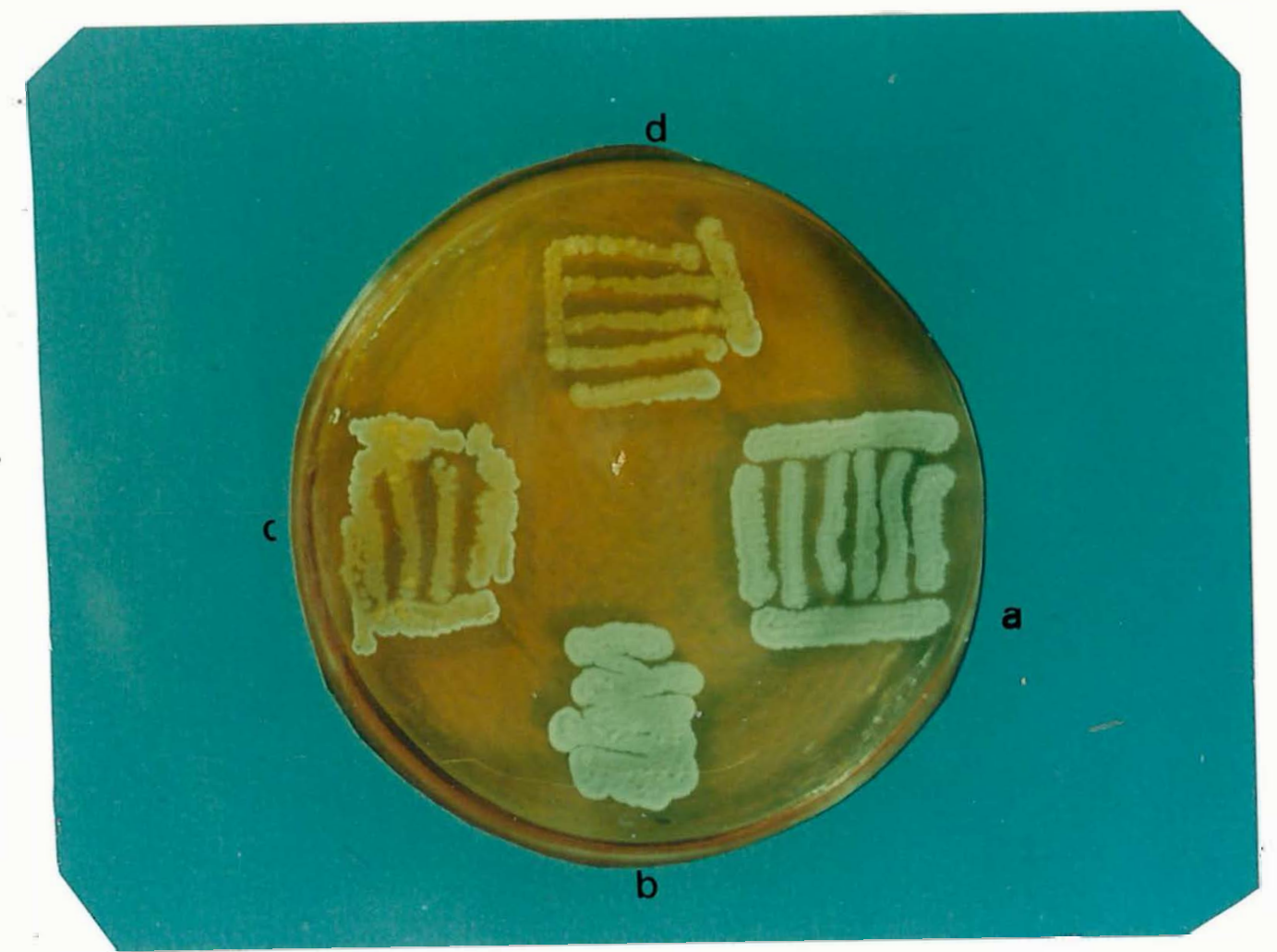

Figura 3. Características fenotípicas (produção de pigmento e micélio aéreo) das variantes de $S$. felleus IA-M3079 obtidas após o tratamento por acriflavina.
a) $\mathrm{AF}-3079(84 / 50) \quad\left(\mathrm{Act}^{-}\right)$
b) $\mathrm{AF}-3079(90 / 57) \quad\left(\mathrm{Act}^{-}\right)$
c) $\mathrm{AF}-3079(128 / 32)\left(\mathrm{Act}^{++}\right)$
d) $\operatorname{AF}-3079(99 / 3) \quad\left(\right.$ Act $\left.^{++}\right)$ 
Os três tipos morfológicos como visto na

Tabela 6 (act $t^{-}$act $v$ e act $\left.{ }^{++}\right)$apresentaram características fenotípicas marcantes (Tabela 7 ).

Tabela 7

Caracteristicas morfológicas e fisiológicas observadas entre

as variantes de $S_{\text {f }}$ felleus IA-M3079 obtidas após o

tratamento com acrivlafina

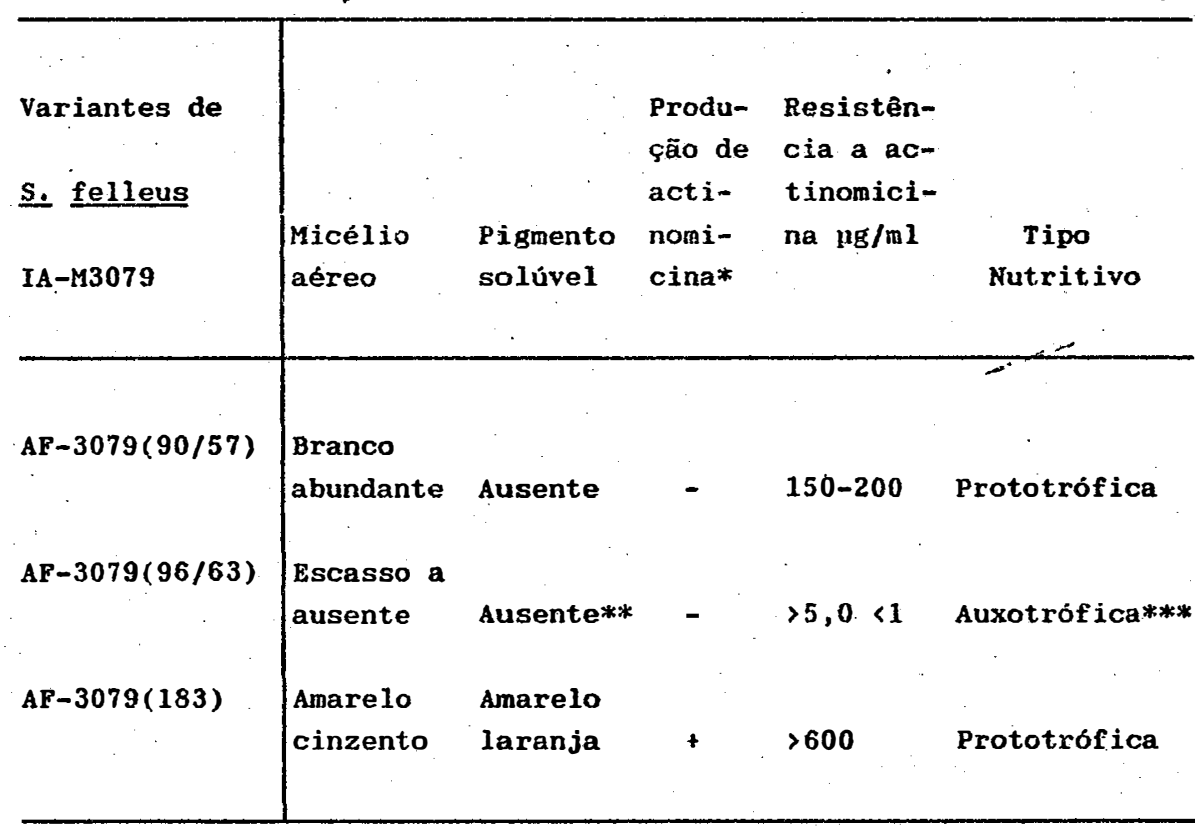

* + = produção positiva

- = ausência de produção

** = o pigmento foi perdido foi perdido após repicagens sucessivas

*** = Auxotrofia para aminoácido 
A variante AF-3079(90/57) se apresentou estável em todas as características morfológicas e fisiológicas, mostrando resistência intermediária a actinomicina $(150-200 \mathrm{\mu g} / \mathrm{ml})$. A variante AF-3079(96/63) formou pigmento amarelo-laranja intenso variável e, após algumas transferências, tornou-se apigmentada, não produzindo actinomicina e apresentando elevada sensibilidade a este antibiótico $(>5<15 \mu \mathrm{g} / \mathrm{ml})$. Esta mutante morfológica apresenta efeito pleiotrópico para a produção de actinómicina e igualmente como em s. colelicolor A3(2), mutantes bald ou Amy ${ }^{-}$não produzem actinorrodina (MERRICK, 1976). O termo bald ou $\mathrm{Amy}^{-}$é usado para mutantes bloqueadas na formação de micélio aéreo. Várias investigações mostram uma estreita correlação entre diferenciação - especialmente esporulação - e produção de antibióticos. Tem sido sugerido que a perda destas características fenotípicas após tratamento com agente intercalante se deva, ou à presença de plasmídios (OKANISHI, 1979; REDSHAW et alii, 1979) ou, como foi sugerido para a perda da formação de melanina em $\underline{S}$ : reticuli, rearranjo cromossomal ocasionado por amplificação de DNA (SCHREMPF, 1983; CULLUM et alii, 1986). A variante AF-3079(183) mostrou formação de pigmento amarelo intenso e alta resistência a actinomicina. 
Neste trabalho a instabilidade genética observada em S. felleus IA-M3079 após o tratamento com acriflavina pode estar associada a qualquer um destes aspectos, entretanto uma conclusão só será possível após novas investigações genéticas e moleculares. As variantes $\mathrm{AF}-3079(90 / 57)$ e $\mathrm{AF}-3079(96 / 63)$ serão de grande importância na investigação da sequência metabólica para biossíntese de actinomicina em s. felleus IA-M3079 através da determinação da ocorrência das enzimas kinurenina formamidase "e fenorizanona sintetase. Estas são enzimas chaves da via biossintética de actinomicina em s. antibioticus (KATZ, 1967; KATZ \& WEISSBACH, 1963).

o estudo comparativo das característicás fenotípicas da variante AF-3079(183) com o seú parental $S_{\text {. }}$ felleus IA-M3079 pode ser observado nas tabelas 8 e 9 . A Tabela 8 mostra que a variante AF-3079(183) apresenta elevada estabilidade para a produção de actinomicina (98\%). O halo de inibição para B. subtilis IA-16 está em torno de $29 \mathrm{~mm}$ e $23,63 \%$ das colônias da linhagem selvagem mostram halo de inibição similar (Tabela 9 ). 


\section{Tabela 8}

Estudo comparativo das caracteristicas fenotipicas de vários clones da linhagem parental S, felleus IA-M3079 e da variante $A F-3079(183)$

\begin{tabular}{|c|c|c|c|c|c|c|c|c|}
\hline \multirow{2}{*}{ Linhagens } & \multicolumn{3}{|c|}{ Pigmento amarelo } & \multicolumn{2}{|l|}{ Micélio } & \multicolumn{3}{|c|}{ Prod. de actinomicina } \\
\hline & Intenso & Ausente & Claro & Presente & Ausente & $\operatorname{Act}^{++}$ & Act $^{+}$ & Act ${ }^{-}$ \\
\hline S. fe1 leus & $23,63 \%$ & $3,64 \%$ & $72,73 \%$ & $92,7 \%$ & $7,27 \%$ & $23,63 \%$ & $72,73 \%$ & $3,64 \%$ \\
\hline$I A-M 3079$ & $13 / 5.5 *$ & $2 / 55$ & $40 / 55$ & $51 / 55$ & $4 / 55$ & $13 / 55$ & $40 / 55$ & $2 / 55$ \\
\hline \multirow[t]{2}{*}{$A F-3079(183)$} & $98 \%$ & $2,0 \%$ & 0,0 & $100 \%$ & 0,0 & $98 \%$ & 0,0 & $2,0 \%$ \\
\hline & $49 / 50$ & 1,50 & $00 / 50$ & $50 / 50$ & $00 / 50$ & $49 / 50$ & $00 / 50$ & $1 / 50$ \\
\hline
\end{tabular}

Act $^{++}=$halo médio $29,40 \mathrm{~mm}$

Act $^{i}=$ halo médio $26,68 \mathrm{~mm}$

Act $^{-}=$sem halo de inibição

* = número de colônias variantes/número de colônias ensaiadas 
Tabela 9

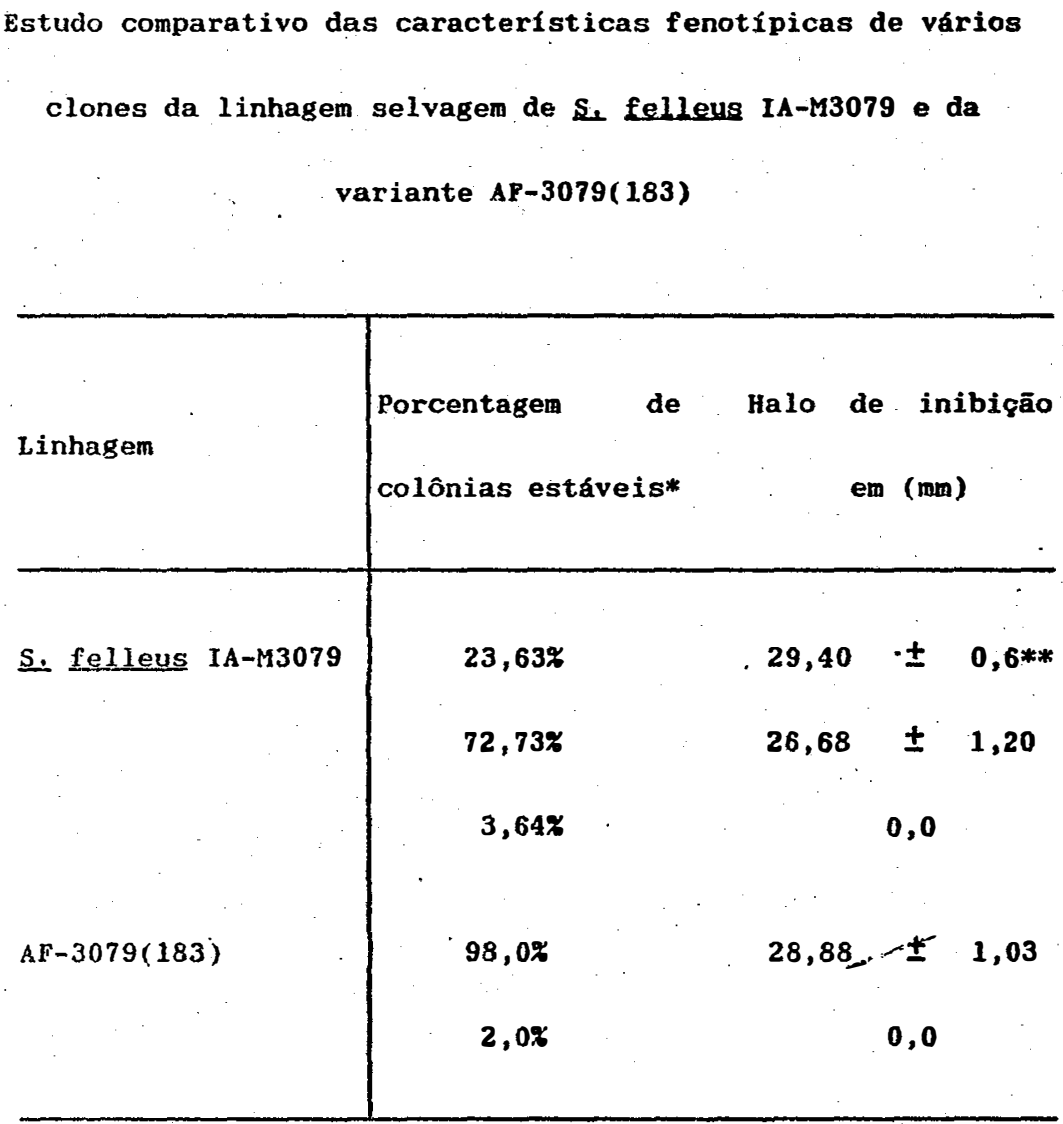

* Média de 55 colónias ensaiadas para B. subtilís IA-16

** Desvio padrão

A variação das características fenotípicas na linhagem selvagem foi maior que aquela observada na variante AF-3079(183). Similarmente, RAMOS et alii (1986) trataram $S_{2}$ rimosus QBS produtor de oxitetraciclina com 80 $[n / m]$ de acriflavina e observaram variantes alteradas em suia morfologia, que apresentavam alta produção de 
oxitetracicilina associada com aumento na intensidade de pigmento solúvel, não sendo isoladas variantes não produtoras. Estas observações permitiram àqueles autores sugerirem que os genes responsáveis pela regulação da produção de oxitetraciclina foram afetados e não os genes estruturais. Entretanto, a ação de diferentes agentes intercalantes, observada por OCHI \& KATZ (1978) em S. parvulus ATCC 12432 e S, antibioticus 3720 Rutgers, mostra variantes não produtoras de actinomicina, sugerindo a possibilidade de alterações em genes estruturais.

A ação de corantes intercalantes ainda é especulativa. A literatura cita inúmeros trabalhos mostrando a eficiência de agentes eliminadores de plasmídios, enquanto outros (HOPWOOD \& CHATER, 1984; CHATER \& HOPWOOD, 1983) sugerem que mais do que um eliminador de plasmídio, estes agentes podem causar frequentemente rearranjo cromossomal ou extracromossomal.

4.2. Caracterização física de DNA plasmidial em Streptemyces felleus IA-M3079

Através do método modificado de KADO \& LIU (1981) indicado no item 3.7.4. foi possível visualizar uma banda eletroforética em S. felleus IA-M3079 que podia ser confundida com DNA cromossomal. Entretanto, extrações das 
variantes não produtoras de actinomicina obtidas espontaneamente $(E-3079(53 c))$ e também após tratamento com acriflavina (AF-3079(90/57)) não mostraram qualquer banda eletroforética. Foi observada banda eletroforética correspondente ao plasmídio piJ702 (5,6 kb) com elevado número de cópias, enquanto que o plasmídio piJ943 $(20,6 \mathrm{~kb})$ com baixo número de cópias não foi detectado (Figura 5).

Estes resultados sugerem que o método pode ser inadequado para plasmídio de baixo número de cópias e/ou para elementos de alto peso molecular.

As investigações da literatura mostram que o

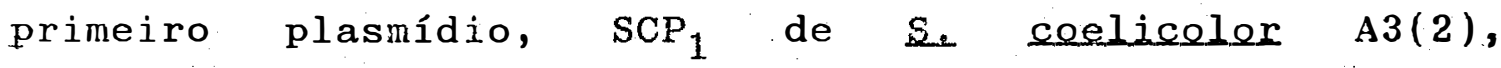
determinado geneticamente por VIVIAN (1971) e responsável pela resistência e produção de metilenomicina foi durante muito tempo refratário ao isolamento físico. Entretanto, só recentemente, KINASHI et alii (1987) isolaram de $\underline{\text { s. }}$ coelicolor A3(2) um elemento linear de $340 \mathrm{~kb}$, através da eletroforese ortogonal (OFAGE), visto como $\mathrm{SCP}_{1}$.

Outros plasmídios como $\mathrm{SLP}_{2}, \mathrm{SLP}_{3}$ e $\mathrm{SLP}_{4}$ de S. Lividans $66, \mathrm{SRP}_{1}$ e $\mathrm{SRP}_{2}$ de $\mathrm{S}$ r rimosus são refratários ao isolamento físico (HOPWOOD et alii, 1983; FRIEND et ałii, 1978 e RHODES et alii, 1984).

Um paralelo entre os dados da literatura e os obtidos neste trabalho sugere que o determinante genético de s. Selleus IA-M3079 faça parte deste elenco de 
plasmídios dificeis de serem isolados, possivelmente pelo baixo número de cópias ou, ainda, por ser de alto peso molecular.

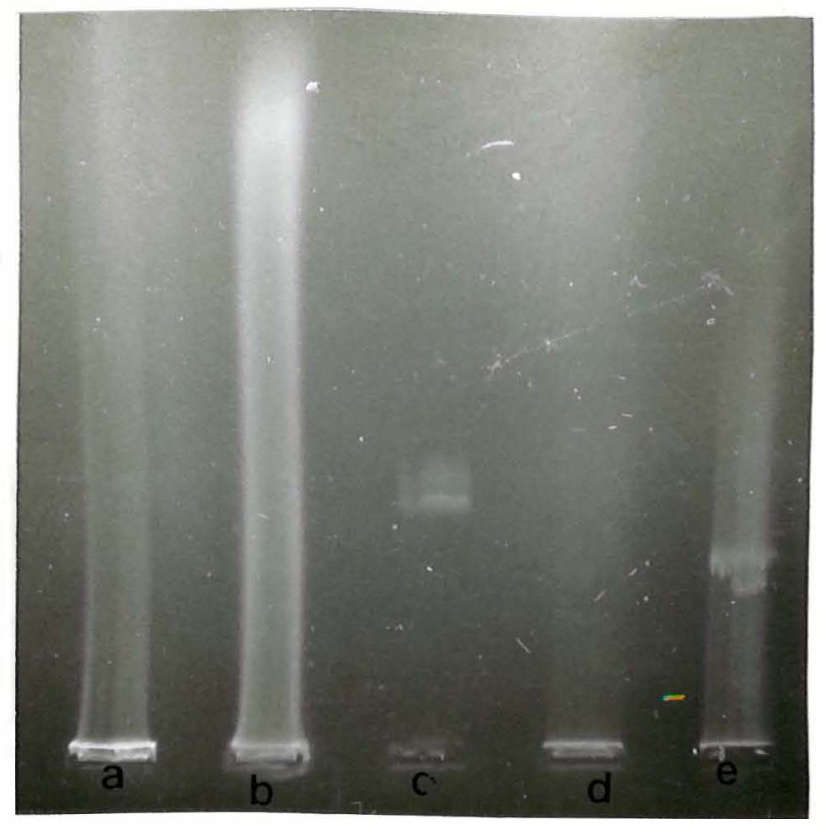

Figura 4. Eletroforese de DNA plasmidial obtido pelo método de KADO \& LIU (1981) modificado
a) IA-M3079
b) piJ 943
c) piJ702
d) $E-3079(53 c)$
e) $\mathrm{AF}-3079(90 / 57)$

Neste trabalho, nas três linhagens em estudo, foram observadas variantes não produtoras de 
actinomicina, o que sugere a possibilidade do envolvimento de elementos extracromossômicos. Contudo, estudos genéticomoleculares poderão posteriormente trazer maiores esclarecimentos, uma vez que corantes intercalantes podem causar mutação.

4.3. Caracterizą̧ão do fenótipo "pock" após cruzamento com S. Lividans TK24

Em decorrência da elevada instabilidade observada na formação de pigmento amarelo-laranja ligada à produção de actinomicina e pela não caracterização física de elementos extracromossômicos em S. felleuş IA-M3079, foi investigada a presença de plasmídio conjugativo através da formação de zigose letal também designada de fenótipo "pock".

Os cruzamentos com a linhagem testadora $\left(S_{2}\right.$ lividans TK24) e a visualização do fenótipo "pock" foram realizados como descrito no item 3.8 .

o plasmídio conjugativo piJ303 utilizado como controle positivo mostra a reação zigose letal (indicada por flexa) como zonas claras de inibição designada $\mathrm{Ltz}^{+}$por KIESER et alii (1982) (Figura 5). 


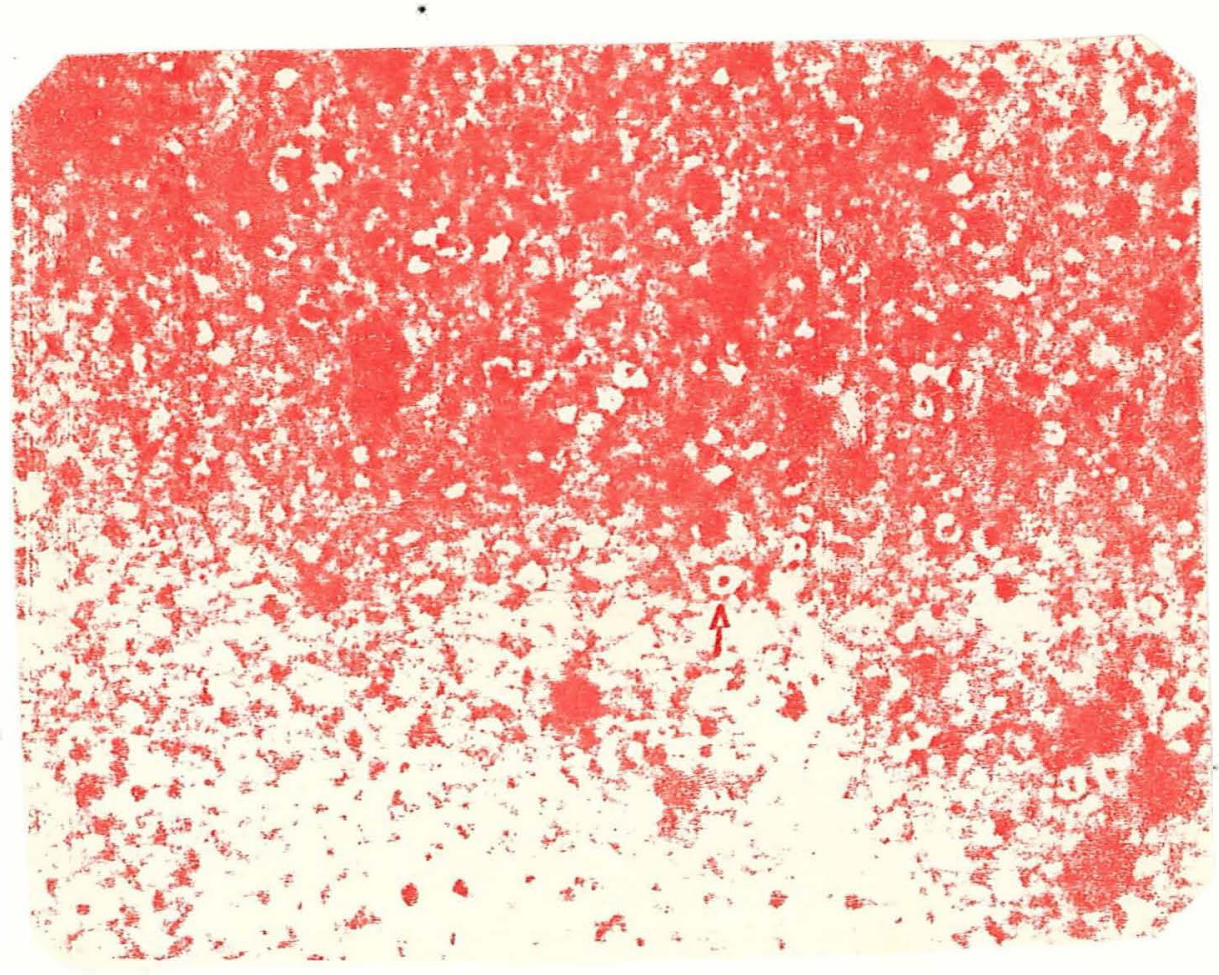

Figura 5. Fenótipo "pock" produzido pelo plasmídio pij303 em um "background" de S. Lividans TK24 livre de plasmídio (aumento $40 \mathrm{x}$ ).

Em S. felleus IA-M3079 foram observados diferentes tipos de zigose letal (Figura 7). O tipo A com grande zona clara de inibição se apresenta diferente da reação $\mathrm{Ltz}^{+}$de piJ303, porém similar ao fenótipo dos plasmídios pSCy3 e pSCy5 de S, noursei B3 (KOJIMA et alii, 1985), enquanto o tipo B mostra zona de inibição pequena, turva ou opaca, se assemelhando reação Ltz +/- do plasmídio 
variante piJ224 (KIESER et alii, 1982) e o fenótipo do plasmídio pSCy6 de S, noursei P251 (KOJIMA et alii, 1985).

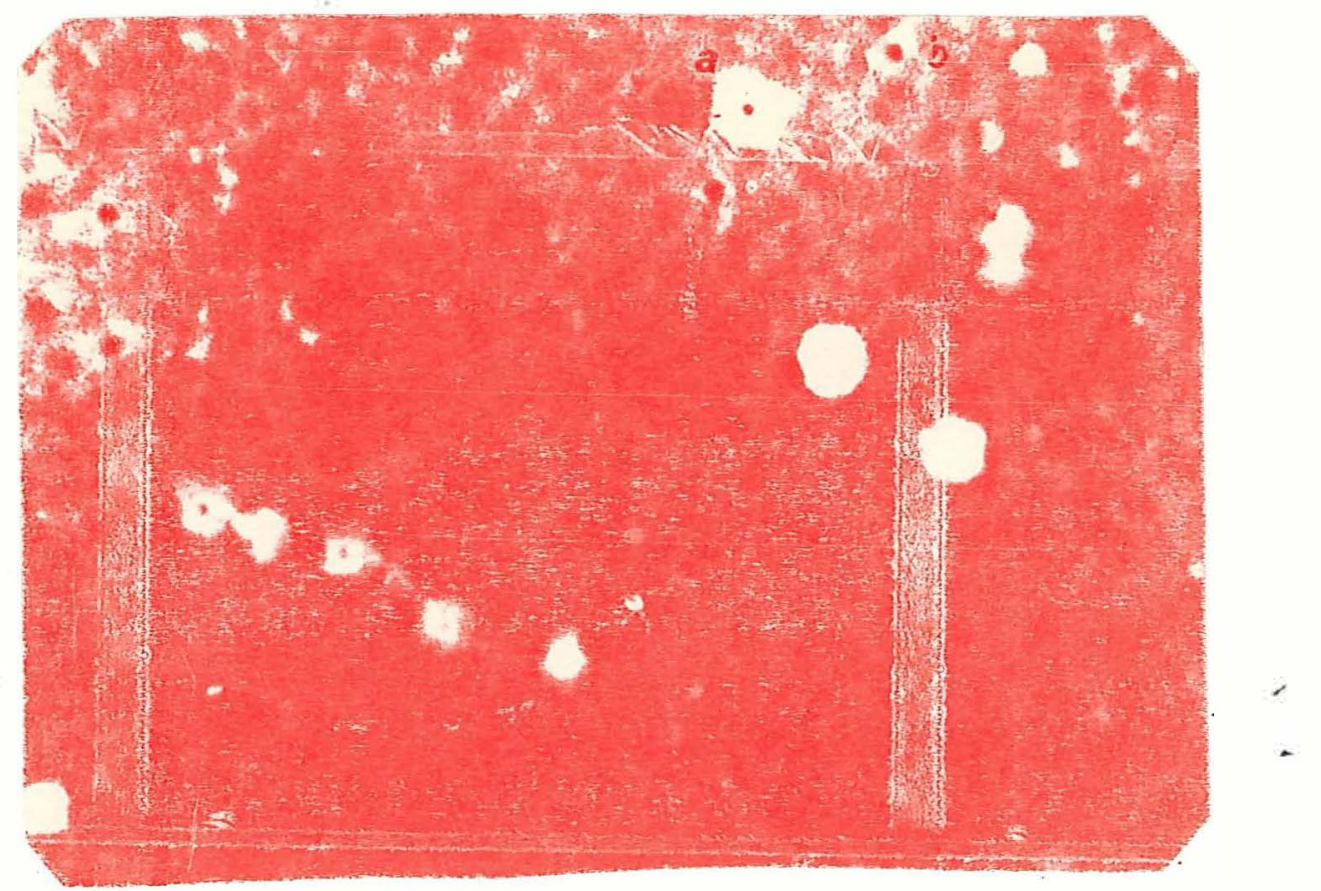

Figura 6. Fenótipo "pock" produzido pelo plasmídio de $S$. felleus IA-M3079 em um "background" de $S$. Lividans TK24 livre de plasmídio (aumento 15x).

SHINDOH et alii (1984) observaram em $\underline{\text { S. }}$ roseochromogenes S264 por transformação e formação do fenótipo "pock" a presença de dois plasmídios pSCR1a e pSCRb com pesos moleculares diferentes. Em S. Lividans 66 (HOPWOOD et alii, 1383 ) os plasmídios $\mathrm{SLP}_{2}$ e $\mathrm{SLP}_{4}$; em $S$. rimosus Pfizer SRP1 (FRIEND et alii, 1978) e SRP $_{2}$ (RHODES 
et alii, 1984) em $S_{\text {, erythreus }}$ SEP $_{1}$ (DE WITT, 1985) são detectáveis somente através do fenótipo "pock". Estas investigações demonstram que a ocorrência do fenótipo "pock" tem facilitado a determinação de mais de um plasmídio em Streptomyces através de diferentès tipos morfológicos de "pock". KIESER et alii (1982), procurando determinar a provável região que determina o fenótipo $\iota t z+$ em pis101, observaram "in vitro" que variantes desse plasmídio com fenótipo reduzido, Ltz +/- estavam associadas a uma série de inserções de uma região específica de piJ101. Segundo estes autores esta região é responsável pela função de espalhamento intramicelial envolvendo a migração de cópias de plasmídios e não a transferência intermicelial.

As linhagens de $S_{\text {. parvulus }} \mathrm{IA}-\mathrm{M} 3042$ e $\mathrm{S}_{\mathrm{o}}$ regensis IA-M3053 que apresentaram instabilidade fenotípica após o tratamento com acriflavina foram ensaiadas quanto à presença do fenótipo "pock" (Figuras 8 e 9). Em S. paryulus IA-M3042 foi observado fenótipo "pock" similar ao tipo de piJ303, enquanto que em $\underline{S}$, regensis IA-M3053 as colônias "pock" mostram características .intermediárias de zigose letal. (Ltz $+/-)$. Estas linhagens posteriormente serão investigadas em maior detalhe.

Houve uma tentativa de isolar e purificar a colônia "pock" tipo A de Se felleus TA-M3079, visando 
caracterizar fisicamente o determinante extracromossômico, sem êxito, entretañto.

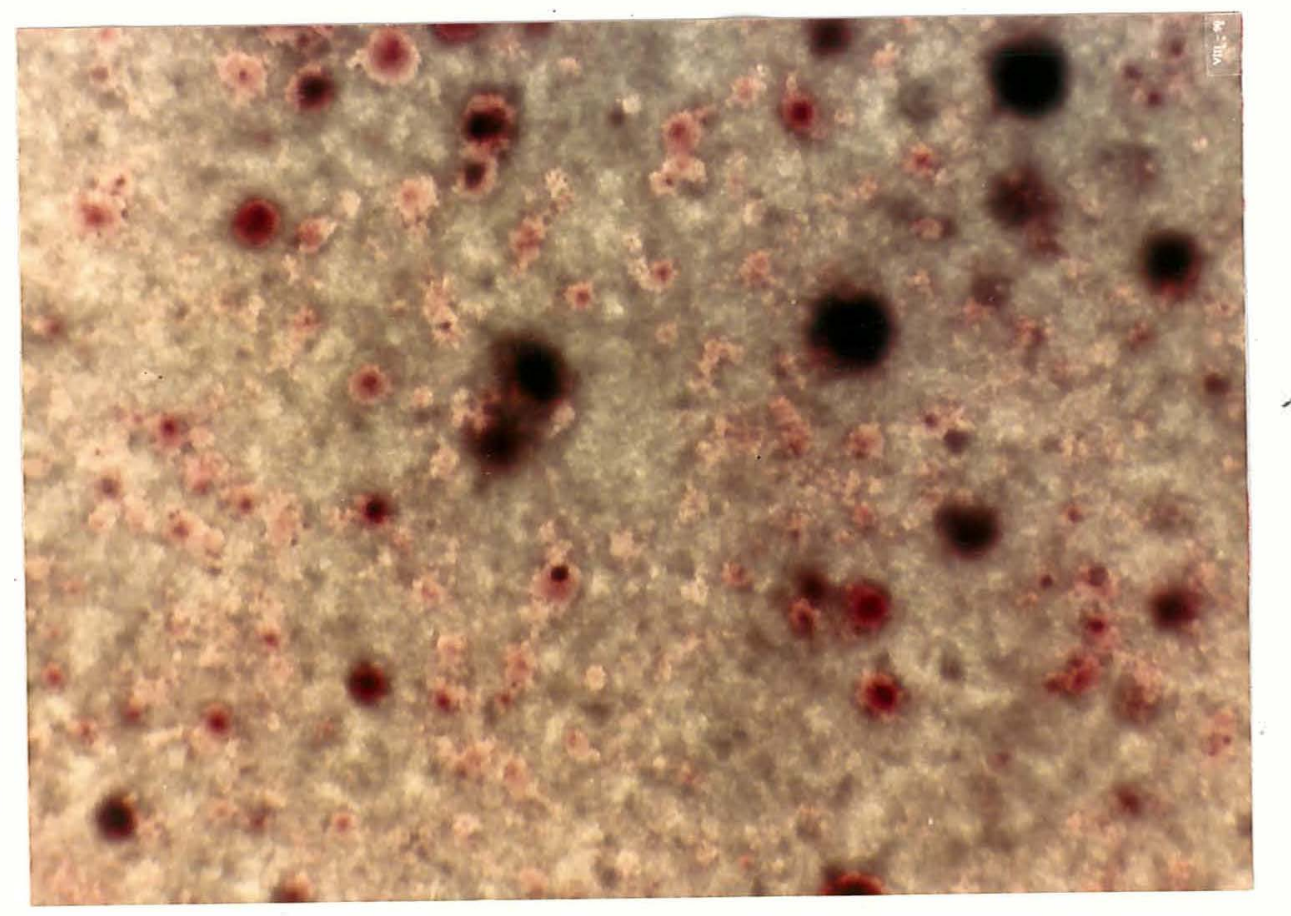

Figura 7. Fenótipo "pock" produzido pelo plasmídio de $\boldsymbol{S}_{\text {. }}$ regensis IA-M3053 sobre um "background" de $S_{\text {A }}$ lividans TK24 livre de plasmídio (aumento 15x). 


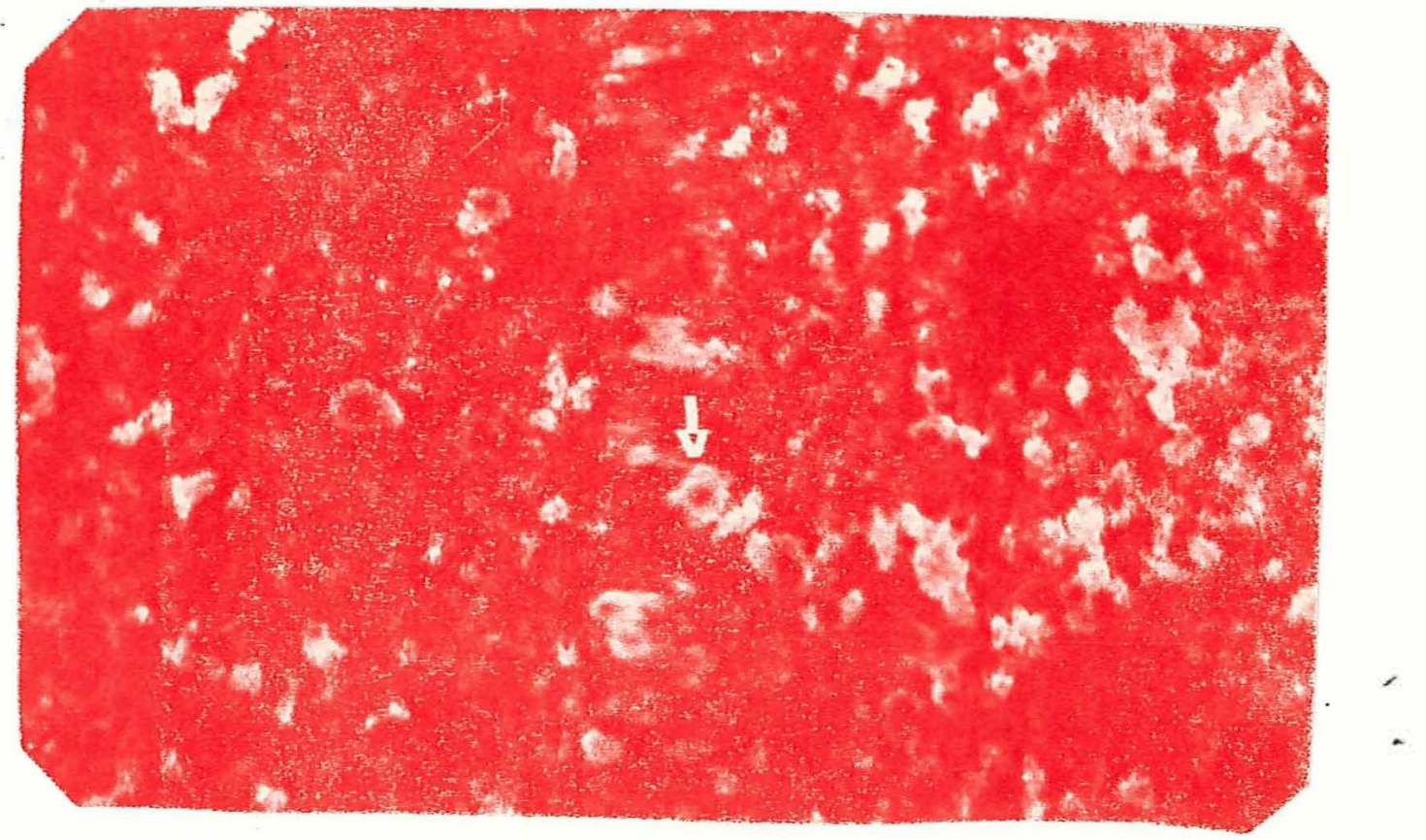

Figura 8. Fenótipo "pock" produzido pelo plasmídio de $\boldsymbol{S}_{\text {}}$ parvulus IA-M3042 sobre um "background" de $\underline{S}_{\text {}}$ Lividans TK24 livre de plasmídio (aumento $25 \mathrm{x}$ ). 
Neste trabalho, a formação de dois tipos de

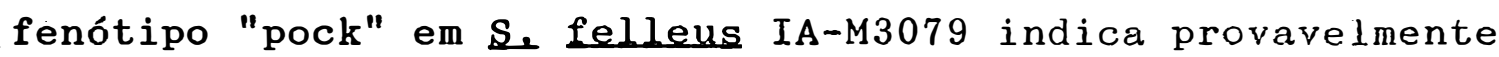
a presença de dois elementos extracromossômicos que poderão estar relacionados com a instabilidade fenotípica dessa linhagem, enquanto que $S$, parvulus IA-M3042 e s. regensis. IA-M3053 apresentam um único tipo de fenótipo.

Os cruzamentos entre $\mathrm{AF}-3079(90 / 57)$, E3079 (53at) e S. Lividans TK24 não mostraram fenótipo "pock", sugerindo que a perda da produção de actinomicina possa estar relacionada a este fator sexual. Entretanto, conclusão definitiva somente após análise genética detalhada entre linhagens geneticamente marcadas para verificar a localização de genes biossintéticos. Investigações realizadas por HAESE \& KELLER (1988) determinaram que genes para produção de actinomicina em $\underline{S}_{2}$ chrysomallus estão no cromossoma, enquanto OCHI (1982) sugere o envolvimento de plasmídios na produção de actinomicina em S. parvulus. ATCC 12434 .

A observação do fenótipo "pock" pode não significar presença de plasmídio autônomo nas linhagens em estudo, uma vez que plasmídios podem se originar pela formą̧ão de alças a partir de sequências cromossomais da linhagem testadora, como observado para os plasmídios piJ110 de s. parvulus e piJ408 de S. Llaucescens após cruzamento com Se lividans (HOPWOOD et alii, 1984). 
4.4. Fusão de protoplastos

Pelos estudos realizados neste trabalho, foi verificado que a formação de pigmento amarelo e a produção de actinomicina nas linhagens em estudo são características fenotípicas instáveis que, após tratamento com acriflavina, foram acentuadas.

Visando determinar se estas características fenotipicas são transferidas em alta frequencia, foi realizada fusão de protoplastos intraespecífica com $\underline{\text { S }}$ felleus IA-M3079, em decorrência da obtenção de mutantes morfológicos nesta linhagem.

A variante AF3079(90/57), por ser estável e não produzir pigmento, foi usada como receptora, enquanto que a linhagem selvagem de S, felleus IA-M3079 produtora de pigmento amarelo foi inativada pelo calor e utilizada como doadora.

4.4.1. Formação e regeneração de protoplastos de linhagens para a fusão

Foram obtidos protoplastos de Se felleus IA-M3079 produtora de actinomicina (act $\left.{ }^{+}\right)$e da variante AF-3079(90/57) não produtora de actinomicina (act ${ }^{-}$). As frequências de regenerą̧ão das duas linhagens estão expressadas na Tabela 10 . 
Tabela 10

Formação e frequência de regeneração dos protoplastos das

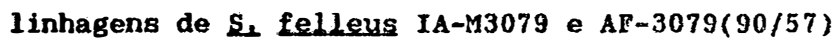

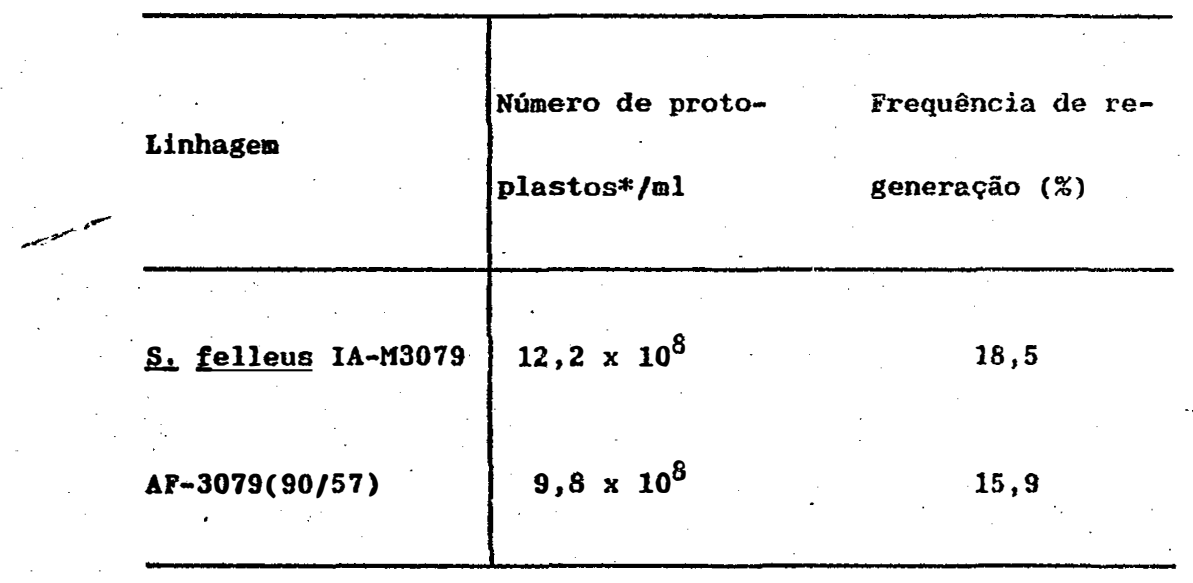

* Média de dois experimentos

A frequência de regeneração de protoplastos obtidos neste trabalho $(18,5$ e $15,9 \%)$ pode ser atribuída à concentração de glicina usada $(0,6 \%)$. Esta concentração permitiu a obtenção de microcolônias com formação de protoplastos dentro de 20 a 30 minutos e células não protoplastizadas na ordem de 0,6 a $0,8 \%$ em ambas as linhagens .

OKANISHI et alii (1974) cultivaram $S$. griseus ISP 5236 e senezuelae ISP 5230 em meio líquido s com $0,8 \%$ e $2,0 \%$ de glicina, respectivamente, e após tratamento com lisozima e enzima lítica no 2 por 1 a 2 
horas obtiveram suspensão de protoplastos contendo de $15 \mathrm{x}$ $10^{8}$ a $17 \times 10^{8}$ protoplastos/ml e regeneração de $41 \%$ e $51 \%$. OGAWA et alii (1983), utilizando o meio $\mathrm{s} 16 \mathrm{com} 0,3 \%$ de glicina, cultivaram S. hrgroscopicus ATCC 21705 por 20-24 horas e realizaram tratamento combinado com lisozima mais acromopeptidase e observaram frequência de regeneração em torno de 15\%. BALTZ (1978), além da adição de glicina ao meio-dé germinação para cultivo de $S$ e fradiae e s. griseofuscus, utilizou como inóculo fragmentos de micélio tratado por ultrassom e observou boa formação de protoplastos no fim da fase exponencial de crescimento, enquanto era evidente um declínio na regeneração quando os protoplastos eram obtidos na fase estacionária. Adicionalmente, HOOLEY \& WELLINGTON (1985), cultivando sete diferentes isolados de $S$ hygroscopicus em meio líquido complexo por sete dias e tratamento com lisozima (1-2 horas), obtiveram suspensão de protoplastos em torno de $10^{6}$ a $10^{8} / \mathrm{ml}$, enquanto a frequência de regeneração ficou abaixo de $5 \%$ para cinco isolados e, em torno de $28 \%$ e $15 \%$, para os demais. ARAUJO et alii (1984/85) cultivaram $\underline{\text { S. }}$ melanochromogenes IA-M3183 em meio $S$ (OKANISHI et alii, 1974 ) com $0,5 \%$ de glicina e S, capoamus IA-M3122 em meio líquido complexo com $0,3 \%$ de glicina por 18 e 24 horas, respectivamente, e após tratamento com lisozima (30-40 minutos) obtiveram suspensão contendo em torno de $10^{8}$ 
protoplastos/ml. SHIRAHAMA et alii (1981), procurando estabelecer " melhores condições para regeneração de.

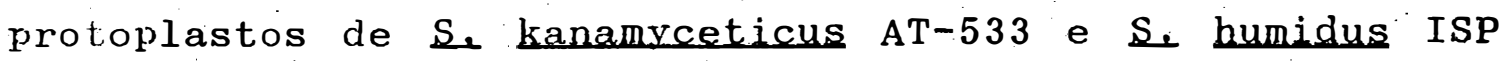
5263 , observaram regeneração em torno de $30 \%$ e $10 \%$, respectivamente.

Ficou muito difícil estabelecer comparações entre aqueles trabalhos e este, uma vez que as condições para formação e regeneração de protoplastos são específicas para cada linhagem, como foi constatado pelo trabalho de HOOLEY \& WELLINGTON (1985) com diferentes isolados de $\underline{S}$ hvgroscopicus.

Pela análise destes trabalhos, fica clara a importância da formação de microcolônias na fase exponencial de crescimento, que facilita a ação da lisozima e as células encontram-se em estado fisiológico ativo, promovendo, consequentemente, uma eficiente regeneração.

4.4.2. Processo de fusão de protoplastos

Neste trabalho, após regeneração da mistura de fusão, 175 clones foram isolados e analisados quanto à formação de pigmento e halo de inibição para B. subtilis JA-16, como descrito no item 3.9 .7 .

Os resultados apresentados na tabela 11 mostram a ocorrência de $0,57 \%$ de produto de fusão. $\dot{A}$ tranteréncia de pigmento amarelo não foi observada entre 
os clones analisados, como era esperado. Entretanto, foi isolada uma colônia com maior diâmetro, que produziu pigmento azul-violáceo e halo de inibição para B. subtilis IA-16. Após subculturas, esta colônia deixou de apresentar halo de inibição.

Tabela 11

Colónias isoladas após fusão de protoplastos e ensaiadas quanto à formação de pigmento e halo de inibição para Bacillus subtilis IA-16

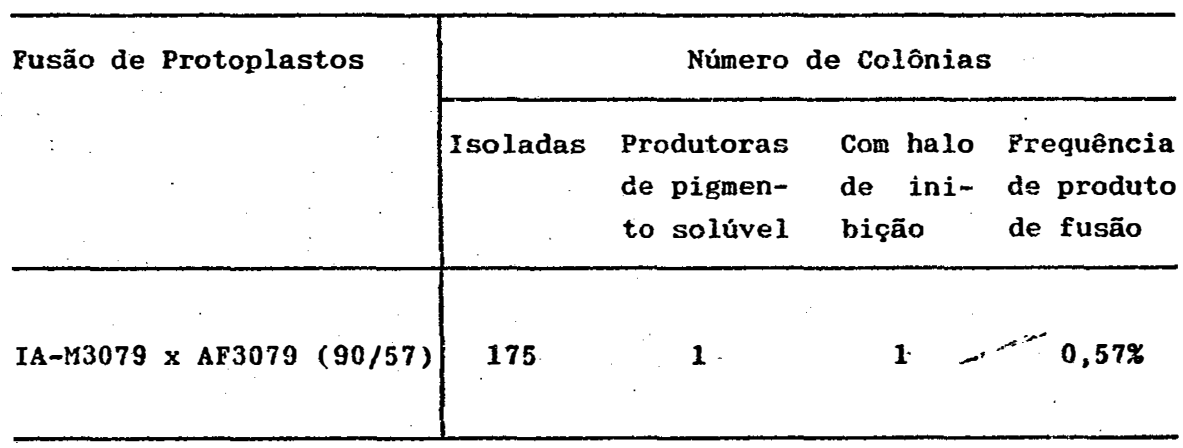

Tabela 12

Caracterfsticas fenotípicas dos clones obtidos após fusão de protoplastos

\begin{tabular}{|c|c|c|c|c|}
\hline $\begin{array}{c}\text { Clones } \\
\%\end{array}$ & $\begin{array}{l}\text { Micélio } \\
\text { aéreo }\end{array}$ & $\begin{array}{l}\text { Formação de pig- } \\
\text { mento solúvel }\end{array}$ & $\begin{array}{l}\text { Diâmetro das } \\
\text { colônias (min) }\end{array}$ & $\begin{array}{l}\text { Halo de inibição } \\
\text { para R. Subtilis } \\
\text { (em mm) }\end{array}$ \\
\hline 99,4 & Branco & Ausente & 3 a 5 & Ausente \\
\hline 0,6 & Cinza & Azul violáceo & 8,0 & $12-18$ \\
\hline
\end{tabular}


Pela análise da literatura, depreende-se que a frequência de produto de fusão está diretamente relacionada à concentração de PEG utilizada, sendo esta concentração independente do peso molecular.

A fusão com S. coelicolor A3(2) usando PEG $15 \%$ a $42 \%$ (peso/volume) adicionado de DMSO (dimetil sulfóxido) rendeu $5 \%$ a $6 \%$ de recombinantes prototróficos, como foi relatado por HOPWOOD et alii (1977). Posteriormente, HOPWOOD \& WRIGHT (1979) comprovaram que PEG 1000 a $50 \%$ sem DMSO promove recombinação superior a $20 \%$ em S. coelicolier, enquanto PEG 6000 tem originado baixa frequência de recombinação (BALTZ, 1978; BALTZ \& MATSUSHIMA, 1981; HRANUELI, 1983), possivelmente pela sua alta viscosidade, como sugerido por HOPWOOD (1981).

Segundo HOPWOOD et alii (1985b) em torno de $50 \%$ é uma ótima concentração para a fusão em streptomyces, sendo verificada baixa frequência de fusão em concentrações abaixo de $40 \%$ e acima de 60\%. Afirmam, ainda, aqueles autores, que o PEG 6000 mostra desvantagem por sua alta viscosidade e dificuldade em sua eliminação após o tratamento de fusão, o que é prejudicial, pois o PEG é tóxico.

A perda de caracteres apresentada pelo clone azul-violáceo não é ímpar na literatura. HOTA et alii (1985) trabalharido com fusão de protoplastos 
interespecífica de mutantes não produtores de antibióticos aminoglicosídicos - S. griseus $\left(\mathrm{EST}^{\mathrm{R}}\right)$ e $\mathrm{S}$ tenjimariensis $\left(\mathrm{KM}^{\mathrm{R}}\right)$ - mostraram que o clone $\mathrm{SK} 52-52\left(\mathrm{EST}^{\mathrm{R}} \mathrm{KM}^{\mathrm{R}}\right)$ produzia um novo antibiótico, entretanto após algumas transferências ocorria segregação de colônias grandes, as quais progressivamente deixavam de produzir o antibiótico. Contudo o clone $\mathrm{SK} 52-52\left(\mathrm{EST}^{\mathrm{R}} \mathrm{KM}^{\mathrm{R}}\right)$ permanecia com a mesma resistência a estreptomicina e a kanamicina induzida pela fusão de protoplastos, mostrando-se instável para a produção do novo antibiótico, possivelmente devído a pouca homologia entre as espécies.

HOPWOOD et alii (1977) e HOPWOOD \& WRIGHT (1978) afirmam que a regeneração pós-fusão de protoplastos em condições não seletivas, ainda que com linhagem auxotrófica, aumenta o número de eventos de fusão e proporciona maior frequência de recombinação. Isso decorre de múltiplas permutas, ocasionadas pela união de genomas completos em uma mesma unidade celular, seguidas de fragmentação e perda de segmentos de um ou ambos os genomas, resultantes de um estado diplóide transitório. 
4.5. Estabilizạão dos setores

O clone heterocariótico que mostrava halo de inibição para B. subtilis $I A-16$ foi semeado em quatro pontos em placas com meio de esporulação (ME) e, até cinco dias de cultivo, as colônias apresentavam formação de piginento azul-violáceo (Figura 9).

Após 14 dias de cultivo, as colônias resultantes da semeadura em quatro pontos, $\mathrm{Pf}_{1}, \mathrm{Pf}_{2}, \mathrm{Pf}_{3} \mathrm{e}$ $\mathrm{Pf}_{4}$, segregaram vários setores (Figura 10), os quais foram estabilizados através de semeadura em. meio ME e designados de acordo com o fenótipo (Tabela 13).

A análise dos clones estabilizados está contida na Tabela 14 e mostra que o setor Smb é o mais frequente, uma vez que entre 24 colônias de $\mathrm{Pf}_{3}$ analisadas, $16(66 \%)$ mostraram este setor.

A segregação de setores observada neste trabalho possivelmente resulta do estado diplóide transitório observado por HOPWOOD (1981) em fusão de protoplastos de mutantes auxotróficos de $S$. ceelicolor A $3(2)$.

Estado heterocariótico foi observado por OCHI (1982) após fusão de protoplastos intraespecífica com Iinhagens auxotróficas de $\mathbf{s}$ antibiaticus 3720 . A regeneração em meio mínimo revelou colônias pequenas que segreggavan um dos genotipos parentais, enquanto as colônias 
grandes heterocarióticas eram prototróficas. similarmente, HRANUELI et alii (1983) verificaram fenômeno igual em fusão de protoplastos de S. rimosus ATCC 10970.

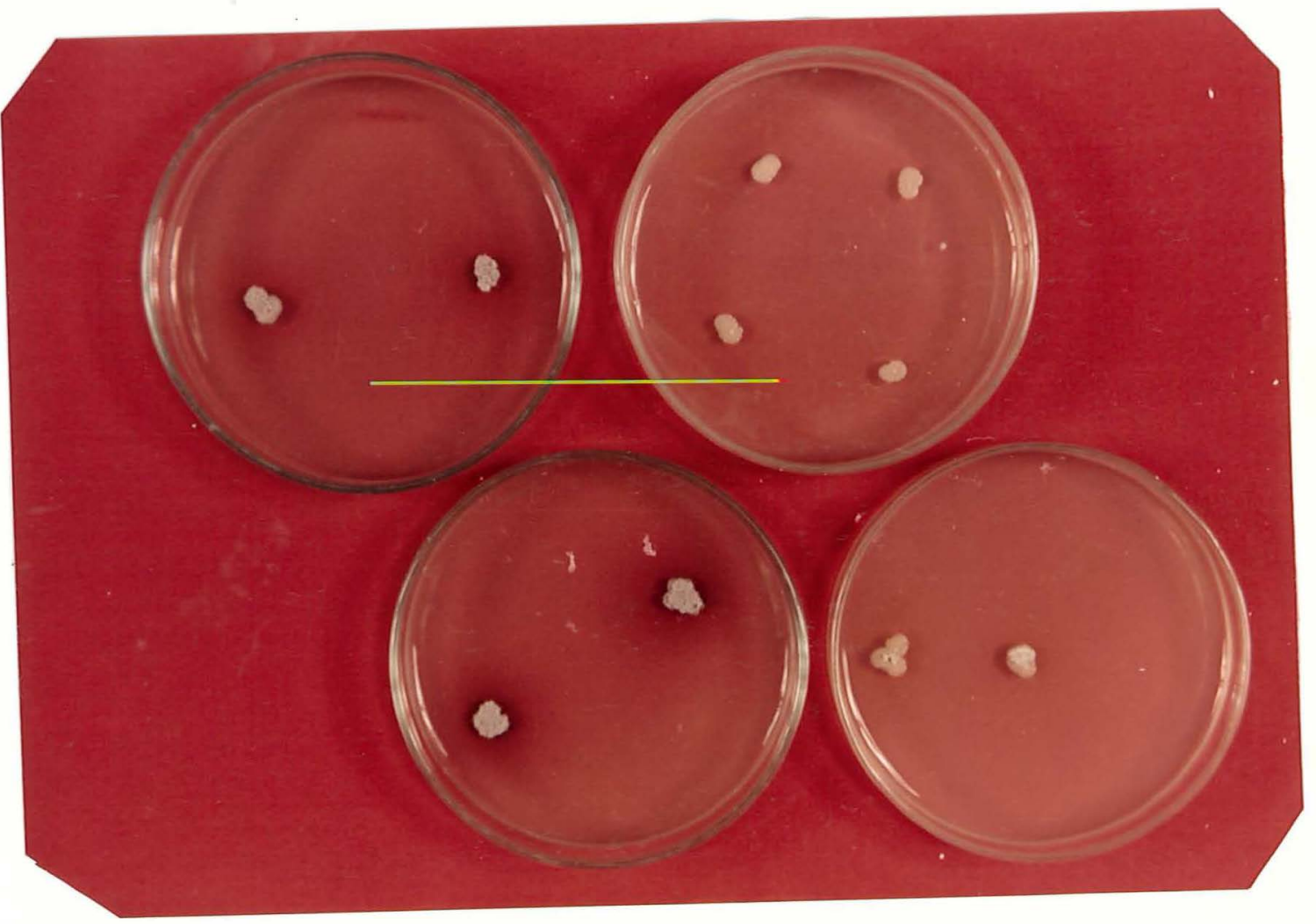

Figura 9. Colônias isoladas a partir do clone recombinante obtido da fusão de protoplastos entre a Linhagen selvagem de Se felleus IA- M3079 e a variantie $A F-3079(90 / 57)$ 


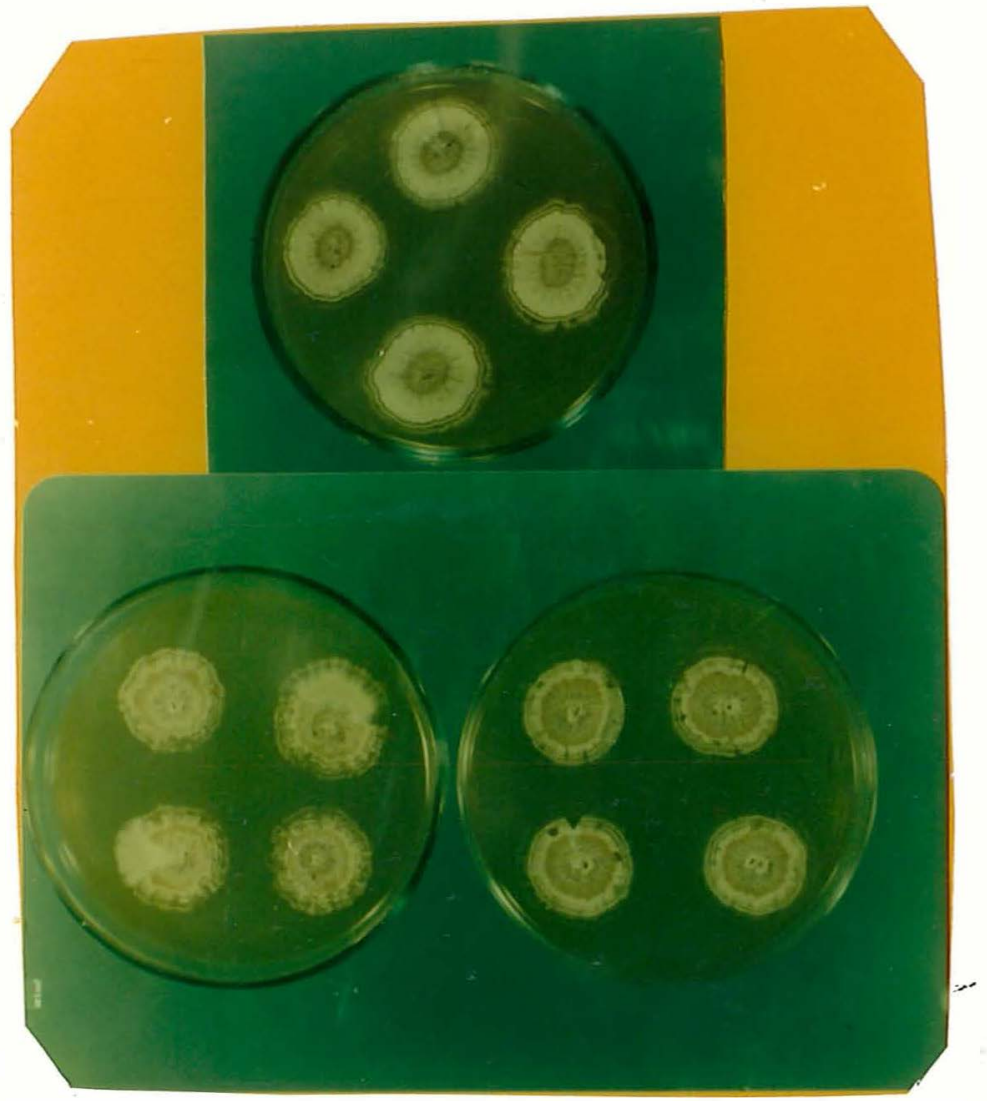

Figura 10. Clones isolados do produto de fusão apresentando formação de vários setores (14 dias de cultivo) 
Tabela 13

Caracteristicas morfológicas dos setores segregantes obtidos da

fusão de protoplastos de S. felleus IA-M3079 x AF-3079 (90/57)

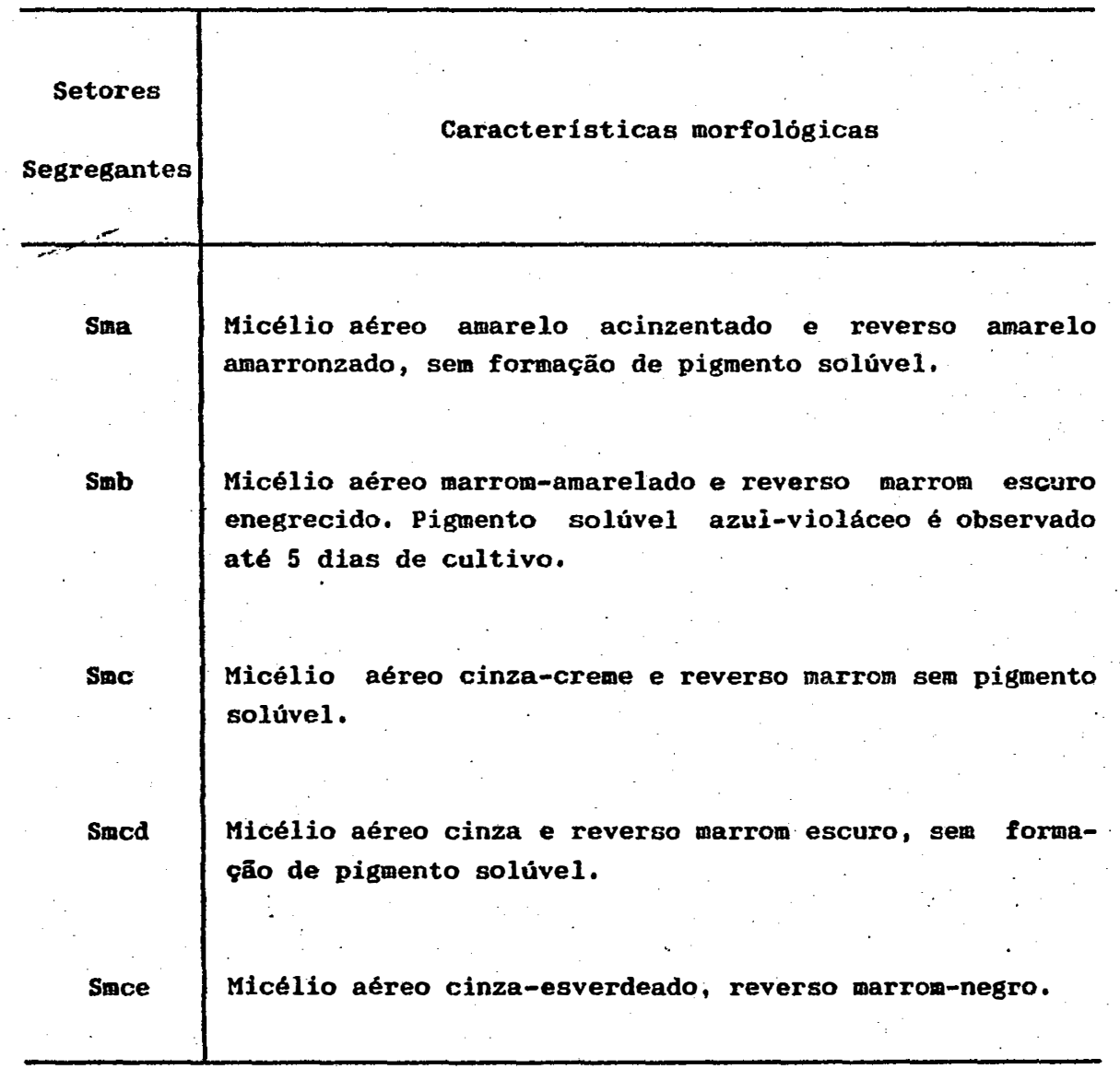


Tabela 14

Frequência de setores recombinantes da fusäo de $\underline{s}_{\text {f }}$ felleus IA-M3079 \& AF3079 (90/57) após 14 dias de cultivo em meio ME

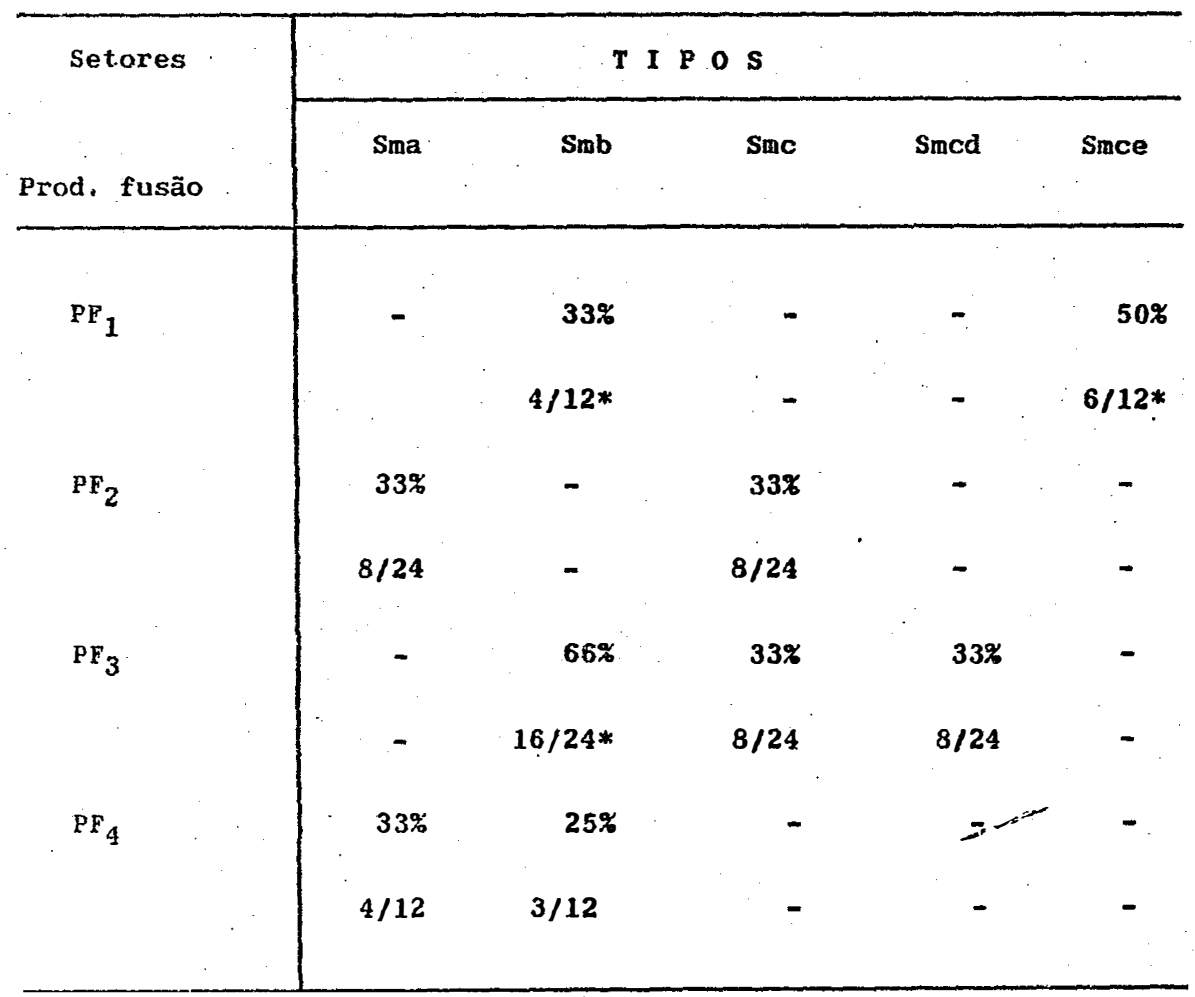

* Número de colônias ensaiadas/número de colônias observadas

4.6. Caracterização dos setores segregantes

4.6.1. Análise dos segregantes quanto a formação fenótipo "pock"

Una vez que a linhagem selvagem de freduriss IA-M3079 mostra a ocorrência de dois elementos 
conjugativos, caracterizados neste trabalho através da morfologia "pock", tornou-se necessário verificar se os setores segregantes obtidos pela fusão de protoplastos são portadores de algum plasmídio conjugativo.

Todos os setores mostraram o mesmo tipo morfológico do fenótipo "pock" (Figura 11), não sendo evidenciado "pock" com grandes zonas de inibição como o observado em S. felleus IA-M3079 (Figura 6).

Estes resultados possivelmente mostram a transferência de um dos plasmídios conjugativos de $\underline{\text { S. }}$ felleus IA-M3079, produtor de actinomicina, para o mutante AF-3079(90/57), não produtor de actinomicina, através da fusão de protoplastos; entretanto não foi observada elevada transferência de pigmento amarelo-laranja.

Pode acontecer que estas características fenotópicas não estejam relacionadas com elemento extracromossômico ou, ainda, este elemento pode conter apenas genes reguladores da produção de actinomicina. 


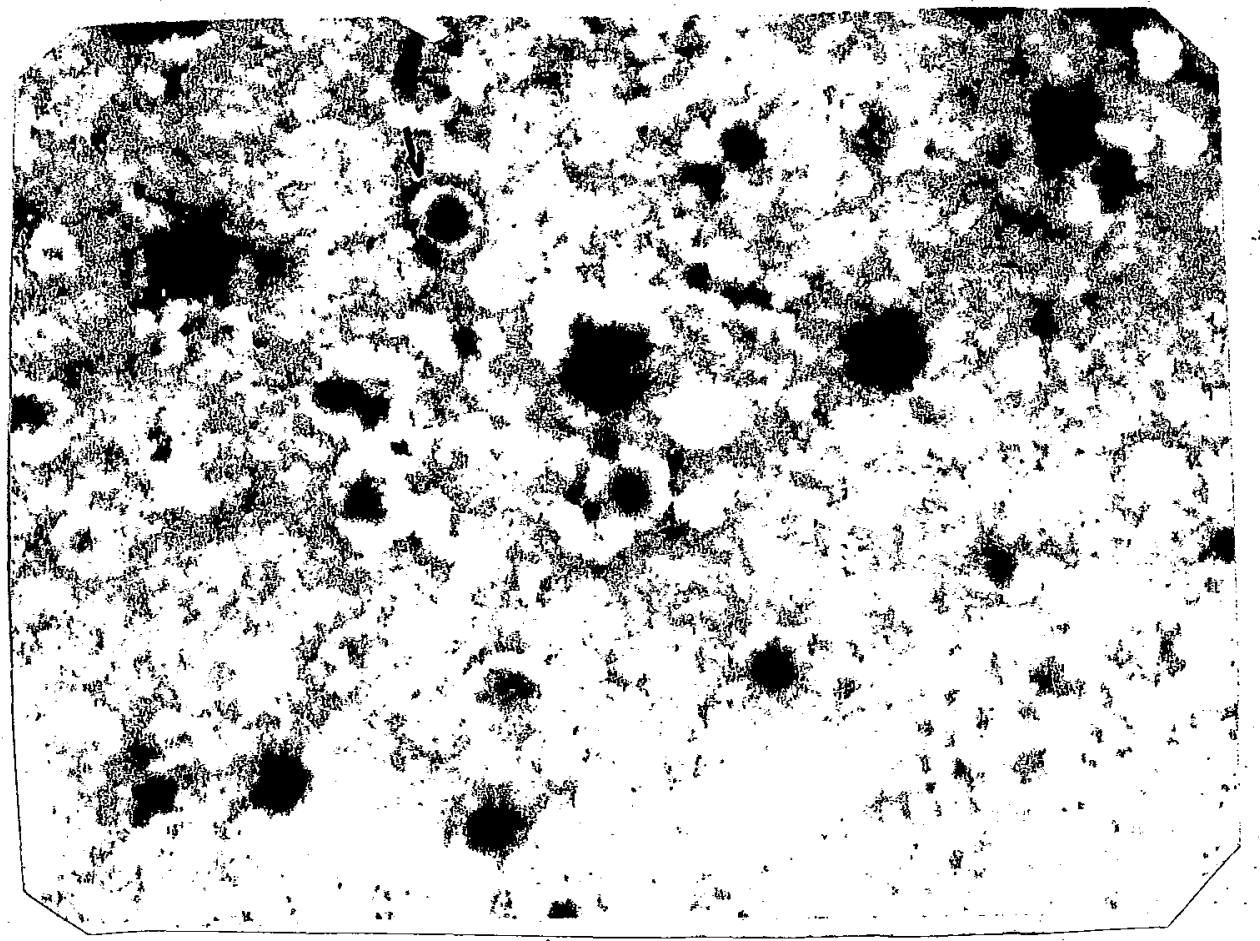

Figura 11. Fenótipo "pock" do setor recombinante Smc em um "background" de S, lividans. TK24 livre de plasmídios (aumento 40x)

O mecanismo de produção e de regulação de actinomicina ainda não é completamente entendido. Em $\underline{S}$ antibioticus e S. parvulus tem sido sugerido o envolvimento de plasmídios na biossíntese da actinomicina, enquanto que em S. chrysomallus ATCC 11523 estudos realizados por HAESE 
\& KELLER (1988) revelam que genes biossintéticos de actinomicina estão localizados no cromossomo.

Neste trabalho, a obtenção de setores segregantes que não produzem actinomicina decorre possivelmente da inativação de genes estruturais ou genes reguladores localizados sobre plasmídio e, . quando transferidos, ativam genes cromossomais para produção de outro pigmento - o azul-violáceo - e não o pigmento amarelo relacionado com actinomicina. Segundo HOPWOOD (1981c), a transferência de plasmídios nativos contendo genes reguladores para um novo hospedeiro poderá levar expressão de novas viás biossintéticas.

4.6.2. Análises dos setores segregantes quanto às características fisiológicas e morfológicas

Em decorrência dos setores segregantes obtidos da fusão de protoplastos apresentarem formação de pigmento distinto daquele do parental - S. felleus IA-M3079 - foram analisadas as características fisiológicas e morfológicas destes setores, visando determinar similaridades ou diferenças entr.e os mesmos.

Streptomyces felleus (Lindenbein) foi descrito inicialmente em 1952 por Lindenbein e redescrito por SHIRLING \& GOTTLIEB (1968a) através do "International 
Streptomyces Project" e, de acordo com a cor do micélio aéreo, esta linhagem pertence à Série Amarela.

A Iinhagem IA-M3079, utilizada neste trabalho foi isolada de amostras de solo da cidade do Recife e classificada como $s$ felleus (FALCAO DE MORAIS ${ }^{1}$ ).

A observação da Tabela 15 mostra que manitol. e ramnose são utilizados por S. felleus IA-M3079, enquanto a sua variante $\mathrm{AF}-3079(90 / 57)$ não utiliza estes açúcares, não sendo detectadas diferenças para os outros açúcares nestas linhagens. Para os setores recombinantes, manitol é utilizado como fonte de carbono, o que não ocorre em ramnose. Estes resultados mostram que os recombinantes adquiriram a propriedade de assimilação de manitol do parental "doador" S. felleus. IA-M3079.

Outras propriedades bioquímicas ensaiadas, como hidrólise da gelatina e do amido, mostraram comportamentos iguais para todas as linhagens, do mesmo modo que pigmentos melanóides não foram formados en meios padronizados (Tabela 16 ). 
Tabela 15

Utilização de fontes de carbono nas linhagens parentais de

S. felleus IA-M3079 e M3079 (90/57) e dos setores segregantes obtidos por fusão de protoplastos

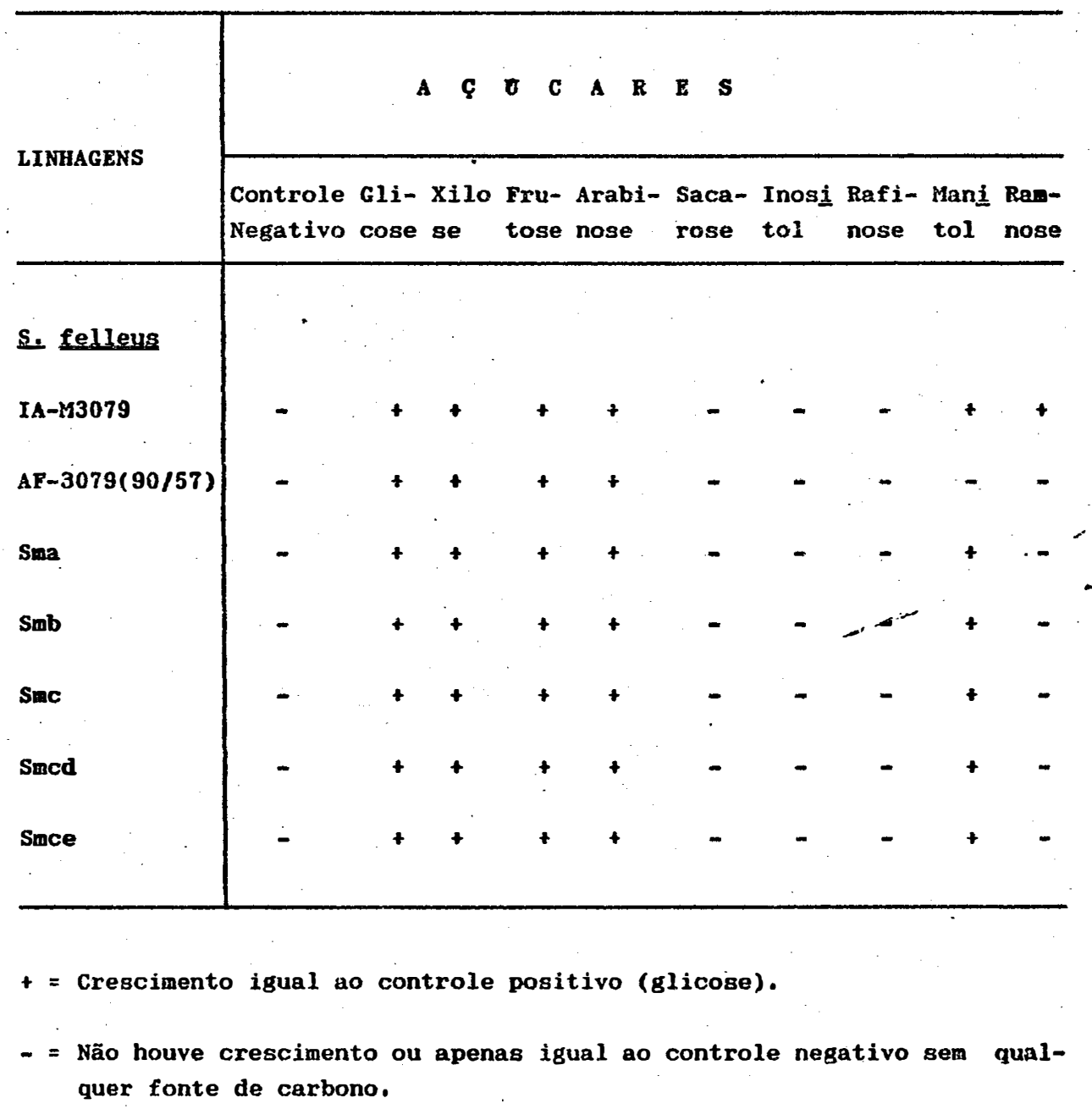


Tabela 16

$$
\begin{gathered}
\text { Propriedades bioquimicas das linhagens parentais de } S_{\text {felleys }} \\
\text { IA-M3079 x } 3079(90 / 57) \text { e dos setores segregantes obtidos } \\
\text { por fusão de protoplastos }
\end{gathered}
$$

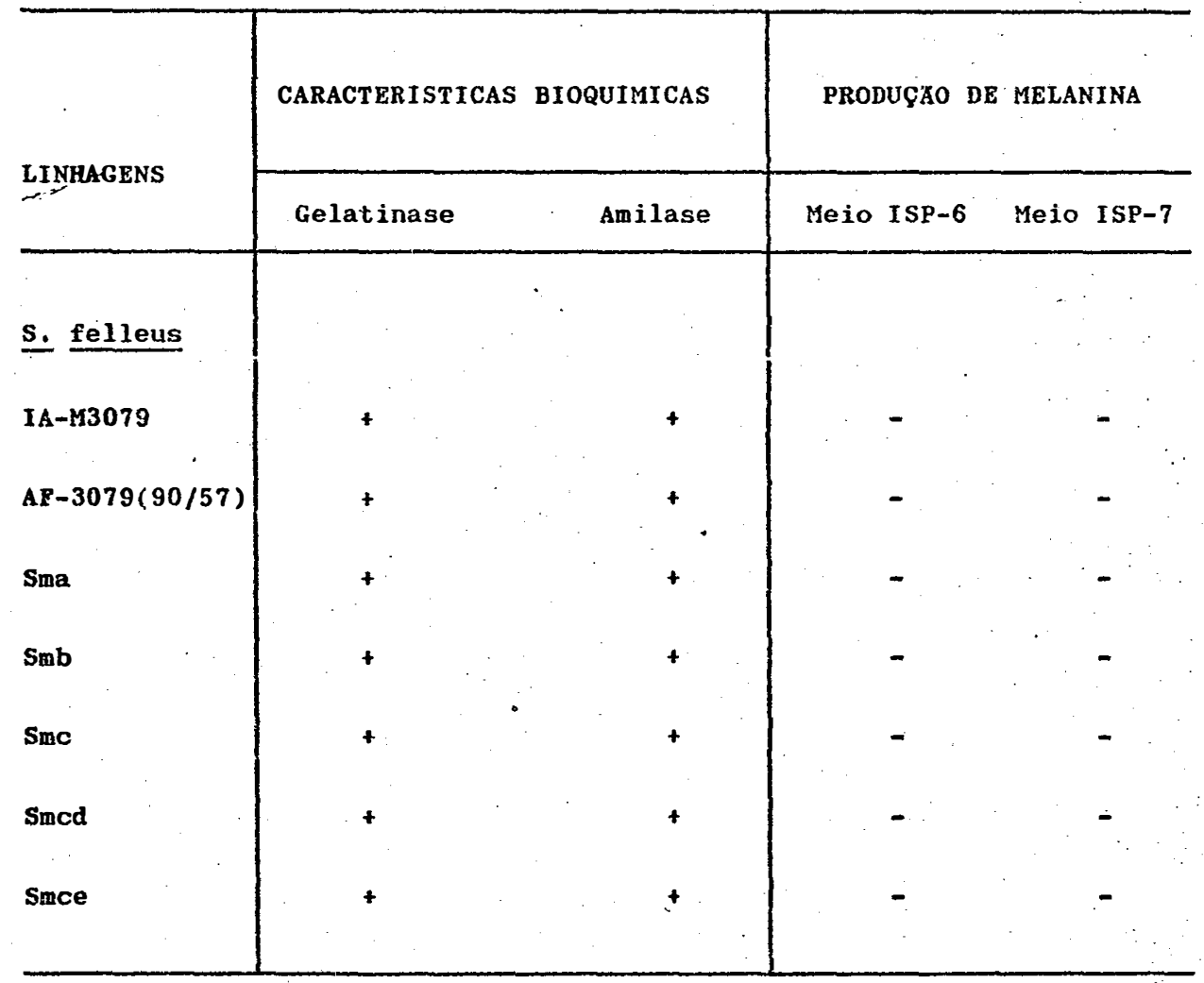

+ = degradação enzimática

- = não produtora de pigmento melanínico

A tolerância a cloreto de sódio observada na Tabela 17 mostra que na concentração de $10 \%$ não ocorre crescimento das linhagens parentais, enquanto que os 
setores : recombinantes crescem fracamente nesta concentração, possivelmente em decorrância de alterações na permeabilidade da membrana.

As propriedades fisiológicas dos setores também mostram estreita similaridade com aquelas dos seus parentais $S$ felleus IA-M3079 e AF3079(90/57). Adicionalmente, não foi observada qualquer diferença marcante entre estas linhagens. Investigação similar foi realizada por HOTTA et alii (1985) na caracterização do clone SK2-52 obtido por fusão de protoplastos interespecifica entre $S_{\text {, griseus }}\left(S t r^{R}\right)$ e $S_{\text {e }}$ tenjimariensis $\left(K M^{R}\right)$. As propriedades morfológicas e bioquímicas de SK2-52 eram similares às do $S$. griseus $\left(S t r^{R}\right)$. Do mesmo modo, as resistências à estreptomicina e a outros aminoglicosídios se originaram, segundo aqueles autores, da linhagem de $\underline{s}$ griseus $\left(\operatorname{EST}^{\mathrm{R}}\right)$.

Estas observações corroboram as decorrentes deste trabalho, onde foi constatado, pelas características bioquímicas dos setores segregantes, elevado grau.de similaridade com os parentaj.s. 
Tabela 17

Tolerância a cloreto de sódio apresentada pelas linhagens parentais

S. felleus IA-M3079 x AF3079 (90/57) e dos setores segregantes

obtidos por fusāo de protoplastos

\begin{tabular}{|c|c|c|c|c|c|}
\hline \multirow{2}{*}{ Z̃NHAGENS } & \multicolumn{5}{|c|}{ CONCENTRAÇAO DE NaCl (g\%) } \\
\hline & 0,0 & 4,0 & 7,0 & 10,0 & 13,0 \\
\hline s. felleus & & & & & \\
\hline IA-M3079 & $+t$ & $+t$ & $+t$ & - & - \\
\hline$A F-3079(90 / 57)$ & $+t$ & $+t$ & $+t$ & - & - \\
\hline Sma & ++ & $+t$ & ++ & + & - \\
\hline SqBb & $t+$ & 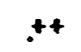 & ++ & + & - \\
\hline Sac & ++ & ++ & ++ & + & - \\
\hline Smcd & $+t$ & ++ & $t+$ & + & - \\
\hline Since & $+t$ & ++ & +4 & + & $\therefore$ \\
\hline
\end{tabular}

t+ = Bom crescimento

$+=$ Crescimento regular

- = Sem crescimento

Com o objetivo de verificar se a fusão de protoplastos intraespecífica em s. felleus IA-M3079 
originou a formação de novos genótipos, foram realizados testes auxotróficos com os setores segregantes. Os parentais são prototróficos, enquanto os setores exibiram auxotrofia para adenina. Estes resultados comprovam que a recombinação por fusão de protoplastos permitiu aumentar a variedade genética nesta linhagem sem a utilização de agentes mutagênicos (Tabela 18).

Tabela 18

Auxonografia dos parentais S. felleus IA-M3079 x AF-3079(90/57) e dos getores segregantes, obtidos por fusão de protoplastos

\begin{tabular}{l|c}
\hline \multicolumn{1}{c|}{ LINHAGENS } & EXIGENCIA IUTRICIONAL \\
\hline S. felleus IA-M3079 & Prototrófica \\
Ar-3079(90/57) & Prototrófica \\
Sma & Adenina \\
Smb & Adenina \\
Smcd & Adenina \\
Sumce & Adenina \\
\hline
\end{tabular}


Isto só foi possível utilizando a inativação de um dos parentais (doador morto) no processo de fusão, permitindo seleção de recombinantes. Segundo BALTZ (1978), não é aconselhável a indução de mutantes em linhagem de interesse econômico, em decorrência da acumulação de mutações crípticas que mostram efeito pleiotrópico negativo sobre a produção de antibióticos, além de mascarar o efeito benéfico das novas combinações de genes (QUEENER \& BALTZ, 1979; NORMANSELL, 1982 ).

Estudo comparativo das características morfológicas de $\mathrm{S}$. felleus IA-M3079, da variante AF$3079(90 / 57)$ e dos setores segregantes Sma e Smcd está contido na Tabela 19.

Através destes estudos pode ser observado que as nuances de coloração do micélio aéreo dos setores (amarelo-cinza) estão próximas da cor da massa micelial da linhagem parental (amarelo-cinza pálido). A cor do reverso dos setores segregantes no meio ISP-5 apresenta uma tonalidade amarelo-ferruginosa mais intensa que a observada nos parentais.

A observação micromorfológica de $\underline{\text { S. felleus }}$ IA-M3079 mostra cadeias de esporos da Seçã̃o Rectiflexibiles (RF) (PRIDHAM et alii, 1958), igualmente como a variante e os setores recombinantes, que apresentam esporóforos com 10 a 30 esporos. 
Pabela 19

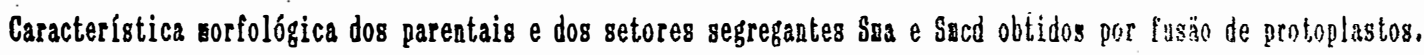

\begin{tabular}{|c|c|c|c|c|c|}
\hline \multirow{2}{*}{$\begin{array}{l}\text { RBIOS DB } \\
\text { CULTURA }\end{array}$} & \multirow{2}{*}{$\begin{array}{l}\text { CARACPRBISSPI- } \\
\text { CAS\$ }\end{array}$} & \multicolumn{4}{|c|}{$L I \& A \& \& \| S$} \\
\hline & & $\left\{\begin{array}{l}\text { IL-43079 } \\
\text { s. fellens }\end{array}\right.$ & $\begin{array}{l}\text { Variante } \\
\text { AR } 3079(90 / 57)\end{array}$ & Sra & Sacd \\
\hline $\begin{array}{l}\text { ISp-? Extrato } \\
\text { de levedura- } \\
\text { ágar }\end{array}$ & $\mid \begin{array}{l}\text { reverso } \\
\text { piga. solúvel }\end{array}$ & $\begin{array}{l}\text { Bol } \\
\text { Abundante } \\
\text { Lararelo/Cinza } \\
\text { (2ba } 11 / 2 d b) \\
\text { Arar ararronz. } \\
\text { Ararelo claro }\end{array}$ & 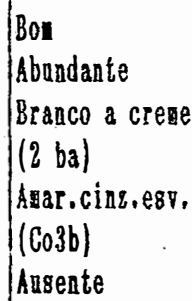 & $\begin{array}{l}\text { Boy } \\
\text { Praco } \\
\text { Awar,-cinz-cr. } \\
\text { (2ba 1ba) } \\
\text { Anar, esverd, } \\
\text { (Co3b Co3s) } \\
\text { Agarelo claro }\end{array}$ & $\begin{array}{l}\text { Boo } \\
\text { Rraco } \\
\text { Cr.cinza/agaa. } \\
(1 \text { ba-1 1/2db) } \\
\text { Alarelo-garcod } \\
\text { Anarelo claro }\end{array}$ \\
\hline $\begin{array}{l}\text { ISP-3 } \\
\text { Aveia-ágar }\end{array}$ & $\begin{array}{l}\text { Crescinento } \\
\text { Uicélio aéreo } \\
\text { Reverso } \\
\text { Pign. solóvel }\end{array}$ & 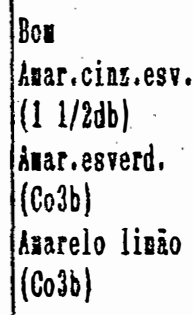 & $\begin{array}{l}\text { Bor } \\
\text { Arar.cinz.est. } \\
(1 . c b) \\
\text { Crene pálido } \\
(\text { Co a }) \\
\text { Ausente }\end{array}$ & $\begin{array}{l}\text { Bon } \\
\text { Anar, cinz. esp. } \\
(1 \text { ba-a } 1 / 2 \text { db) } \\
\text { Ataralo claro } \\
\text { (Co a) } \\
\text { Anarelo claro }\end{array}$ & 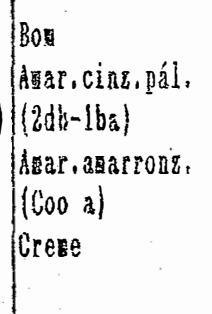 \\
\hline $\begin{array}{l}\text { ISP-4 } \\
\text { Asido-sais } \\
\text { inorgânicos- } \\
\text { ágar }\end{array}$ & $\begin{array}{l}\text { Crescinento } \\
\text { Ricélio aéreo } \\
\text { Reverso } \\
\text { Pign. solóvel }\end{array}$ & $\begin{array}{l}\text { Bor } \\
\text { Arar, pálido } \\
\text { (2db-2ba) } \\
\text { Ararelo claro } \\
\text { (Co a) } \\
\text { Ausente }\end{array}$ & 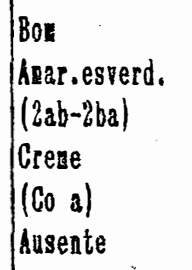 & $\begin{array}{l}\text { Bor } \\
\text { Anar. esverd. } \\
\text { (1cb/2db) } \\
\text { drar. varroa } \\
\text { (Coor) } \\
\text { Ausente }\end{array}$ & 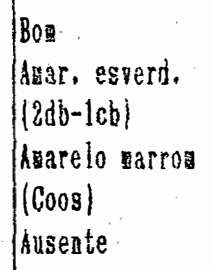 \\
\hline $\begin{array}{l}\text { ISP-5 } \\
\text { Glicerol- } \\
\text { asparagina- } \\
\text { agar }\end{array}$ & $\begin{array}{l}\text { Crescinento } \\
\text { Hicélio aéreo } \\
\text { Reverso } \\
\text { Pign. solável }\end{array}$ & $\begin{array}{l}\text { Bor } \\
\text { Alar. esverd. } \\
(1 \mathrm{c} b) \\
\text { Cr-ararelado } \\
(\text { Coosb) }\end{array}$ & $\begin{array}{l}\text { Bos } \\
\text { Cinz,esbranq. } \\
\text { (1ba) } \\
\text { Branco }\end{array}$ & $\begin{array}{l}\text { Bon } \\
\text { Anar. cinz,palle } \\
(2 b a-2 \text { ib }) \\
\text { Anar, ferrug. } \\
(\text { Ocr })\end{array}$ & 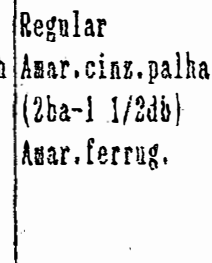 \\
\hline
\end{tabular}

* Classificação das cores de acordo con o kétodo adotado pelo ISP (iten 3.5 .4 ).

A microscopia eletrônica de transmissão da superfície dos esporos foi realizada no Laboratório de 
Imunopatologia Prof. Keizo Asami (UFPE) e mostrou superfície lisa para as linhagens parentais e para os setores segregantes (Figura 12 ).

Estas propriedades morfológicas são consistentes com aquelas observadas em S. felleus IA-M3079 e em AF3079(90/57).

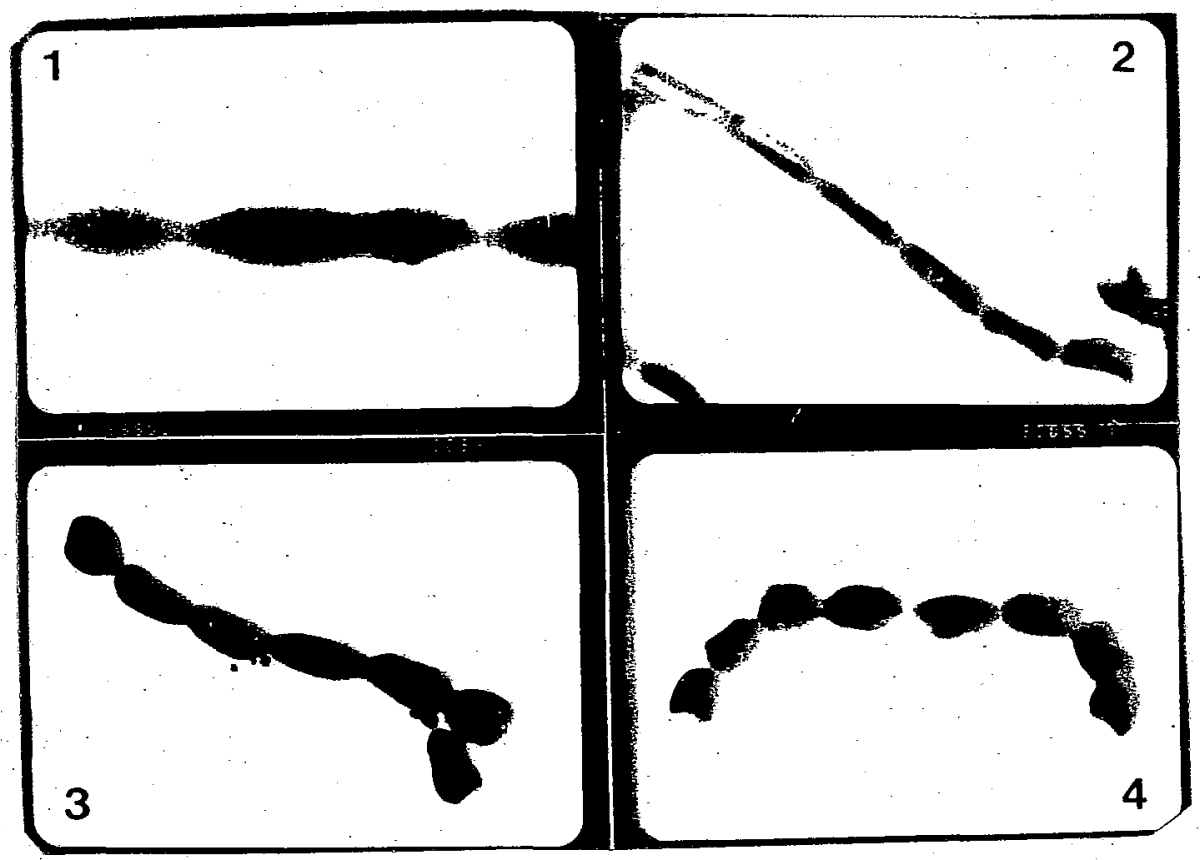

Figura 12. Microscopia eletrônica de transmissão da superfície dos esporos das linhagens parentais e dos setores recombinantes: $1=S$, felleus IA-M3079; $2=\operatorname{AF3079}(90 / 57) ; 3=\operatorname{Sma} ; 4=\operatorname{Smc}$ 
4.6.3. Teste de resistência a antibióticos

Os níveis de resistência aos diferentes antibióticos apresentados na Tabela 20 mostram que os setores recombinantes são altamente sensíveis a actinomicina $(<5>1 \mu \mathrm{g} / \mathrm{ml})$, enquanto $\mathrm{S}$. felleus IA-M3079, produtor deste antibiótico, apresenta elevada resistência $(>400 \mathrm{\mu g} / \mathrm{ml})$ e a variante $\mathrm{AF}-3079(90 / 57)$ possui uma resistência intermediária $(>150<200 \mu \mathrm{g} / \mathrm{ml})$. Para rifampicina foi observada maior resistência dos recombinantes $(<50>10 \mu \mathrm{g} / \mathrm{ml})$, enquanto os parentais mostraram alta sensibilidade, sendo que a variante $A F-3079(90 / 57)$ foi mais sensível que o parental selvagem S. felleus IA-M3079.

A elevada resistência observada em $\underline{S}$ felleus IA-M3079 para actinomicina demonstra que esta linhagem é produtora desse antibiótico, enquanto que a resistência à penicilina e à anfotericina mostra a potencialidade desta linhagem para a produção de outros antibióticos, como foi demonstrado por XAMASHITA et alii (1985) para linhagens de actinomicetos produtores de antibióticos aminoglicosídicos. Segundo aqueles autores, os actinomicetos possuem um padrão individual de resistência a antibióticos, sendo que linhagens com múltipla resistência apresentam potencialidades para produção de outros antibióticos. 
Tabela 20

Determinação de resistência a diferentes antibióticos pelas linhagens parentais Sis fellells IA-M3079 x AF-3079(90/57) e dos recombinantes da fusão de protoplastos

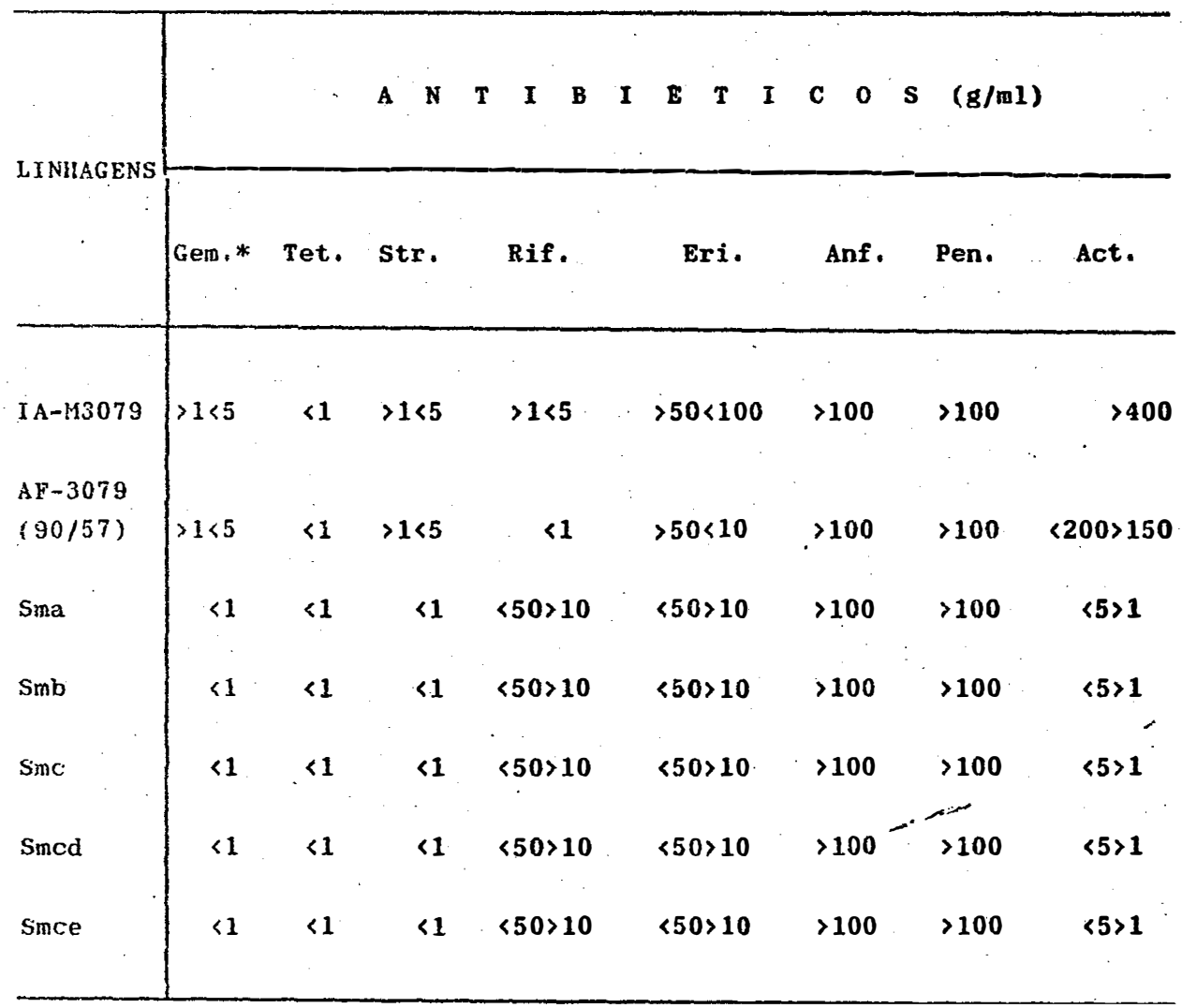

Gem, = Gentamicina

Tet, = Tetraciclina

Str. = Estreptomicina

Rif. = Rifampicina

Eri, = Eritromicina

ii) $f=$ Anfotericina

Pin. = Penicilina

Act. : Actinomicina 
Corroborando estes argumentos, a biologia molecular tẹ demonstrado através de clonagens que genes biossintéticos, regulatórios e de resistência estão organizados em um conjunto (cluster), como foi visto para: estreptomicina, bialofos, eritromicina e actinorrodina (OHNUKI et alii, 1985; DISTLER et alii, 1987; TOYAMA et alii, 1987; MURAKAMI et alii, 1986; STANZAK et alii, 1986; MALPARTIDA \& HOPWOOD, 1984 e 1986).

Neste trabalho, os setores segregäntes obtidos da fusão de protoplastos apresentam elevada sensibilidade à actinomicina, entretanto continuam com o mesmo padrão de resistência à penicilina e à anfotericina que os parentais.

\subsubsection{Comportamento eletroforéticó}

Embora o comportamento eletroforético do padrão de bandas proteicas ainda não tenha sido utilizado como uma técnica auxiliar para detectar similaridades e diferenças entre espécies de Streptomyces , esta técnica já foi usada com êxito para a classificação e identificação de Zymomonas (KERSTERS \& DE LEY, 1975), bem como de Verticillium e Eusarium (WHITNEY et alii, 1968). No presente trabalho foram comparados os padrões de bandas de proteínas para melhor caracterizar os recombinantes. 
Segundo PACCOLA-MEIRELLES (1988), a caracterização eletroforética é um instrumento indispensável em programas de melhoramento, uma vez que possibilita verificar diferenças entre isolados morfologicamente semelhantes com muita facilidade.

As Figuras 13 e 14 mostram o padrão eletroforético para esterases e proteínas totais dos parentais - S.felleus IA-M3079, AF-M3079(90/57) e dos setores segregantes.

Figura 13. Padrão eletroforético para esterases dos parentais S. felleus IA-M3079 x AF-3079(90/57) e dos setores segregantes Sma, Smb e Smc em gel de poliacrilamida
1) S. felleus. IA-M3079
2) S. felleus AF-3079(90/57)
3) Sma
4) $\mathrm{Smb}$
5) S. felleus AF-3079(84/50)
6) Smc 


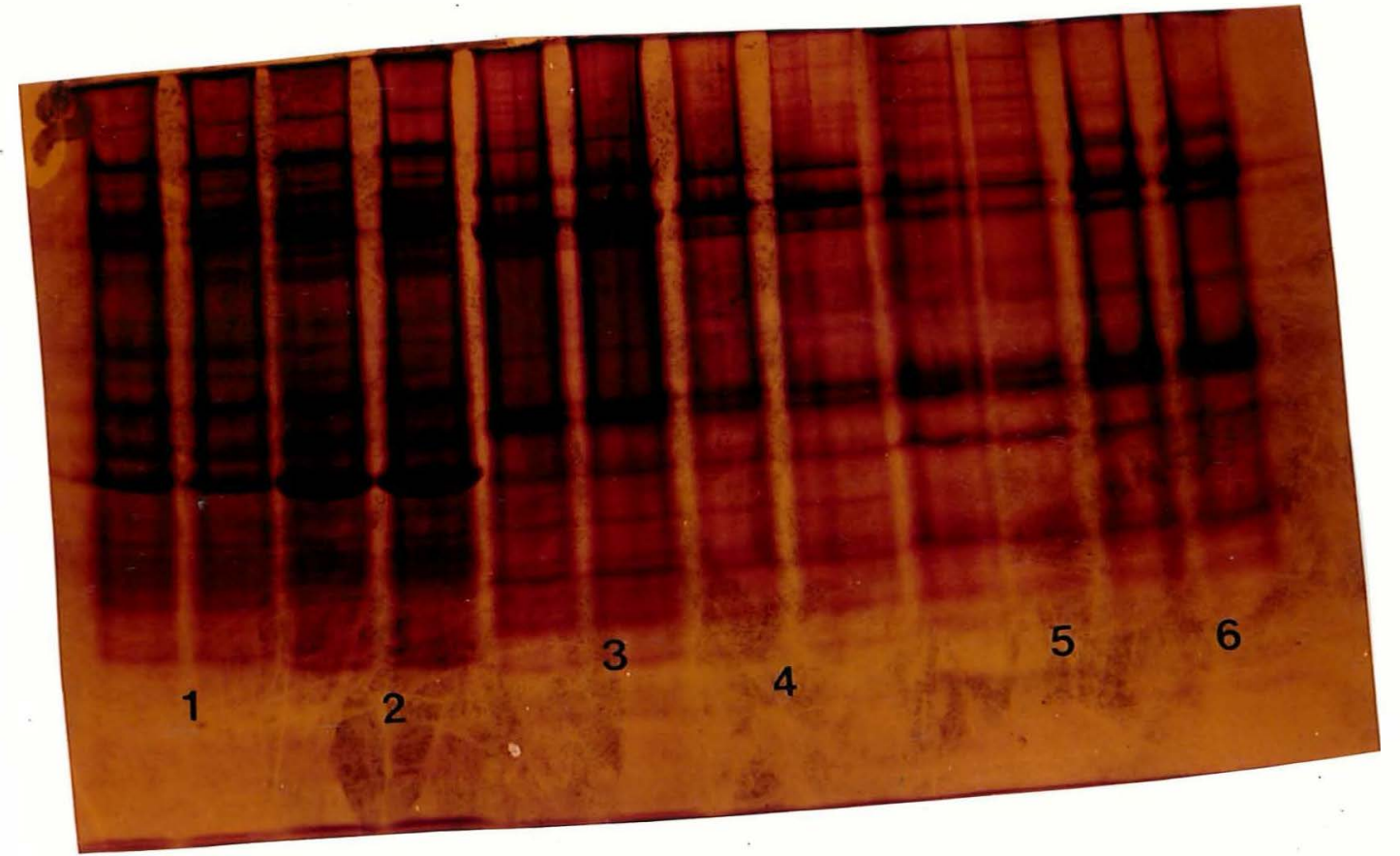

Figura 14. Padrão eletroforético em gel de poliacrilamida para proteínas totais dos parentais $\underline{S}$ feldeus IA-M3079 $\mathrm{x}$ AF-3079(90/57) e dos setores segregantes
1) S. felleus IA-M3079
2) S. felleus AF-3079(90/57)
3) Sma
4) $\mathrm{Smb}$
5) Smc
6) Smcd

A análise do perfil eletroforético para esterases dos parentais mostra a perda de uma banda muito fraca no parental AF3079(90/57) que corresponde à banda com 


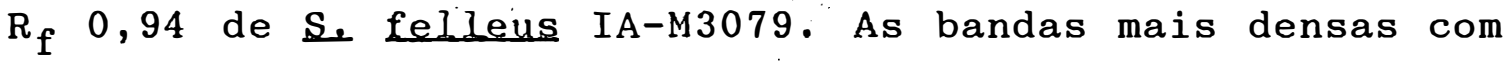
$\mathrm{R}_{\mathrm{f}} 0,8$ e 0,86 são comuns nas duas linhagens. Os setores segregantes apresentam apenas as bandas de $R_{f} 0,99$ e 0,98 similares ao observado em S. felleus IA-3079, indicando ter adquirido estas características do parental "doador".

o padrão eletroforético de proteínas totais dos setores segregantes é muito similar ao observado nos parentais. Apenas a banda com $R_{f}$ em torno de 0,45 nos parentais não é vista nos setores segregantes e duas bandas muito densas com $R_{f} 0,65$ nos parentais se apresentam nos setores com menor mobilidade eletroforética. Apesar destas pequenas diferenças, estes padrões eletroforéticos mostram estreita similaridade dos setores segregantes com os parentais.

4.7. Análise dos setores segregantes quanto à produção de antibióticos

Em razão da formação de outro pigmento que não o pigmento amarelo do parental ("doador") S. felleus IA-M3079, da presença de um elemento conjugativo e, ainda, da variação genética observada na análise da exigência nutritiva, surge a perspectiva de que esta nova linhagem possa estar associada à produção de um outro antibiótico. 
Comi base nestas observações, os setores segregantes foram inicialmente ensaiados para diferentes grupos de microrganismos, como descrito no item 3.6.4. 0 teste preliminar em bloco de gelose de todos os setores mostrou halo de inibição apenas para candida albicans IBB50.

Na Tabela 21 estão contidos os halos de inibição dos líquidos fermentados com 96 horas de cultivo que corresponde ao pico máximo de atividade antagonista nos diferentes grupos' de microrganismos. A análise desta Tabela mostra que os setores Smc e Smcd apresentam halo de inibição de 12,5 e $19,5 \mathrm{~mm}$, respectivamente, para $B_{\text {. }}$ subtilis, bem inferior que o halo mostrado pelo parental S. felleus IA-M3079. 
Testes antimicrobianos dos liquidos fermentados pelos setores segregantes cultivados por 96 horas en meio de produção de antibióticos

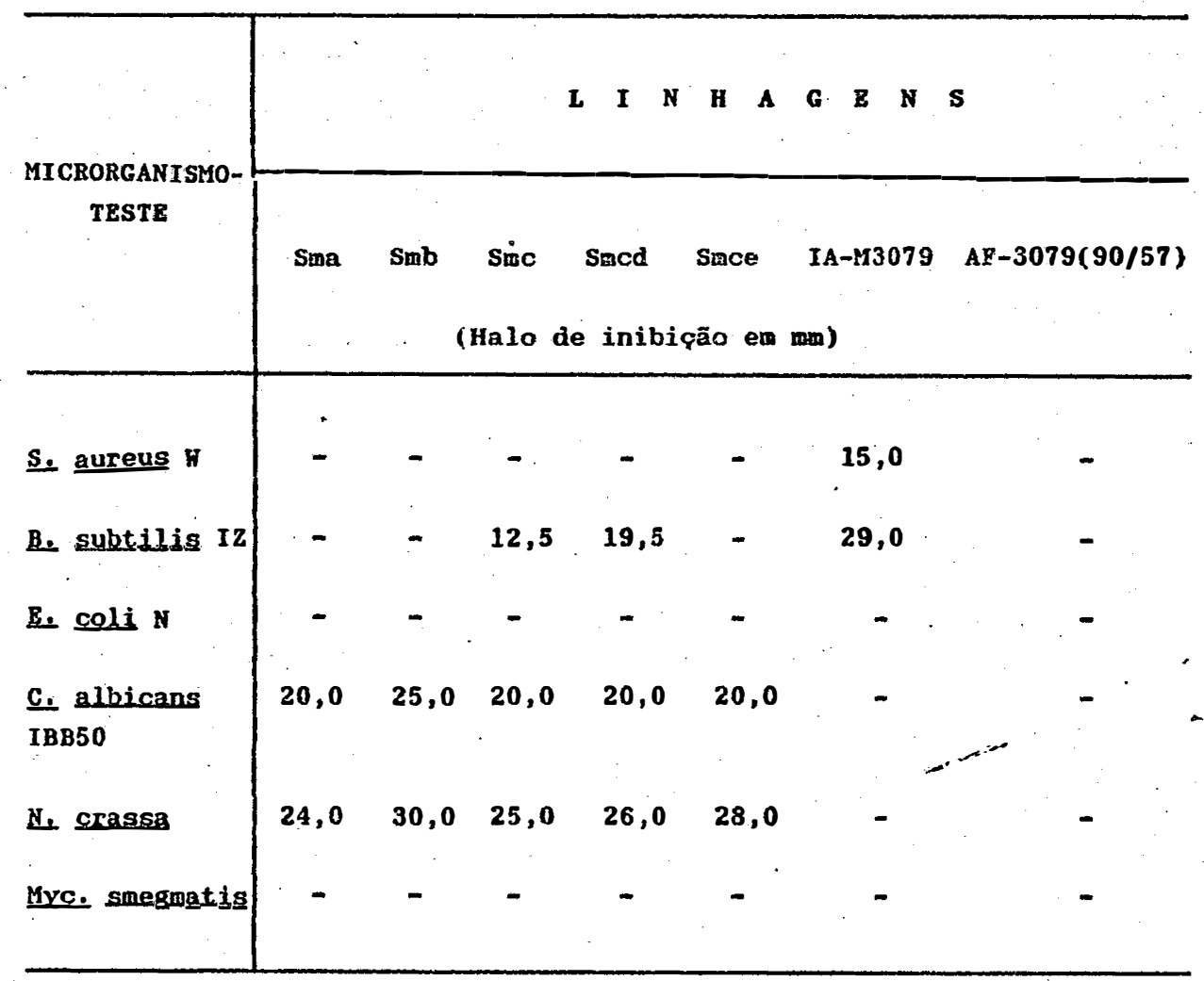

Obs.: Média de três repetições 
Nas Figuras 15 e 16 são mostrados os halos de inibição dos setores e dos parentais para Neurospora crassa e candida albicans IBB50.

Estes resultados indicam que a fusão de

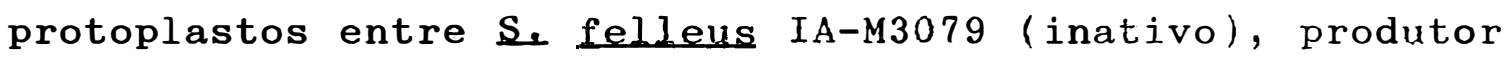
de actinomicina, e AF-3079(90/57) (viável), não produtor de actinomicina, promoveu a formação de setores recombinantes com capaeidade para a produção de um antifúngico.

Similarmente, OGURA et alii (1986) observaram que a variante EB-32 de se hroroscopicus 358AV2, produtor de carriomicina, passou a produzir um outro antibiótico após o tratamento com brometo de etídio. A variante ED32 produziu curromicina A e B, com estrutura química diferente de carriomicina, sugerindo aqueles autores que agente intercalante pode induzir o aparecimento de sequências repetidas de DNA, que influencia a produção de antibióticos pela ativação de genes silenciosos. A ativação de "genes silenciosos" foi demonstrada por JONES \& HOPWOOD (1984), através da clonagem molecular de plasmídio recombinante contendo gene estrutural da fenoxazinona sintetase (PHS 1,8 e PHS 4,3) de Sh antibietisus , produtor de actinomicina. A transformação de s. Lixidans $T K 24$ (não produtor da actinomicinas) pelos plasmídios recombinantes PHS 1,8 e PHS 4,3 resultou em clones com elevada atividade fenoxazinona sintetase, demonstrando, assim, que estes. 
plasmídios interagem com o DNA de S. Lividans, ativando genes normalmente silenciosos nesta linhagem. Segundo aqueles autores, o mecanismo de ativação do gene ainda não é conhecido, entretanto uma explicação seria que aqueles plasmídios recombinantes funcionam como um operador, o qual se liga ao repressor responsável pelo "gene silencioso" da fenoxazinona sintetase em S. Lividans.

Os resultados obtidos neste trabalho encontram apoio nestes argumentos da literatura quando se recorda que o mutante $A F 3079(90 / 57)$, não produtor de actinomicina, foi obtido pelo tratamento com acriflavina, que pode induzir perda de plasmídio e/ou mutação.

A fusão de protoplastos com a .línhagem selvagem produtora de actinomicina, provavelmente possibilitou a recombinação entre genes estruturais e regulatórios, passando a expressar uma via biossintética reprimida.

Com base na análise das características bioquímicas dos setores em que a utilização de manitol originou-se do parental "doador" (IA-M3079), associada à perda da produção de actinomicina, à sensibilidade a este antibiótico e, ainda, em decorrência da exigência nutricional para adenina, todos estes dados oferecem evidências da variação genética obtida pela recombinação cromossomal. O surgimento de variantes genéticas com 
habilidade para ${ }^{*}$ produção de outro antibiótico, possivelmente decorre, como enfatiza HOPWOOD (1981a), da inativação de genes regulatórios e expressão de vias biossintéticas normalmente reprimidas ocasionando o surgimento de outros antibióticos pela revelação de produtos de "genes silenciosos".

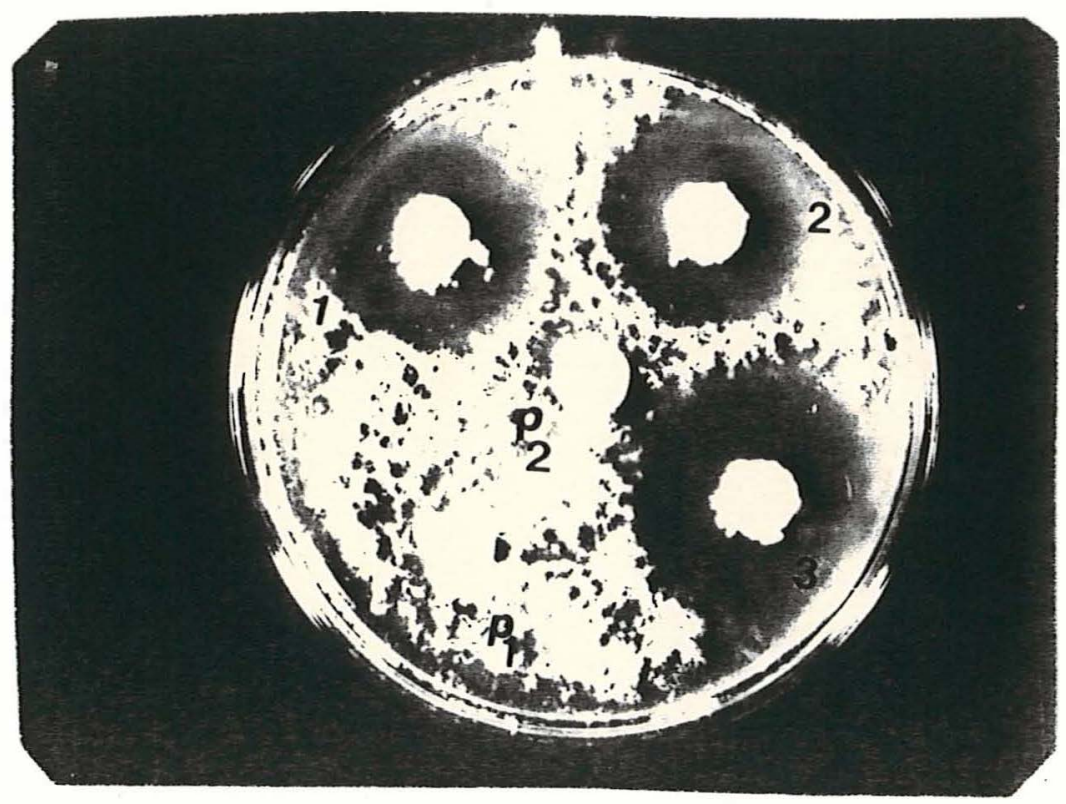

Figura 15. Halo de inibição do líquido fermentado com 96 horas de cultivo dos setores Sma, Smb e Smcd e dos parentais para Neurospora crassa: $P_{1}: S_{\text {. }}$ felleus; $\mathrm{P}_{2}: \mathrm{AF}-3079(90 / 57) ; 1: \mathrm{Sma} ; 2: \mathrm{Smb} ; 3$ : 


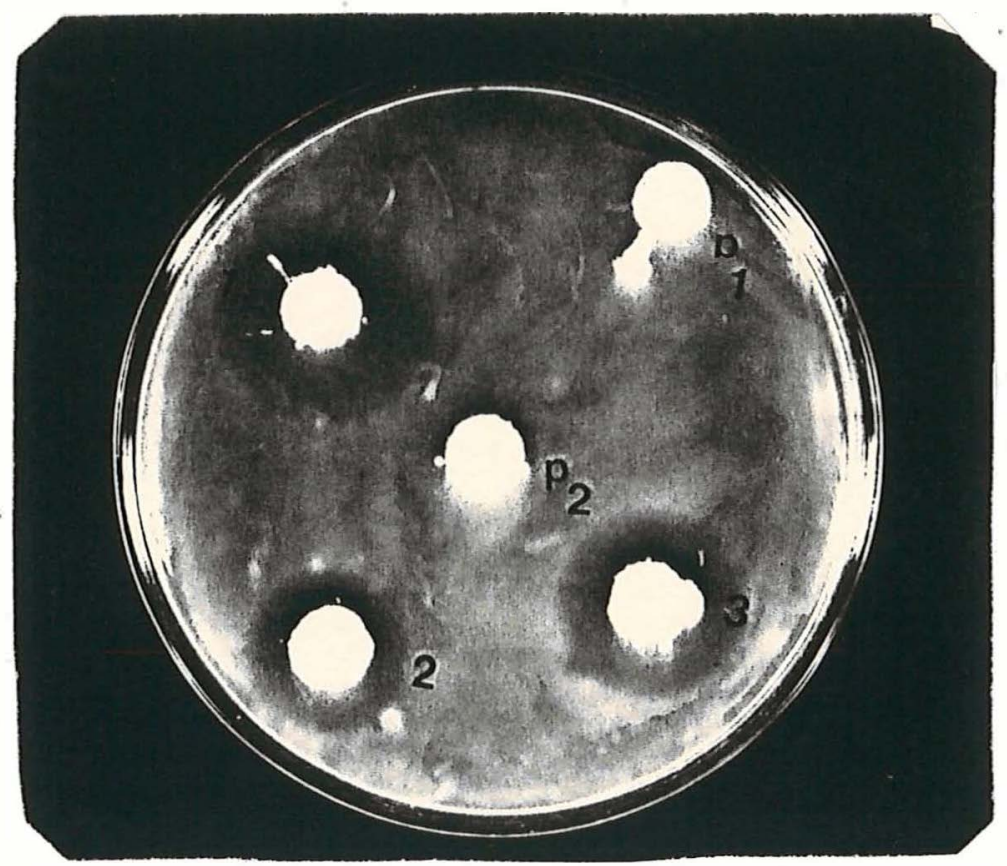

Figura 16. Halo de inibição do líquido fermentado com 96 horas de cultivo dos setores Sma, Smb e Smcd e dos parentais para candida albicans: $P_{1}: S_{\text {. }}$ felleus; $P_{2}: A F-3079(90 / 57) ; 1:$ Sma; 2: Smb; 3 : Smc 
4.7.1. Caraçterização do antifúngico

O antifúngico produzido pelo setor Sma no caldo fermentado apresentava atividade para c. albicans IBB50 de $10.000 \mathrm{U} / \mathrm{ml}$.

o extrato de acetato de etila foi purificado em coluna cromatográfica e das seis frações recolhidas, apenas três apresentaram halo de inibição em torno de $20 \mathrm{~mm}$ para c. albicans IBB50. Uma fração, de cor amarela palha solúvel em metanol, foi caracterizada através do espectro ultravioleta como não pertencente ao grupo dos antibió ticos poliênicos e, através da determinação da concentração mínima inibitória (CMI), foi verificada elevada atividade antimicrobiana de 0,05 a $0,1 \mathrm{mcg} / \mathrm{ml}$ para $\mathrm{C}$ albicans IBB50. Esta atividade antifúngica aprésentada pelos setores recombinantes possivelmente revela a recombinação entre genes estruturais e regulatórios. 
5. CONCLUSOES

Os resultados obtidos neste trabalho permitem as seguintes conclusões:

1. Streptomvces felleus IA-M3079, Streptomvces regensis IA-M3053 e Streptomyces parvulus IA-M3042 apresentaram grande instabilidade fenotípica após o tratamento com a acriflavina como agente intercalante.

2. A acriflavina alterou a produção de actinomicińa e a formação de pigmento amarelo nas linhagens estudadas.

3. As variantes não produtoras de actinomicina (act ${ }^{-}$) de Streptomyces felleus IA-M3079 e de Streptomyces regensis IA-M3053 mostraram-se estáveis na formação de micélio aéreo e ausência de pigmento solúvel.

4. Foi observada a presença de plasmídios conjugativos por fenótipo "pock" em Streptomyces felleus IA-M3079, Streptomyces regensis IA-M3053 e Streptomrces parvulus IA-M3042 e também nos setores recombinantes, após cruzamento com Streptomyces Iividans TK24. 
5. Os setores recombinantes obtidos por fusão de protoplastos intraespecífica do Streptomyces felleus IA-M3079 act $^{+} \mathrm{e}$ suas variantes act $^{-}$não mostraram transferência de pigmento amarelo ou produção de actinomicina.

6. Estes setores recombinantes, assim obtidos, apresentaram ação antimicrobiana para candida albicans IBB50 e exigência nutricional para adenina.

7. O antifúngico produzido por estes setores recombinantes não pertence ao grupo dos antibióticos poliênicos, uma vez que apresenta apenas dois picos máximos no espectro ultravioleta, 222 e $323 \mathrm{m \mu}$. 


\section{REFERENCIAS BIBLIOGRAFICAS}

AGUILAR, A. \& HOPWOOD, D.A. Determination of methylenomycin A synthesis by the pSVI plasmid from streptomyces violaceus-ruber SANK 95570. Journal of General Microbiology, London, 128: 1893-1901, 1982 .

AKAGAWA, H.; OKANISHI, M.; UMEZAWA, H. Genetic and biochemical studies of chloramphenicol-non-producing mutants of Streptomrces venezuelae carrying plasmid. Journal of Antibiotics, Tokyo, 32: $610=620,1979$.

$\rightarrow$ ANTONOV, P.P.; IVANOV, J.G.; MARKOV, G.G. Heterogeneity of Streptomyces DNA. EEBS Letters, 79: 151-4, 1977 .

ANZAI, H; MURAKAMI, T.; IMAI, S.; SATOH, A.; NAGAOKA, K.; THOMPSON, C. J. Transcriptional regulation of bialophos biosynthesis in Streptomyces hygroscopicus. Journal of Bacteriology, Baltimore, 169: 3482-3488, 1987 . 
ARAUJO, J.M.; RAMALHO DE MELLO, B.; FALCAO DE MORAIS, J.O.; SILVA, E.C.; MORAIS E SOUZA, M.A.; KURYLOWICZ, W. Fusão de protoplastos de streptomyces capoamus visando a obtenção de cepas produtoras de antibióticos "híbridos". Revista do Instituto de Antibiótices, Recife, 22(1/2): $53-64,1984 / 85$.

ASTOLFI, FILHO, S.; ZAHA, A.; FERREIRA, H.B.; MARCELINO, L.H. Introdução tecnologia do DNA recombinante. 2o Curso de Fundamentos de Biotecnologia, ESALQ/USP, PiracicabaSP. $1986.30 \mathrm{p}$.

AZEVEDO, J.L. \& COSTA, S.O.P. Exercícios Práticos de Genética, Ed. São Paulo, Companhia Editora Nacional, EDUSP, 1973. 288p.

BAITZ, R.H. Genetic recombination in Streptomyces fradiae by protoplast fusion and cell regeneration. Journal of Seneral Microbiology, London, 107: 93-102, 1978.

BAITY, N.H. Genetic recombination by protoplast fusion in St.reptounces. Developments in Industrial Microbielogy, :1: $43-54,1980$. 
BALTZ, R.H. Genetic and biochemistry of tylosin production: A model for genetic engineering in antibiotic-producing Streptomyces. In HOLLAENDER, A.; DEMOSS, R.D.; KAPLAN, S.; KONISKI, J; SAVAGE, D. WOLFE, R.S. ed. Genetic Engineering of Microorganisms for Chemicals, London, Plenum Press, 1982. p.431-444.

BALTŹ, R.H. Mutation in Streptomyces, In: QUEENER, S.W. \& DAY, L.E. ed. Antibiotic producing Streptomvces, London, Academic Press, 1986. p.61-94.

BALTZ, R.H. \& MATSUSHIMA, P. Protoplast fusion in Streptomyces: conditions for efficient genetic recombination and cell regeneration. Journal of General Microbiology, London, 127: 137-146, 1981 .

-, BECKER, B.; LECHEVALIER, M.P.; GORDON, R.E.; LECHEVALIER, H.A. Rapid differentiation between Nocardia and Streptomyces by paper chromatography of whole-cell hydrolysates. Applied Microbjelogy, Baltimore, 12: 421423,1964 . 
BENIGNI, R.; ANTONOV, P.P.; CARERE, A. Estimate of the genome size by renaturation studies in streptomyces. Applied Microbiology, Baltimore, 30: 324-326, 1975 .

BIBB, M.J. Genetic and physical studies of a Streptomyces coelicolor plasmid. PhD Thesis: University of East Anglia, Norwich, 1978 .

BIBB, M.J. \& HOPWOOD, D.A. Genetic studies of the fertility plasmid and its SCP2* variants in S, co으루요을 A3(2). Journal of General Microbiology, London, 126: 427-42, 1981 .

BIBB, M.J.; PREMAN, R.F.; HOPWOOD, D.A. Physical and genetical characterization of a second sex-factor. SCP2, for Streptomvces coelicolor A3(2). Molecular \& General Genetics, Berlin, 154: 155-156, 1977 .

BIBB, M.J.; SCHOTTEL, J.L.; COHEN, S.N. A DNA cloning system for interspecies gene transfer in antibioticproducing Streptomyces. Nature, London, 284: 526-531, 1980 . 
BIBB, M.J.; WARD, J.M.; HOPWOOD, D.A. Transformation of plasmid DNA into streptomycetes at high frequency. Nature, London, 274: 398-400, 1978 .

BIBB, M.J.; WARD, J.M.; KIEȘER, T.; COHEN, S.N.; HOPWOOD, D.A. Excision of chromosomal DNA sequencés from Streptomyces coelicolor forms a novel family of plasmid detectable in Streptomyces lividans. Molecular \& General Genetics, Berlin, 184: 230-240, 1981a.

- BUCHANAN, R.E. Studies on the nomenclature and classification of the bacteria; II. The primary subdivision of the Schizomycetes. Journal of Bacteriology, Baltimore, 2: 155-64, 1917 .

CHANG, S. \& COHEN, S.N. High-frequency transformation of Bacillus subtilis protoplasts by plasmid DNA. Molecular \& General Genetics, Berlin, 168: $111-115,1979$.

CHATER, K.F. \& BRUTON, C.J. Resistance, regulatory and production genes for the antibiotic methylenomycin are clustered. EMBO Journal. Oxford 4: 1893-1898, 1985. 
CHATER, K.F. \& HOPWOOD, D.A. Streptomyces genetics. In: GOODFELLOW, M.; MODARSKI, M. \& WILLIAMS, S.T., ed. The Biology of the Actinomycetes. London, Academic Press, 1983. p.229-286.

COX, K.L.; FISHMAN, S.E.; LARSON, J.L.; STANZAR, R. ; REYNOLDS, P.A.; YEH, W.K.; VAN FRANK, R.M.; BIRMINGHAM, V.S.; HERSHBERGER, C.L.; SENO, E.T. The use of recombinant DNA techniques to study tylosin biosynthesis and resistance in Streptomyces fradiae. Natural Products (Llovdia), 49: 971-980, 1986.

CRAMERI, R.; DAVIES, J.E.; H TTER, R. Plasmid curing and generation of mutations induced with ethidium bromide in streptomycetes. Journal of General Microbiology, London, 132: 819-824, 1986 .

CULLUM, J.; ALTENBUCHNER, J.; FLETT, F.; PIENDL, W. DNA amplification and genetic instability in Streptomyces. Biotechnology and Genetic Engineering Reviews, 4: 59-78, 1986 . 
DANIEL, D. \& TIRABY, G. A survey of plasmids among natural isolates of Streptomyces. The Jounnal of Antibiotics, Tokyo, $\underline{36}(2): 181-183,1983$.

DAUM, S.J. \& LEMKE, J.R. Mutational biosynthesis of new antibiotics. Annual Review Microbiological, Baltimore, 33: 241-265, 1979 .

DIETZ, A. Structure and taxonomy of streptomyces. In: QUEENER, S.W. \& DAY, L.E., ed. Antibiotic-producing Streptomyces. London, Academic Press, 1986. p. 1-25.

DISTLER, J.; BRAUN, C.; EBERT, A.; PIEPERSBERG, W. Gene cluster for streptomycin biosynthesis in streptomyces griseus. Analysis of essential regions including the major resistance gene. Molecular General Genetics. Berlim, 208: 204-210, 1987 .

DYSON, P. \& SCHREMPF, H. Genetic instability and DNA amplification in Streptomvces lividans 66. Journal of Bacteriology, Baltimore, 169: 4796-4803, 1987 . 
FERENCZI, L. Microbial protoplast fusion. In: S.W. GLOVER \& HOPWOOD, D.A. ed. Genetics as a tool in Microbiology. London, Cambridge University Press, 1981. p. 1-34.

FERENCKZY, L.; ZSOLT, J.; KEVEI, F. Forced heterokaryon formation in auxotrophic Geotrichum strains by protoplast fusion. In Third International Protoplast Symposium on Yeast Protoplast, p. 74. October 2-5. 1972. Salamanca. Spain: Abstracts.

FODOR, K. \& ASFOLDI, L. Fusion of protoplasts of Bacillus megaterium. Proceedings of the National Academy of Sciences, USA, 73: 2147-50, 1976 .

FODOR, K.; DEMIRI, E.; ASFOLDI, L. Polyethylene glycolinduced fusion of heat-inactivated and living protoplasts of Bacillus megaterium. Journal of Bacteriology, Baltimore, 135: 68-70, 1978 .

FRIEND, E.J.; WARREN, M.; HOPWOOD, D.A. Genetic evidence for a plasmid controlling fertility in an industrial strain of Streptomyces rimosus, Journal of General Microbielegy, London, 106: 201-206, $197 \dot{8}$. 
FRIGO, S.M. Variabilidade e fusão de protoplastos em Metarrhizium anisopliae (Metsch) Sorokin. Piracicaba, 1983. 119 p. (Tese-doutorado - Escola Superior de Agricultura "Luiz de Queiroz"/USP).

FRONTALLI, G.; HILL, L.R.; SILVESTRI, L.G. The base composition of deoxyribonucleic acid of Streptomyces. Journal of General Microbiology. London, 38: 243-50, 1965 .

FURUMAI, T.; TAKEDA, K. \& OKANISHI, M. Function of plasmids in the production of aureothricin. I. Elimination of plasmid and alteration of phenotypes caused by protoplast regeneration in streptomyces kasugaensis. Journal Antibiotics, Tokyo, 35: 1367-1373, 1982 .

GENTHNER, F.J.; HOOK, L.A. \& STROHL, W.R. Determination of the molecular mars of bacterial genomic DNA and plasmid copy number by high pressure liquid chromatography . Applied \& Environmental Microbiology, 50: 1007-1013, 1985 . 
GLADEK, A. \& ZAKRZEWSKA, J. Genome size of Streptomrces. EEMS Microbiology Letters, 24: 73-76, 1984 .

GORST-ALLMAN, C.; RUDD, B.A.M.; CHANG, C. \& FROSS, H.G. Biosynthesis of actinorrhodin. Determination of the point of dimerization. I. Organic Chemistry. 46 : 455456,1981 .

GUILLEN, N.; LE HEGARAT, F.; FLEURY, A.M.; HIRSCHBEIN, L. Folded chromosomes of vegetative Bacillus subtilis: composition and properties. Nucleic Acids Research, 5: $475-489,1978$.

HACKMANN, C. Action of actinomycin in experimental tumors. In: WAKSMAN, S., ed. Antinomycin, John Wiley \& Sons. N.Y. 1968, p.123-136.

HAESE, A. \& KELLER, U. Genetics of actinomycin C production in Streptomyces chrysomallus. Journal of Bacteriology, Baltimore, 170: 1360-1368, 1988 .

HIROCHIKA, H.; NAKAMURA, K.; SAKAGUCHI, K.A. Linear DNA plasmid from Streptomyces rochei with an inverted 
terminal repetition of 614 base pairs. EMBQ Journal, Oxford: $761-766,1984$.

HOOLEY, P. \& WELLINGTON, A.M.H. Formation and regeneration of protoplasts of Streptomyces hygrescopicus. Letters in Applied Microbiology, London, 1: 77-80, 1985 .

HOPWOOD, D.A. Genetic recombination in streptomyces 드이도이요. Journal of General Microbiology, London, 16(1): ii-iii, 1957 .

HOPWOOD, D.A. Linkage and the mechanism of recombination in Streptomyces coelicolor. Annals of the New York Academi of Sciences, New York, 81: 887-98, 1959 .

HOPWOOD, D.A. Genetic analysis and genome structure in Streptomyces coelicolor. Bacteriological Reviews, Baltimore, 31(4): 373-403, 1967 .

HOPWOOD, D.A. Extrachromosomally determined antibiotic $\rightarrow$ production. Annual Review of Mierobiol ogr, Palo Alto, 32: 373-392, 1978 . 
HOPWOOD, D.A. Genetic studies of antibiotics and other secondary metabolites. In GLOVER, S.W. \& HOPWOOD, D.A. ed., Genetics as a tool in Microbiology. Cambridge University Press. London, 1981a.p. 187-218.

HOPWOOD, D.A. Genetic studies with bacterial protoplasts. Annual Review of Microbielogy, Palo Alto, 35: 237-272, $\rightarrow$ $1981 \mathrm{~b}$.

HOPWOOD, D.A. Possible applications of genetic recombination in the discovery of new antibiotics in actinomycetes. In: NINET, L.; BOST, P.E.; BOUANCHAUD, D.H.; FLORENT, J., ed. The Future of Antibiotherapy and Antibiotic Research. London, Academic Press, 1981a. p. 407-416.

HOPWOOD, D.A.; BIBB, M.J.; BRUTON, C.J.; CHATER, K.F.; FEITELSON, J.S.; GIL, J.A. Cloning Streptomvces genes C) for antibiotic production. Trends in Biotechnology, 1: $42-48,1983$.

HOPWOOD, D.A.; BIBB, M.J.; CHATER, .F.; KIESER, T.; GRUTON, C.J.; KIESER, H.M.; LYDIATE, D.J.; SMITH, C.P.; WARD, 
J.M.; SCHIREMPE, H. Genetic Manipulation of streptamyces a Laboratory Manual. John Innes Institute, $1985 a$. Norwich.

HOPWOOD, D.A. \& CHATER, K.F. Streptomycetes. In BALL, C. Genetics and Breeding of Industrial Microorganisms. Florida, CRC Press. 1984. p. 7-42.

HOPWOOD, D.A.; CHATER, K.F.; DOWDING, J.E.; VIVAN, A. Recent advances in streptomvces coelicolor genetics. Bacteriological Reviews, Baltimore, 37: 371-405, 1973 .

HOPWOOD, D.A. \& GLAUERT, A.M. The fine structure of Streptomyces coelicolor. II The nuclear material. Journal Biophysical Biochemical Cytology 3 : 267-278, 1960 .

HOPWOOD, D.A.; HINTERMANN, G.; KIESER, T.; WRIGHT, H.M. Integrated DNA sequences in. three streptomycetes form related autonomous plasmids after transfer to Streptomyces lividans. Plasmid, New York, 11: 1-16, $1984 a$. 
HOPWOOD, D.A.; KIESER, T.; LYDIATE, D.J.; BIBE, M.J. Streptomyces plasmids: their biology and use as cloning vectors. In: QUEENER, S.W. \& DAY, L.E., ed. Antibioticproducing Streptomyces. London, Academic Press, 1986. p.159-230.

HOPWOOD, D.A.; KIESER, T.; WRIGHT, H.M.; BIBB, M.J. Píasmids, recombination and chromosome mapping in Streptomyces lividans 66. Journal of General Microbiology, London, 129: 2257-2269, 1983a.

HOPWOOD, D.A.; LYDIATE, D.J.; MALPARTIDA, F.; WRIGHT, H.M. Conjugative sex plasmids of Streptomvces. In: HELINSKI, D.; COHEN, S.N.; CLEWELL, D.B.; JACKSON, D.A.; HOLANDER, A., ed. Plasmid in Bacteria. New York, Plenum Press, 1984 . p.615-634 .

HOPWOOD, D.A.; MALPARTIDA, F.; KIESER, H.M.; IKEDA, H.; DUNCAN, J.; FUJII, I.; RUDD, B.A.; FLOSS, H.G.; OMURA, S. Production of "hybrid" antibiotics by genetic engineering. Nature, London, 314: 642-644, 1985b. 
HOPWOOD, D.A. \& MERRICK, M.J. Genetics of antibiotic production. Bacteriolegical Reviews, Baltimore, $41(3)$ : $595-635, .1977$.

HOPWOOD, D.A. \& SERMONTI, G. The genetics of Streptomyces coelicolor. Advances in Genetics, 11: 273-342, 1962.

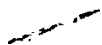

HOPWOOD, D.A.; THOMPSON; C.J.; KIESER, T.; WARD, J.M. \& WRIGHT, H.M. Progréss in the development of: plasmid cloning vectọns for streptomyces. In: SCHLESSIGER, D. ed., "Microbiology-1981". American Society Microbiology. Washington. 1981. p. 376-379.

HOPWOOD, D.A. \& WRIGHT, H.M. Bacterial protoplast fusion: recombination in fused protoplasts of Streptomyces coelicolor. Molecular \& General Genetic, Berlin, 162: $307-317,1978$.

HOPWOOD, D.A. \& WRIGHT, H.M. Factors affecting recombinant frequency in protoplast fusion of streptomvces coelicolor. Journal of General Microbiology London, 11: $137-143,1979$. 
HOPWOOD, D.A. \& WRIGHT, H.M. Protoplast fusion in Streptomyces fusions involving ultraviolet-irradiated protoplasts. Journal of General Microbiology, London, 126: $21-27,1981$.

HOPWOOD, D.A.; WRIGHT, H.M.; BIBB, M.J.; COHEN, S.N. Genetic recombination through protoplast fusion in streptomyces. Nature, London, 268: 171-174, 1977.

HOTTA, K.; YAMASHITA, F.; OKAMI, Y. \& UMEZAWA, H. New antibiotic-producing streptomycetes selected by $\rightarrow$ antibiotic resistance as a marker. II. Features of a new antibiotic-producing clone obtained after fusion treatment. The Journal of Antibiotics, Tokyo, 38: 64-69, 1985 .

HRANUELI, D.; PIGAC, J.; SMOKVINA, T.; ALACEVIC, M. Genetic interactions in streptomyces rimosus mediated by conjugation and by protoplast fusion. Journal of General Microbiology, London, 129: 1415-1422, 1983. 
HÜTTER, R. \& ECKHARDT, T. Genetic manipulation. In: M. GOODFELLOOW, ed. Actinomycetes in Biotechnology. London. Academic Press, 1988. p.89-184.

ICHIKAWA, T.; ISHIKURA, T.; OZAKI, A. Improvement of kasugamycin-producing strain by the agar piece method and the prototroph method. Folia Microbiol. 16: 218224,1971 .

IKEDA, H.; INOUE, M.; OMURA, S. Improvement of macrolide antibiotic-producing streptomycete strains by the regeneration of protoplasts. The Iournal of Antibiotics; Tokyo, 36(3): 283-288, 1983 .

IKEDA, H.; TANAKA, H.; OMURA, S. Genetic and biochemical features of spiramycin biosynthesis in streptomyces ambofaciens. Curing, protoplast regeneration and plasmid transfer. The Journal of Antibiotics, Tokyo, 35(4): 507516,1982 .

JACOBSON, E.; GRANVILLE, W.C.; FOSS, C.E. Color Harmony Manual, 3rd ed. Container Corp. of America, Chicago, 1948. JONES, G.H. \& HOPWOOD, D.A. Activation of 
phenoxazinone synthase expression in Streptomyces lividans by cloned DNA sequences from Streptomyces antibioticus. The Journal of Biological chemistry, 259(22): $14158-14164,1984$.

JONES, G.H. \& HOPWOOD, D.A. Activation of phenoxazinone synthase expression in Streptomyces lividans by cloned DNA sequences from streptomyces antibioticus. The Journal of Biological Chemistry 259(22): 14158-14164, 1984 .

KADO, C.I. \& LIU, S.T. Rapid procedure for detection and isolation of large and small plasmids. Journal of Bacterielegy, Baltimore, 145 (3): 1365-1373, 1981.

KAO, K.N. \& MICHAYLUK, M.R. A method for high-frequency intergeneric fusion of plant protoplasts: 2lanta, 115: $355-367,1974$.

KATZ, E. Actinomycin. In: GOTTLIEB, D. \& SHAWED, P.D.B Antibiotics II. New York. Springer-Verlag. 1967. p.276341 . 
KATZ, E. \& WEISSBACH, H. Biosynthesis of the actinomycin chromophore; enzymatic conversion of 4-methyl-3hydroxyantranilic acid to actinocin. The Journal of Biological Chemistry, 237(3): 882-886, 1962 .

KERSTERS, K. \& DE LEY, J. Identification and grouping of bacteria by numerical analysis of their electrophoretic protein patterns. Journal of General Microbielogy, London, 87: 333-342, 1975 .

KIESER, T. Factors affecting the isolation of CCC DNA from Streptomvces lividans and Escherichia coli. Plasmid, New York, 12: 19-36, 1984 .

KIESER, T.; HOPWOOD, D.A. ; WRIGHT, H.M.; THMPSON, C.J. pIJ101, a multi-copy broad host-range streptomyces plasmid: functional analysis and development of DNA cloning vectors. Melecular \& General Genetics, Berlin, 185: $223-38,1982$.

KINASHI, H. \& SHIMAJI, M. Detection of giant linear plasmids in antibiotic producing strains of Streptomvces 
by the OFAGE technique. The Journal of Antibiotics, Tokyo, 40(6): 913-6, 1987 .

KINASHI, H.; SHIMASI, M.; SAKAI, A. Giant linear plasmids in streptomyces which code for anibiotic biosynthesis genes. Nature, London, 328: 454-456, 1987 .

KIRBY, R. \& HOPWOOD, D.A. Genetic determination of methylenomycin biosynthesis by the SCP1 plasmid of Streptomyces coelicolor A3 (2). Journal ef General. Microbiology, London, 98: 239-252, 1977 .

KOBAYASHI, T.; SHIMOTSU, H.; HORINOUCHI, S. ; VOGUMI, T.; BEPPU, T. Isolation and characterization of a pockforming plasmid pTA4001 from streptomyces lavendulae. The Lournal of Antibiotics, Tokyo, 37: 368-75, 1984.

KOJIMA, I. ; NANJYO, T. \& OKANISHI, M. Mutual relation of three pock-forming plasmids, resident in streptomyces noursei. The Journal of Antibiotics, Tokyo, 38(3): 390400,1985 . 
KRETSCHMER, S. \& KUMMER, C. Increase of nucleoid size with increasing age of hyphal region in vegetative mycelia of Streptomices granaticolor. Journal of Basic Microbiology, 27: 23-7, 1987 .

KURYLOWICZ, W.; KURZATKOWSKI, W.; SOLECKA, J . Improvement of industrially important streptomycetes by protoplast fúsion and regeneration. In: DA SILVA, E.J.; DOMMERGHES, Y.R.; NYNS, E.J.; RATLEDGE, C. Microbial Technology in the Developing World. Oxford University Press, 1987 p. 185-195 .

KURYLOWICZ, W.; PASZKKIEWICZ, A.; KURZATOWSKI, W.; SZULGA, T. Numerical taxonomy of streptomycetes (ISP strains). In: ARAI, T., ed. Actinomvcetes; The Boundary Microorganisms. Tokyo, Toppan Company, 1976. p.323-40.

KÜSTER, E. Outline of a comparative study of criteria used in characterization of the actinomycetes. International Bulletin Bacterial Nomenclature and Taxonomia 2: 98-104, 1959 . 
KüSTER, E. Simple working key for the classification and identification of named taxa included in the - International Streptomyces Project. International Journal of Systematic Bacteriolegy, Washington, 22: 13948,1972 .

LAEMMLI, V.K. Cleavage of structural proteins during the assembly of the head of bacteriophage TH. Nature, London, 227: 681-685, 1970 .

LECHEVALIER, H.A. \& LECHEVALIER, M.P. Chemical composition as a criterion in the classification of aerobic actinomycetes. International Journal Systematic Bacterielegy, Washington, 20: 435, 1979 .

MALPARTIDA, F. \& HOPWOOD, D.A. Molecular cloning of the whole biosynthetic pathway of a streptomyces antibiotic and its expression in a heterologous host. Nature, London, 309: 462-464, 1984 .

MALPARTIDA, F. \& HOPWOOD, D.A. Physical and genetic characterization of the gene cluster for the antibiotic 
actinorhodin in Streptomyces coelicolor A3(2). Molecular \& General Genetics, Berlin, 205: 66-73, 1986 .

MALPARTIDA, F.; ZALACAIN, N.; JIMENEZ, A.; DAVIES, J. Molecular cloning and expression in streptomyces lividans of a hygromycin B phosphottransferase gene from Streptomyces hygroscopicus. Biochemical and Biophysical Reseárch Communications, 117: 6-12, 1983 .

MERRICK, M.J. A morphological and genetic mapping study of bald colony mutants of Streptomyces coelicolor. Journal General Microbiology, London, 96: 299-315, 1976.

MURAKAMI, T.; ANZAI, H.; IMAI, S.; SATOH, A.; NAGAOKA, K.; THOMPSON, C.J. The bialaphos biosynthetic genes of Streptomyces hygroscopicus; Molecular cloning and characterization of the gene cluster. Molecular \& General Genetics, Berlin, 205: 42-50, 1986.

MURAKAMI, T•; NOJIRI, C.; TOYAMA, H.; HAYASHI, E.; YAMADA, Y.; NAGAOKA, K. Pock forming plasmids from antibioticproducing Streptomyces. The Journal of Antibiotics, Tokyo, 36(4): 429-34, 1983 . 
MURRAY, R.G.E. - A place for bacteria in the living world. BUCHANAN, R.E.; GIBBONS, N.E.; COWAN, S.T.; HOLT, J.G.; MURRAY, R.G.E.; NIVEN, C.F.; RAVIN, A.W.; STANIER, R.Y., ed. In: Bergey's Manual of Determinative Bacteriology. Williams Wilkins, Baltimore, p.4-13, 1974 .

NONOMURA, H. Key classịfication and identification of 458 species of the streptomycetes included in ISP. Journal of Eermentation Technology, Osaka, 52: 78-92, 1974 .

NORMANSELL, I.D. Strain improvement in antibioticproducing microorganisms. Journal Chemical Technology Biotechnology, 32: 296-303, 1982 .

OCHI, K. Protoplast fusion permits high-frequency transfer of a Streptomyces determinant which mediates actinomycin synthesis. Journal Bacteriology, Baltimore, 150: 592597,1982 .

OCHI, K. \& KATZ, E. The possible involvement of a plasmid(s) in actinomycin synthesis by streptomyces parvulus and Streptomyces antibioticus. The Journal of Antibiotics, Tokyo, 31(11): 1143-1148, 1978 . 
OCHI, K. \& KATZ; E. Genetic analysis of the actinomycinproducing determinants (plasmid) in streptomrces parvulus using the protoplast fusion technique. Canadian Journal Microbiology, 26: 1460-1464, 1980 .

OGAWA, H.; IMAI, S.; SATOH, A.; KOJIMA, M. An improved method for the preparation of streptomycetes and Micromonospora protoplasts. The Iournal of Antibiotics, Tokyo, $\underline{36}(2): 184-186,1983$.

OGURA; M.; TANAKA, T.; FURIHATA, K.; SHIMAZU, A.; OTAKE, N. Induction of antibiotic production with ethidium bromide in Streptomyces hygroscopicus. The Journal of Antibiotics, Tokyo, $\underline{39}(10): 1443-1449,1986$.

OHNUKI, T.; IMANAKA, T.; AIBA, S. Self-cloning in Streptomyces griseus of an str gene cluster for streptomycin biosynthesis and streptomycin resistances. Journal Bacteriology, Baltimore, 164: 85-94, 1985 .

OKANISHI, M. Plasmids and antibiotic synthesis in streptomycetes. In: SEBEK, O.K. \& LASKIN, A.I., ed. Genetics of Industrial Microorganisms, Proceedings of 
the 3rd International Symposium GIM78. American Society for Microbiology, Washington DC, 1979. p.134-140.

OKANISHI, M. Plasmid involvement in antibiotics production. In: SAKAGUCHI, K. \& OKANISHI, M. ed. Molecular Breeding and Genetics of Applied Microorganisms. London, Academic Press, 1980. p.29-46. .

OKANISHI, M.; MAŃOME, T.; UMEZAWA, H. Isolation and characterization of plasmid DNAs in actinomycetes. The Journal of Antibiotics, 33: 88-91, 1980 .

OKANISHI, M.; OHTA, T.; UMEZAWA, H. Pośsible control of formation of aerial mycelium and antibiotic production in Streptomyces by episomic factors. The Journal of Antibiotics, Tokyo, 23: 45-47, 1970 .

OKANISHI, M.; SUZUKI, K.; UMEZAWA, H. Formation and reversion of streptomycete protoplasts: cultural condition and morphological study. Journal of General Microbiolegy, London, 80: 389-400, 1974 . 
OMURA, S.; IKEDA, H.; TANAKA, H. Extraction and characterization of plasmids from macrolide antibioticproducing streptomycetes. The Journal of Antibiotics, Tokyo, 34: 478-482, 1981 .

ONO, H.; HINTERMANN, G.; CRAMERI, R.; WALlis, G; HÜTTER, R. Reiterated DNA sequences in a mutant strain of Streptomyces glaucescens and cloning of the sequence in Escherichia coli. Molecular \& General Genetics Berlin, 186: $106-10,1982$.

PACCOLA-MEIRELLES, L.D.; VALARINI, M.J.; AZEVEDO, J.L.; ALFENAS, A.C. Manual de Técnicas Eletroforéticas em Microrganismos. ESALQ/FEALQ-Piracicaba. 1988. 54p.

PERNODET, J.L. \& GUERINEAU, M. Isolation and physical characterization of streptomycete plasmids. Molecular \& General Genetics, Berlin, 182: 53-59, 1981 .

POGELL, B.M. Regulation of aerial mycelium formation in streptomycetes. In: SEBEK, O.K. \& LASKIN, A.I. Genetics of Industrial Microorganisms. Washington. American Society for Microbiology 1979, p.218-224. 
PONTECORVO, G.; ROPER, J.A.; HEMMONS, L.M.; MCDONALD, K.D. ; BUFTON, A.W.J. The genetics of Aspergillus nidulans. Advances Genetic, 5: 141-238. 1953 .

PRAUSER, H. Aptness and application of colour codes for exact description of colours of streptomycetes. Zejtschrift Allg, Mikrobiologie, 4: 95-98, 1964 .

PRIDHAM, T.G.; ANDERSON, P.; FOLEY, C.; LINDENFELSER, L.A.; HESSELTINE, C.W.; BENEDICT, R.G. A selection of media for maintenance and taxonomic study of streptomycetes. Antibiotics Annual 1956/57, p.947-953.

PRIDHAM, T.G. \& GOTTLIEB, D. The utilization of carbon compounds by some Actinomvcetales as an aid for species determination. Journal Bacterielogy, Baltimore, 56: 107114. 1948 .

PRIDHAM, T.G.; HESSELTINE, C.W.; BENEDICT, R.G. A guide for the classification of streptomycetes according to selected groups: placement of strains in morphological section. Applied Microbiological, 6: 52-61, 1958 . 
PRIDHAM, T.G. \& TRESNER, H.D. Family VII. Streptomycetaceae Waksman and Henrici 1943. In: BUCHANAN, R.E. \& GIBBONS, N.E. ed. Bergey's Manual of Determinative Bacteriology, 8th ed. Williams and Wilkins, Baltimore, 1974.

QUEENER, S.W. \& BALTZ, H. Genetics of industrial microorganisms. In: PERLMAN, D. ed. Annual Reports on Fermentation Process. Academic Press, London, 1979. p. $5-45$.

QUEENER, S.W. \& DAY, L.E. In: Antibiotic: producing Streptomyces, London, Academic Press, 1986.

RAMOS, A.; VALIN, C.; JOSEPH, N.; VISOZO, A.; PEREZ, D.; ALONSO, E.; VILLANUEVA, S.; RODRIGUEZ, R. Enhancement of oxytetracycline production in a streptomyces rimosus strain after treatment with acriflavine. Biotechnology Letters, $8(3): 161-162,1986$.

REDShaW, P.A.; McCANN, PENTELla, M.A.; POGELl, B.M. Simultaneous loss of multiple diferentiated functions in aerial mycelium-negative isolates of streptomycetes. Iournal of Bacterielogy, Baltimore, 137: 891-899, 1979. 
RHODES, P.M.; HUNTER, I.S.; FRIEND, E.J . ; WARREN, M. Recombinant DNA methods for the oxytetracycline producer Streptomyces rimosus. Biochemical Society Transactions, $12: 586-588,1984$.

ROBINSON, M.; LEWIS, E.; NAPIER, E. Occurence of reiterated DNA sequences in strains of Streptomyces produced by an interspecific protoplast fusion. Molecular \& General Genetics, Berlin, 182: 336-340, 1981 .

SAGARA, Y•; FUKUI, K.; OTA, F.; YOSHIDA, N.; KASHIYAMA, T.; FUJIMOTO, M. Rapid formation of protoplasts of Streptomyces griseoflavus and their fine structure. Japanese Journal of Microbielogy, 15: 73-84, 1971.

SCHLEIFER, K.H. \& STACKEBRANDT, E. Molecular Systematics of prokaryotes. Annual Review Microbiological, Baltimore, 37: $143-187,1983$.

SCHREMPF, H. Plasmid loss and changes within the chromosomal DNA of Streptomyces reticuli. Journal of Bacteriology, Baltimore, 151(2): 701-707, 1982a. 
SCHREMPF, H. Role of plasmids in producers of macrolides. Journal of chemical Technology and Biotechnolegy, London, 32: 292-295, $1982 \mathrm{~b}$.

SCHREMPF, H. Deletion and amplification of DNA sequences in melanin-negative variants of Streptomyces reticuli. Molecular \& General Genetics, Berlin, 189: 501-505, $1983 \div$

SCHEREMPF, H. \& GOEBEL, W. Function of plasmid genes in Streptomyces reticuli. In: TIMMIS, K.N. \& PUHLER, A. ed. Plasmids of Medical Environmental and Commercial Importance. Elsevier, Amsterdan North Holland Biomedical Press, 1979. p.259-268.

SENO, E.T. \& HUTCHINSON, C.R. The biossinthesis of Tylosin and erytromycin: model system for studies of the genetics and biochemistry of antibiotic formation. In: QUEENER, S.W. \& DAY, L.E. ed. Antibiotics: producing Streptomyces. London, Academic Press, 1986. p.231-280.

SERMONTI, G. \& SPADA-SERMONTI, J. Genetic recombination in Streptomyces. Nature, London, 176: 121-1955. 
SHAW, C.R. \& PRASAD, R. Starch gel electrophoresis of enzymes a compilation of recipes. Biochem. Genetic, 4: $297-320,1970$.

SHAW, P.D. \& PIWOWARSKI, J. Effects of ethidium bromide and acriflavine on streptomycin production by Streptomyces bikiniensis. The Iournal of Antibiotics, 30: 404-408, 1977 .

SHIER, W.T.; RINEHART, K.L.Jr.; GOTTLIEB, D. Proceeding National Academia Society, USÁ, 63: 138-204, 1969.

SHINDOH, Y.; NAKANO, M.M.; OGAWARA, H. Pock-forming plasmids isolated from streptomvces roscochromogenus. The Journal Antibiotics, Tokyo, 37: 512-517, 1984.

SHINOBU, R. Physiological and cultural study for the identification of soil actinomyceté species. Mem. Osaka Univ. B. Nat. Sci. I: 1-76, 1958.

SHIRAHAMA, T.; FURUMAI, T.; OKANISHI, M. A modified regeneration method for streptomycete protoplasts. 
Agricultural and Biological Chemistry, 45(5): 1271-1273, 1981 .

SHIRLING, E.B. \& GOTTLIEB, D. Methods for characterization of Streptomyces species. International Journal of Systematic Bacteriology, Washington, 16(3): 313-340, 1966 .

SHIRLING, E.B. \& GOTTLIEB, D. Cooperative description of type cultures of Streptomyces: II. Species descriptions from first study. International Jounnal ef Systematic Bacteriology, Washington, 18: 69-189, 1968a.

SHIRLING, E.B. \& GOTTLIEB, D. Cooperative description of type cultures of Streptomyces; III. Additional species descriptions from first and second studies. International Iournal of Systematic Bacterielogy. Washington, 18: 279-399, 1968b.

SHIRLING, E.B. \& GOTTLIEB, D. Cooperative description of type cultures of Streptomyces; IV. Species descriptions from the second, third and fourth studies. International 
Journal of Systematic Bacteriology, Washington, 19: 391-. 512,1969 .

SHIRLING, E.B. \& GOTTLIEB, D. Cooperative description of type strain of Streptomyces: V. Additional descriptions. International Journal of Systematic Bacteriology. Washington, 22: 265-394, 1972 .

SHIRLING, E.B. \& GOTTLIEB, D. Retrospective evaluation of International Streptomyces Project taxonomic criteria. In: ARAI, T., ed. Actinomycetes; the boundary microorganisms, Tokyo, Toppan Company, 1976. p.9-41.

SINGER, C.E. \& AMES, B.N. Sunlight ultraviolet and bacterial DNA base ratios. Science, 170: 822-826, 1970 .

SKURRAY, R.A. \& REEVES, P. Characterization of lethal zygosis associated with conjugation in Escherichia coli K-12. Journal. of Bacteriology, Baltimore, 113: 58-70, 1973 . 
STACKEBRANDT, E. \& WOESE, C.E. Towards a phylogeny of the actinomycetes and related organisms. Current Microbiological, 32: 1-31, 1981 .

STANZAK, R.; MATSUSHIMA, P.; BALTZ, R.H.; RAO, R.N. Cloning and expression in Streptomyces lividans of clustered erytromycin biosynthesis genes from streptomyces. erythreus. Bio/Technology, 4: 222-232, 1986.

SZABO, J.M.; MARTON, M.; BUTI, J.; FERNANDEZ, C. A diagnostic key for the identification of "species" of Streptomyces and Streptoverticildium included in the International Streptomyces Project. Acta Botanical. Academic Science, Hungary, 21: 387-418, 1975.

TEWFICK, E.M. \& BRADLEY, S.G. Characterization of deoxyribonucleic acids from streptomycetes and nocardiae. Journal of Bacteriology Baltimore, 94: 19942000,1967 .

THOMPSON, C.J.; KIESER, T.; WARD, J.M.; HOPWOOD, D.A. Physical analysis of antibiotic resistance genes from 
Streptomyces and their use in vector construction. Gene, 20: 51-62, 1982a.

THOMPSON, C.J.; WARD, J.M.; HOPWOOD, D.A. DNA cloning in Streptomyces resistance genes from antibiotic-producing species. Nature, London, 286: 525-527, 1980.

THOMPSON, C.J.; WARD, J.M.; HOPWOOD, D.A. Cloning of antibiotic resistance and nutritional genes in streptomycetes. Journal of Bacteriology, Baltimore, $151(2): 668-677,1982 b$.

TOYAMA, H•; HAYASHI, E.; NOJIRI, C.; KATTSUMATA, K; MIYATA, A.; YAMADA, Y. Isolation and characterization of small plasmids from streptomyces. The Iournal of Antibiotics, Tokyo, 35: 369-73, 1982 .

TOHYAMA, H.; OKAMI, Y.; UMEZAWA, H. Nucleotide sequence of streptomycin phosphotransferase and amidinotransferase genes in a gene cluster cloned from streptomyces griseus. Nucleic Acids Research, 15: 1819-1833, 1987. 
TRESNER, H.D. \& DẠNGA, F. Hydrogen sulfide production by Streptomrces as a criterion for species differentiation. Journal Bacteriology, Baltimore, 76: 239-244, 1958.

USDIN, K•; CHRISTIANS, K.M.; DEWET, C.A.; POTGIETER, T.D.; SHAW, C.B.; KIRBY, R. The loss of a large DNA fragment is associated with an aerial mycelium negative (Amy-) phenotype, of Streptomyces cattleva. Journal of General Microbiology, London, 131: 979-981, 1985.

USDIN, K.; GERTSCH, K.; KIRBY, R. Evidence for the wide distribution of repetitive DNA sequences in the genus Streptomyces. Journal of Molecular Evolution. New 'Tork, 20: $25-30,1984$.

VIVIAN, A. Genetic control of fertility in streptomyces ㅌㅇ리도이요 A3(2): plasmid involvement in the interconversion of UF and IF strains. Journal ef General Microbiology, London, 69: 353-64, 1971.

VIVIAN, A. \& HOPWOOD, D.A. Genetic control of fertility in Streptomyces coelicolor A3(2): the IF fertility type. 
Journal of General Microbiology, London, 64: 101-17, 1970 .

WAKSMAN, S.A. The Actinomycetes. Vol. II. Classification, identification and descriptions of genera and species. Williams et Wilkins - Baltimore, 1961.

WAKSMAN, S.A. Actinomycin. Nature, Formation and Activities. Interscience Publishers, 1968. 231p.

WAKSMAN, S.A. \& CURTIS, R.E. The actinomyces of the soil. Soil Science, 1: 99-134, 1916.

WAKSMAN, S.A. \& HENRICI, A.T. The nomenclature and classification of the actinomycetes. Journal of Bacteriology, Baltimore, 46: 337-41, 1943 .

WAKSMAN, S.A. \& WOODRUFF, H.B. Actinemrees antibieticus a new soil organism antagonistic to pathogenic and nonpathogenic bacteria. Journal of Bacteriolegy, Baltimore, 42: 231-249, 1941 . 
WALLIN, A.; GLIMELI̦US, K.; ERIKSSON, T. The induction and aggregation and fusion of Daucus carota protoplasts by polyetilene glicol. Zeitschrift für Rflanzenphrsiologie, 74: 64-80, 1974 .

WESTPHELING, J. Physical studies of streptomyces plasmids. PhD Thesis. University of East Anglia, Norwich, 1980.

WHITNEY, P.J.; VAUGHAN, J.G \& HEALE, J.B. A disc electrophoretic study of the proteins of Verticillium abo-atrum, Verticillium dahliae and Fusarium oxysporum with reference to their taxonomy. Iournal ef Fxperimental Botany, 19: 415-426, 1968 .

WILLETS, N. \& SKURRAY, R. The conjugation system of F-like plasmids. Annual Review of Genetics, Palo Alto, 14: 41-. 76,1980 .

WIJLIAMS, S.T.; GOODFELLOW, M.; ALDERSON, G. Genus Streptomyces Waksman \& Henrici. In: WILLIAMS, S.; SHARPE, M.E.; HOLT, J.G., ed. Bergey's Manual of Systematic Bacteriology. Williams \& Wilkins, Baltimore, 1939. 
WILLIAMS, S.T.; GOODFELLOW, M.; ALDERSON, G.; WELLINGTON, . E.M.G.; SNEATH, P.H.A.; SAKIN, M.J. Numerical classification of streptomyces and related genera. Journal of General Microbiology, London, 129: 1743-813, 1983 .

WORCEL, A. \& BURGI, E. Properties of a membrane attached form of the folded chromosome of Escherichia celi. Journal Nolecular Biology, 82: 91-105, 1974.

WRIGHT, L.F. \& HOPWOOD, D.A. Actinorhodin is a chromasomally-determined antibiotic in streptomyces coeticelor A3(2). Journal, of General Microbiology, London, 96: 289-297, 1976a.

WRIGHT, L.F. \& HOPWOOD, D.A. Identification of the antibiotic determined by the $\mathrm{SCP}^{1}$ plasmid of Streptomyces coelicolor A3(2). Jounnal of General Microbielogy, London 95: 96-106, 1976b.

XUE, Y.; ZHU, Y.; ZHUANG, Z. \& TAN, H. Streptomyces griseus plasinid codes some genes involved in streptomycin biosynthesis. Acta Genetica Sinica, 8: 14-20, 1981. 
YAMAGUCHI, T. Comparison of cell wall composition of morphologically distinct actinomycetes. Iournal of Bacteriology, 89: 444-451, 1965 .

YAMASHITA, F.; HOTTA, K.; KURASAWA, S.; OKAMI, Y.; UMEZAWA; H. New antibiotic-producing streptomycetes, selected by antibiotic resistance as a marker. I. New antibiotic production generated by protoplast fusion treatment between Streptomyces griseus and S, tenjimariensis. The Journal of Antibiotics, Tokyo, 38(1): 58-63, 1985.

YOUXIA, Z.; XIAOXUE, X.; TINLAN, Z. A new compound generated from interspecific protoplast fusion in Streptomycetes. "Fifth International Symposium on the Genetics of Industrial Microorganisms". GIM 86. Abstracts. 1986. p.185.

ZHENG, Y.; XU, X.; ZHANG, T. Interspecific transfer and expression of SQP1 plasmid of Streptomyces gingfengmyceticus, Acta Genetica Sinica, q: 423-430, 1982 . 
ZHUANG, Z.; TAN, H.; XU, Y.; ZHU, Y.; XUE, Y. A study on transformation of Streptomyces griseus plasmid DNA. Acta Genetica Sinica, 7: 291-298, 1980. 